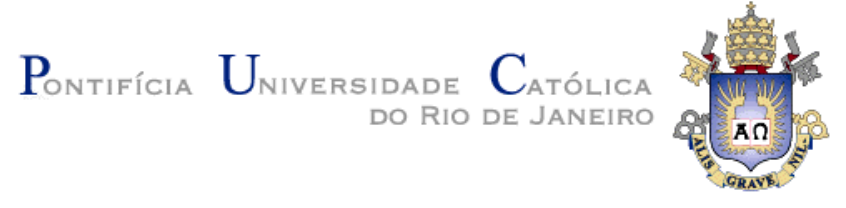

Bruna Figueiredo Gonçalves

\title{
A Governança Global da Terra: as iniciativas multilaterais para a regulação do fenômeno Land Grabbing
}

Dissertação de Mestrado

Dissertação apresentada como requisito parcial para obtenção do grau de Mestre pelo Programa de Pós-Graduação em Relações Internacionais do Instituto de Relações Internacionais da PUC-Rio. Aprovada pela Comissão Examinadora abaixo assinada.

Orientador: Prof. Luis Manuel Rebelo Fernandes

Co-orientadora: Prof. ${ }^{\text {a }}$ Ana Elisa Saggioro Garcia Muller

Rio de Janeiro

Julho de 2018 


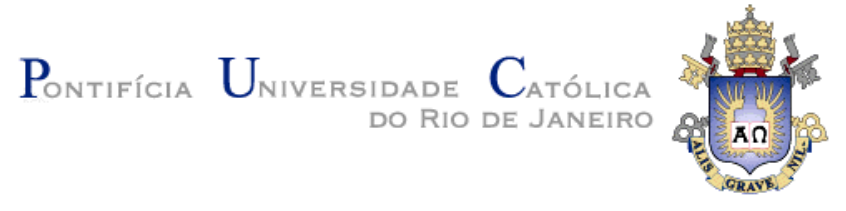

Bruna Figueiredo Gonçalves

\title{
A Governança Global da Terra: as iniciativas multilaterais para a regulação do fenômeno Land Grabbing
}

\begin{abstract}
Dissertação apresentada como requisito parcial para obtenção do título de Mestre pelo Programa de Pós-Graduação em Relações Internacionais do Instituto de Relações Internacionais da PUC-Rio. Aprovada pela Comissão Examinadora abaixo assinada.
\end{abstract}

Prof. Luis Manuel Rebelo Fernandes Orientador e Presidente Instituto de Relações Internacionais - PUC-Rio

Profa. Ana Elisa Saggioro Garcia Muller

Co-orientadora

UFRRJ

Profa. Andrea Ribeiro Hoffmann Instituto de Relações Internacionais - PUC-Rio

Prof. Sergio Pereira Leite

UFRRJ

Prof. Augusto Cesar Pinheiro da Silva

Vice-Decano de Pós-Graduação do Centro de Ciências Sociais - PUC-Rio

Rio de Janeiro, 13 de julho de 2018. 
Todos os direitos reservados. É proibida a reprodução total ou parcial do trabalho sem a autorização da universidade, da autora e do orientador.

\section{Bruna Figueiredo Gonçalves}

Graduou-se em Relações Internacionais pela Universidade Federal Rural do Rio de Janeiro em 2015. Possui interesse pelos temas Agricultura, Desenvolvimento e Economia Política Internacional.

Ficha Catalográfica

Gonçalves, Bruna Figueiredo
\[ \text { A governança global da terra : as iniciativas multilaterais } \]
para a regulação do fenômeno Land Grabbing / Bruna
Figueiredo Gonçalves ; orientador: Luis Manuel Rebelo
Fernandes ; co-orientadora: Ana Elisa Saggioro Garcia Muller.
- 2018.

136 f. : il. color. ; $30 \mathrm{~cm}$

Dissertação (mestrado)-Pontifícia Universidade Católica do Rio de Janeiro, Instituto de Relações Internacionais, 2018.

Inclui bibliografia

1. Relações Internacionais - Teses. 2. Land grabbing. 3. Governança global. 4. Organizações internacionais. 5. Terra. 6. Economia Política Internacional. I. Fernandes, Luis Manuel Rebelo. II. Garcia, Ana E. Saggioro. III. Pontifícia Universidade Católica do Rio de Janeiro. Instituto de Relações Internacionais. IV. Título. 


\section{Agradecimentos}

Aos meus professores, que contribuíram para a elaboração deste trabalho e que se tornaram essenciais para a minha formação ao longo do mestrado. Ao professor Luis Manuel Fernandes, pela orientação da pesquisa, pelos ensinamentos e inspiração proporcionados. À professora Ana Saggioro Garcia, co-orientadora da dissertação, pela disposição e encorajamento de sempre.

Aos demais professores e professoras do Instituto de Relações Internacionais da Pontifícia Universidade Católica do Rio de Janeiro (PUC-Rio) de quem tive o prazer de ser aluna durante o mestrado, com aulas e conversas ricas, que proporcionaram uma formação ampla e crítica: Bruno Magalhães, Isabel Siqueira, João Nogueira, Jimmy Casas Klausen, Maíra Siman, Marta Fernandez, Matt Davies e Roberto Yamato.

Às professoras Renata Summa e Geovana Zoccal Gomes, por terem me ajudado a dar meus primeiros passos na docência.

À turma do mestrado 2016.01 e aos amigos que pude fazer, que foram companheiros essenciais em todos os momentos desta trajetória.

À minha família, em especial, aos meus amados pais, Mariane e Mauro, pelo apoio emocional, financeiro e pelo amor, sempre.

Aos meus irmãos, Beatriz, Bernardo e Luciana, pelo carinho e companhia.

Ao Felipe, por todo apoio, ânimo, amor e paciência.

A todos os meus outros amigos que me ajudaram ao longo deste mestrado, direta ou indiretamente, pelo companheirismo, ânimo, paciência, afeto e os essenciais momentos de conforto e diversão.

Finalmente, à Pontifícia Universidade Católica do Rio de Janeiro (PUCRio), pela bolsa VRAC da Vice-Reitoria para Assuntos Comunitários, e à CAPES pelos auxílios concedidos, que me permitiram realizar este mestrado. 


\section{Resumo}

Gonçalves, Bruna Figueiredo; Fernandes, Luis Manuel Rebelo. A Governança Global da Terra: as iniciativas multilaterais para a regulação do fenômeno Land Grabbing. Rio de Janeiro, 2018. 136 p. Dissertação de Mestrado - Instituto de Relações Internacionais, Pontifícia Universidade Católica do Rio de Janeiro.

Os últimos anos têm presenciado um rápido aumento nos casos de land grab em diversas regiões do mundo. Terras e outros itens relacionados a ela têm sido apropriados em uma corrida global, que têm resultado em desapropriações, violações de direitos humanos, insegurança alimentar, dentre outros. O principal objetivo desta dissertação é analisar as iniciativas de organizações internacionais para a regulação global dos 'investimentos em terra' e discutir seus efeitos sobre o fenômeno land grabbing no início do século XXI. Para isso, o estudo busca, primeiramente, avançar na compreensão do land grabbing, entendido como apropriação de terras, ideia que está diretamente ligada aos processos paralelos de acumulação por espoliação e reprodução ampliada do capital, conforme conceitos de David Harvey, e a transformações recentes na economia e política mundiais, que contribuíram para a corrida contemporânea. Esta perspectiva é complementada pela teoria crítica neogramsciana das Relações Internacionais, que explicam como a governança global do período está entrelaçada a um modelo de desenvolvimento dominante. A governança global dos land grabs é analisada por meio do foco em duas iniciativas multilaterais, elaboradas pelo Banco Mundial e agências da ONU. Os conceitos de novo constitucionalismo e civilização de mercado são essenciais para notar como as organizações internacionais têm sido aliadas no processo de mercantilização da natureza, em uma governança pautada por um discurso neoliberal e coordenada pela disciplina de mercado e pelo poder político. Argumenta-se que tais organizações, por meio de suas iniciativas de governança da terra, legitimam as apropriações de terra e contribuem para uma despolitização do debate sobre land grabbing.

\section{Palavras-chave}

Land Grabbing; Governança Global; Organizações Internacionais; Terra; Economia Política Internacional. 


\section{Abstract}

Gonçalves, Bruna Figueiredo; Fernandes, Luis Manuel (Advisor). The Global Governance of Land: the multilateral initiatives to the regulation of the phenomenon land grabbing. Rio de Janeiro, 2018, $136 \mathrm{p}$. Dissertação de Mestrado - Instituto de Relações Internacionais, Pontifícia Universidade Católica do Rio de Janeiro.

Recent years have witnessed a rapid increase in 'land grabbing' in several regions of the world. Land and other related items have been appropriate in a global race whose dynamics have resulted in expropriations, human rights violations, food insecurity, among others. The main objective of this dissertation is to analyze the initiatives of international organizations for the global regulation of 'investments on land' and to discuss their effects on the land grabbing phenomenon at the beginning of the 21 st century. To this end, this study seeks firstly to advance the understanding of the land grabbing phenomenon, understood as 'appropriation of land', an idea that is directly linked to the parallel processes of accumulation by dispossession and reproduction of capital, according to David Harvey's concepts, and to recent transformations in world economy and politics, which contributed to the contemporary race. This perspective is complemented by assumptions and concepts of neogramscian critical theory of International Relations, which explain how the global governance of the period is intertwined with a dominant development model. The global governance of the land grabs is analyzed by focusing on two multilateral initiatives, launched by the World Bank and UN agencies. The concepts of new constitutionalism and market civilization are essential to note how international organizations have been allied in the process of commodification of nature, in governance ruled by a neoliberal discourse and coordinated by market discipline and political power. It is argued that such organizations, through their land governance initiatives, legitimize land appropriations and contribute to depoliticizing the land grabbing debate.

\section{Keywords}

Land Grabbing; Global Governance; International Organizations; Land; International Political Economy. 


\section{Sumário}

1. Introdução

2. A corrida global por terras: definições, contextos e impulsos

20

2.1. O que é land grabbing? Debates e definições

20

2.2. Land grabbing como acumulação por espoliação e busca por acumulação de capital

2.2.1. Dimensões históricas: continuidades e rupturas da fase contemporânea

2.3. Convergência de múltiplas crises, financeirização e os interesses por trás da corrida por terras

2.3.1. As crises no capitalismo, financeirização da economia e a convergência de múltiplas crises

3. Governança Global e Land Grabbing

3.1. O conceito de governança global e as Relações Internacionais

3.2. Transformações recentes na política e economia mundiais

58

3.3. Teoria crítica neogramsciana e governança global

62

3.4. A terra e o land grabbing como tópicos na agenda de governança global

3.4.1. Territorialidade, terra e soberania dos Estados-nação

3.4.2. A neoliberalização da agricultura e a emergência de movimentos de resistência 
4. As iniciativas multilaterais para a governança de land grabbing

4.1 As iniciativas de governança dos investimentos em terra e itens relacionados

4.1.1. A iniciativa 'Principles for Responsible Agricultural Investment that Respects Rights, Livelihoods and Resources' (PRAI)

4.1.2. A iniciativa 'Voluntary Guidelines on the Responsible Governance of Tenure of Land, Fisheries and Forests in the Context of National Food Security' (VG)

4.2. Limitações das iniciativas de regulação voluntárias

4.3. A legitimação das apropriações de terras e a despolitização do debate

5. Considerações finais

6. Referências bibliográficas 


\section{Lista de figuras}

Figura 1. Mapa de calor global (intensidade) de investimentos presentes no Land Matrix (2000-2016)

Figura 2. Distribuição continental dos países alvos de investimentos (2000-2016)

Figura 3. Transações agrícolas transnacionais com contratos concluídos (2000-2016)

Figura 4. Intenção das Aquisições de Terras (2000-2016)

Figura 5. Intenções das Aquisições de Terras em agricultura por região (\% da área) (2000-2016) 


\section{Lista de tabelas}

Tabela 1 - Principais iniciativas globais de regulação de investimentos em agricultura

Tabela 2 - Tendência de posicionamento sobre como tratar os investimentos estrangeiros em terra 


\section{Abreviaturas e siglas}

BIRD - Banco Internacional para Reconstrução e Desenvolvimento

BRICS - Brasil, Rússia, Índia, China e África

CFS - Comitê de Segurança Alimentar Mundial

EUA - Estados Unidos da América

FAO - Organização das Nações Unidas para Alimentação e Agricultura

FMI - Fundo Monetário Internacional

ICARRD - Conferência Internacional em Reforma Agrária e Desenvolvimento Rural

IFAD - Fundo Internacional de Desenvolvimento Agrícola

MST - Movimento dos Trabalhadores Rurais Sem Terra

OMC - Organização Mundial do Comércio

ONG - Organização Não Governamental

ONU - Organização das Nações Unidas

PRAI - Principles for Responsible Agricultural Investment that Respects, Livelihoods, and Resources

PRI - Principles for Responsible Investment in Farmland

PRIAFS - Principles for Responsible Investment in Agriculture and Food Systems

TIAA-CREF - Associação de Seguros e Rendas Vitalícias de Professores Americanos

UNCTAD - Conferência das Nações Unidas sobre Comércio e Desenvolvimento

VG - Voluntary Guidelines on the Responsible Governance of Tenure of Land, Fisheries and Forests in the Context of National Food Security

WCARRD - Conferência Mundial em Reforma Agrária e Desenvolvimento Rural 
1.

\section{Introdução}

O início do século XXI tem presenciado um rápido aumento nos casos de land grabbing em diversas partes do mundo. Além de terras, outros recursos e atividades relacionados a ela têm sido apropriados em uma corrida global associada a transformações agrárias em termos de mudanças no uso e no significado de recursos naturais, como a terra, bem como a transformações na economia e política mundiais. A agricultura, em particular é um elemento chave para a compreensão de diversas dinâmicas do capitalismo global e do debate sobre desenvolvimento, sobretudo em países em desenvolvimento, como o Brasil, em que o valor da terra para a economia e sociedade é significativo. Apesar disso, as apropriações constituem temas ainda pouco estudados na disciplina de Relações Internacionais.

O crescimento significativo nas transações de terras em larga escala na última década chamou a atenção do mundo para um fenômeno que tinha alcance cada vez maior. Um relatório elaborado pela sociedade civil e lançado em 2008 pela Organização Não Governamental (ONG) GRAIN ${ }^{1}$ alertou o mundo sobre o processo mundial que ocorria, e alarmou sobre os potenciais impactos negativos do que chamou de "land grab". Estas preocupações sobre land grab alcançaram a mídia neste período com os protestos em Madagascar, que ocorriam contra o governo acusado de ter liberado 3,2 milhões de hectares de terra para a empresa Daewoo Logistics por 99 anos, em negociações denunciadas pela falta de transparência (TNI, 2013).

${ }^{1}$ GRAIN é uma organização não governamental que apoia pequenos agricultores e movimentos sociais nas suas lutas por um sistema alimentar controlado e baseado no respeito a biodiversidade. Ver https://www.grain.org/pages/organisation 
O tema ganhou diversas páginas na imprensa desde então, que noticia casos de conflitos e disputas no campo e alarma sobre a escassez de alimentos ou a compra de terras por estrangeiros ${ }^{2}$. Preocupações quanto às suas consequências reais e potenciais, em ações frequentemente cercadas por segredos e incertezas quanto a quem e a quantidade de terras e capital envolvidos, chamaram a atenção não só da imprensa, mas também de diversos acadêmicos, ativistas e outras organizações da sociedade civil, que se engajaram em entendê-la, a partir de diferentes posições e perspectivas teóricas. As práticas de land grab ecoam em todo o mundo em desenvolvimento, principal alvo das apropriações, e a motivação e interesse por esse tema decorrem, em grande parte, de seus impactos sociais, ambientais, políticos e econômicos nas várias regiões do mundo, associados a experiências de desapropriações, violência, exclusão social e outros.

As consequências reais e potenciais de casos de land grab reforçaram a demanda por uma governança desse fenômeno, por parte da sociedade civil global, de organizações multilaterais, camponeses e ainda outros. A terra começou a ganhar mais destaque no âmbito transnacional e foi incluída na agenda de governança global de diversas organizações. Nesse sentido, na última década, têm sido criadas diversas iniciativas para regular a nível global os "investimentos em larga escala" em terra e outros recursos. As organizações internacionais que têm tratado do tema são de naturezas diferentes, sendo algumas do âmbito econômico, como o G8 e o Banco Mundial, enquanto outras são organizações ligadas à agenda de desenvolvimento, como as Organizações das Nações Unidas e suas organizações satélites, como agências, fundos e comitês, em especial as ligadas a alimentos e agricultura, além de coalizões de atores do setor privado.

A presente dissertação se insere nessa temática buscando compreender os efeitos destas iniciativas multilaterais sobre os processos de land grab. Esta pesquisa optou pelo foco em duas iniciativas consideradas centrais para

${ }^{2}$ Para exemplos, ver SAUER, S.; BORRAS, S. JR. 'Land Grabbing' e 'Green Grabbing': Uma leitura da 'corrida na produção acadêmica' sobre a apropriação global de terras. Campoterritório: revista de geografia agrária, edição especial, p. 6-42, 2016. 
governança dos investimentos em terra: a iniciativa intitulada Principles for Responsible Agricultural Investment that Respects, Livelihoods, and Resources (PRAI), lançada em 2010 e elaborada sob a liderança do Banco Mundial, em parceria com a Organização das Nações Unidas para Agricultura e Alimentação (FAO), com a Conferência das Nações Unidas sobre Comércio e Desenvolvimento (UNCTAD, sigla em inglês) e com o Fundo Internacional de Desenvolvimento Agrícola (IFAD, sigla em inglês); e a iniciativa Voluntary Guidelines on the Responsible Governance of Tenure of Land, Fisheries and Forests in the Context of National Food Security (VG), elaborado pela FAO em 2012.

A complexidade do fenômeno land grabbing tem motivado diversos estudos, realizados a partir de diferentes perspectivas teóricas, que tocam em aspectos como segurança e soberania alimentar, energia, direitos humanos, economia política internacional, governança e outros. Apesar da crescente produção acadêmica sobre o tema, nota-se que diversas questões permanecem em debate, especialmente em relação à definição e à caracterização do próprio fenômeno, que são disputados por pesquisadores, ativistas e organizações internacionais que possuem diretrizes para o tema, entre outros, ponto a que este trabalho se dedica no primeiro capítulo.

Cabe ressaltar que diferentes atores envolvidos nestes processos, como grupos de indivíduos, sociedade civil, organizações internacionais, empresas e pesquisadores, tendem a usar termos diferentes para tratar do tema, o que está diretamente associado as suas posições com relação a este. Por um lado, investidores, alguns Estados e organizações internacionais tendem a tratar os land grabs como "investimentos em terra em larga escala", termo que, apesar de se propor neutro, contribui para uma despolitização do debate sobre o tema. Por outro lado, atores mais críticos, como organizações da sociedade civil de oposição ao fenômeno, acadêmicos e outros, se referem ao fenômeno por "land grabbing", com o intuito de resgatar os conflitos que o envolvem. Este debate representa um ponto chave para esta pesquisa, pois toca em parte importante do problema de pesquisa proposto. 
Assim, diante do disputado debate quanto à definição do fenômeno, o presente trabalho parte da contribuição de alguns autores da Economia Política Internacional para construir uma definição de land grabbing. Os land grabs são entendidos como como "apropriação de terras", em que o termo apropriação implica "na transferência de propriedade, de direitos de uso e do controle sobre recursos que foram propriedades pública ou privada" (Fairhead, Leach, \& Scoones, 2012, p. 238, tradução nossa). Apropriação está diretamente relacionado aos processos duais e inter-relacionados de reprodução ampliada do capital e acumulação por espoliação, conceituação de David Harvey (2004a).

A literatura sobre o tema land grabbing no período contemporâneo surgiu ao longo dos últimos anos, conforme surgiam denúncias e identificavam-se novos casos de apropriação de terras. Em ritmo acelerado, a literatura foi sendo construída majoritariamente por artigos científicos publicados em revistas nacionais e internacionais, cujas análises, em grande parte, centravam-se em questões pontuais sobre o tema, buscando compreender o que estava acontecendo, onde, quando, quem estava envolvido ou outros aspectos elementares. Identificase como reflexo desta bibliografia, construída rápida e essencialmente por artigos curtos, pouco aprofundamento teórico pelos autores. A revisão de literatura realizada nesta dissertação encontrou poucas obras que se dedicassem a refletir de maneira mais profunda sobre o fenômeno e raros trabalhos sobre os mecanismos de regulação dos land grabs.

Nota-se, ademais, a pouca atenção recebida pelo tema por parte de especialistas em Relações Internacionais, o que destaca a contribuição desta proposta para a literatura sobre o tema de forma geral. A teorização presente na disciplina quanto à participação das organizações internacionais sobre acontecimentos da política e economia mundial amplia o debate sobre o tema, ao mesmo tempo que este diálogo contribui para a ampliação da agenda de pesquisas da disciplina, ao trazer seus conceitos para pensar o tema agrário, ainda pouco presente na literatura deste campo de estudo. 
Diante disso, surge a necessidade de um estudo que vise compreender a entrada deste fenômeno na agenda de governança global a partir de lentes teóricas críticas e a partir de uma perspectiva histórica, considerando os processos e contradições políticas e econômicas mais amplos por trás do fenômeno e de suas regulações. Tanto land grabbing quanto a sua governança estão diretamente relacionados a processos históricos e transformações na ordem mundial nas últimas décadas, em termos políticos, econômicos, sociais e outros. Em vista disso, o recorte histórico desta pesquisa compreende o período de 1970 até os dias de hoje. Ainda que a história do mundo seja marcada por land grabs, centrais em diversos processos da economia internacional, a análise do fenômeno em sua fase contemporânea permite observar que particularidades deste período são fundamentais para compreender processos históricos, transformações estruturais e outras que possibilitaram o fenômeno, a sua intensidade, a participação dos atores envolvidos e ainda outros pontos. A intensificação nas apropriações ocorre em um contexto de capitalismo avançado e economias globalizadas que tornam, dentre outras coisas, estas dinâmicas particulares em relação a períodos anteriores em que ocorreram.

O principal objetivo deste trabalho é analisar as iniciativas de organizações internacionais para a regulação global das apropriações de terra e discutir os efeitos desta governança sobre o fenômeno land grabbing no início do século XXI. A hipótese inicial deste trabalho é que as iniciativas de governança global sobre terra contribuem para a legitimação de um modelo de desenvolvimento que privilegia os interesses do capital. Apesar de considerarem que os investimentos em terra possuem riscos para os locais e populações em que ocorrem, estes são associados a fluxos inevitáveis da economia mundial e são defendidos como oportunidades de desenvolvimento essenciais, sobretudo para a garantia da segurança alimentar do mundo. Esta pesquisa mostrou que, além desta resposta inicial, o tratamento oferecido por estas organizações aos investimentos contribui para uma despolitização dos land grabs.

Para responder esta questão central, este trabalho parte de uma perspectiva que busca, primeiramente, explicar e definir o fenômeno através da compreensão 
de dinâmicas do capitalismo na busca pela acumulação de capital e que localiza o fenômeno em um contexto mais amplo de transformações na economia e na política marcadas pela globalização. Isto permite compreender as dinâmicas que este fenômeno envolve e, acima de tudo, as que o impulsionam. Tal perspectiva é inspirada em abordagens de autores da Economia Política Internacional, como David Harvey e Saskia Sassen, que contribuem para alcançar o objetivo específico de compreender o fenômeno sobre ao qual este trabalho se dedica, como perseguido no primeiro capítulo. Para alcançar o seu objetivo principal, esta dissertação se apoia sobre as contribuições da teoria crítica neogramsciana, sobretudo sobre obras do autor Stephen Gill, que analisa criticamente a governança global no período contemporâneo. Os conceitos de civilização de mercado e novo constitucionalismo, em especial, conformam o esquema teórico da dissertação para uma compreensão crítica da governança global.

A metodologia desta dissertação tem como base os pressupostos da teoria crítica neogramsciana, que preocupa-se com como os fatos surgem e em que contextos históricos e sociais ocorrem. Robert Cox parte da premissa de que "teoria é sempre para alguém e para algum propósito", desse modo, que uma teoria é sempre feita a partir de uma determinada perspectiva, que está localizada em certo tempo e espaço (COX, 1981, p. 128). Dessa forma, todo conhecimento refletirá particularidades de quem o produz, e das quais o teórico não pode se pensar imune. Cox ressalta a importância de se conhecer o contexto em que uma teoria é gerada e aplicada e o seu objetivo ${ }^{3}$.

Há por parte da teoria crítica a preocupação com como os fatos surgem e em que contextos históricos e sociais ocorrem. Os fatos são vistos como produtos de

${ }^{3}$ A necessidade de conhecer esses propósitos leva Robert Cox (1981) a fazer uma distinção entre teorias, dividindo-as entre "teorias de solução de problema" e "teoria crítica". Cox se refere às teorias positivistas como "teorias de solução de problemas", cujos propósitos seriam simplesmente ser um guia para a solução de problemas dentro de uma estrutura previamente estabelecida, visando seu melhor funcionamento. A busca pela solução para problemas específicos tende a colaborar com a manutenção da ordem vigente, ou seja, com a manutenção das instituições políticas e sociais. Ao não questionarem o contexto em que os fatos ocorrem, estas teorias podem ser compreendidas como uteis aos interesses dos que estão confortáveis com tal ordem, ou seja, às forças sociais dominantes que visam assim manter-se. 
estruturas sociais e históricas específicas, e não como verdades eternas. A teoria seria a abertura para a possibilidade de se emancipar e de olhar por perspectivas alternativas, que transcendem a realidade, segundo Cox (1981). Os conceitos e pressupostos da teoria crítica são resgatados como forma de compreender como determinados organismos internacionais têm tratado land grabbing. A partir de tais pressupostos, busca-se analisar os documentos elaborados por tais e refletir sobre como estes foram construídos, em que contexto, as bases teóricas sobre as quais se apoiam e os interesses em jogo.

A elaboração desta dissertação foi feita a partir da consulta de dois tipos de fontes. Em primeiro lugar, foi feita uma pesquisa bibliográfica com fontes secundárias, como livros, artigos acadêmicos e material jornalístico, com o objetivo de compreender as categorias teóricas e conceitos que proverão as bases para este estudo, bem como a interpretação de outros autores presentes em livros, artigos acadêmicos e periódicos que tratam dos diversos aspectos sobre land grabbing considerados. Essas fontes fornecem dados históricos e reflexões importantes para este trabalho. Em seguida, foram utilizadas fontes primárias, como documentos e relatórios das organizações internacionais selecionadas para a análise da governança dos investimentos em terra, sejam estas agências da Organização das Nações Unidas (ONU) e o Banco Mundial.

As reflexões teóricas e análises de documentos, que visam responder a questão central deste trabalho, foram organizadas e apresentadas em três capítulos, além desta introdução à dissertação, que visa apresentar os principais elementos desta pesquisa, e as considerações finais. $\mathrm{O}$ primeiro capítulo substantivo tem como finalidade apresentar e discutir os principais debates em torno do fenômeno land grabbing e o marco teórico que sustentou a compreensão deste trabalho sobre o que é o fenômeno. O capítulo é composto pela apresentação de conceitos e argumentos chaves de autores da Economia Política Internacional, que possibilitam pensar como estas práticas estão associadas a dinâmicas inerentes ao sistema capitalista e a particularidades históricas do período contemporâneo; questionar em que contextos históricos estas dinâmicas surgiram; e quais processos tornaram esse fenômeno possível. No segundo capítulo 
substantivo, discute-se brevemente o conceito de governança global e como land grabbing entrou na agenda global. O propósito do capítulo é apresentar e desenvolver conceitos e pressupostos da teoria crítica neogramsciana, afim de se refletir sobre o que transformações do ponto de vista do capitalismo neoliberal representam para a governança global do fenômeno em consideração. Entende-se que devem ser observados os agentes propulsores dessas mudanças na ordem, assim como os interesses que os motivaram e as estratégias utilizadas para garanti-los, partindo-se dos pressupostos da teoria crítica. Por fim, o último capítulo tem como propósito analisar os documentos elaborados para regular investimentos em terra e pensar como este tema tem sido tratado na agenda de governança destas organizações, em particular pelo Banco Mundial e pelas agências do sistema ONU. Os pressupostos e conceitos da teoria crítica são fundamentais para esta análise, que visa descortinar os conflitos escondidos por trás das iniciativas de regulação global de land grabbing e notar os efeitos deste tratamento para o debate sobre o fenômeno.

Em suma, este trabalho nasceu do desejo de aprofundar a compreensão sobre o tratamento dado por organizações internacionais aos investimentos em terra e recursos relacionados, assim, ao fenômeno land grabbing, por meio de suas inciativas multilaterais para regulação. A construção dos capítulos busca alcançar objetivos específicos, que contribuem para responder a questão central expressa acima. A conclusão deste trabalho aponta para o efeito legitimador das iniciativas para a regulação dos investimentos em terra, elaboradas pelas organizações internacionais analisadas, sobre os land grabs, e a contribuição destas iniciativas para uma despolitização sobre as apropriações de terra. 
2.

\section{A corrida global por terras: definições, contextos e impulsos}

Os últimos anos têm presenciado, conforme mencionado na introdução à dissertação, um crescimento significativo nos casos de apropriação de grandes parcelas de terra em diversas regiões do mundo, processo a que este trabalho se refere como land grabbing. O presente capítulo busca refletir sobre determinados aspectos deste processo, que possibilitam a compreensão do fenômeno em análise, objetivo específico desta dissertação. Nota-se que há um amplo debate na literatura dedicada ao tema quanto à definição e à caracterização do próprio fenômeno. Em vista disso, em primeiro lugar, propõe-se o debate sobre alguns de tais aspectos, relacionados ao que está ocorrendo e à forma como está ocorrendo.

Em seguida, este capítulo busca desenvolver a base teórica que sustenta a definição deste termo. Busca-se explica-lo e defini-lo através da compreensão de dinâmicas do capitalismo na busca pela acumulação de capital, e, a partir das lentes de autores da Economia Política Internacional, localiza-se o fenômeno em um contexto mais amplo de transformações na economia e na política. Por isso, por fim, este capítulo reflete sobre o fenômeno em perspectiva histórica, de modo a notar como processos anteriores à atual onda, mas também processos históricos e acontecimentos contemporâneos, contribuíram para sua fase atual.

\section{1.}

\section{O que é land grabbing? Debates e definições}

Os processos dos quais a presente dissertação se ocupa envolvem dinâmicas complexas, que podem ocorrer por uma pluralidade de formas e envolver diversos atores. Por meio de pesquisa bibliográfica sobre o tema, identificou-se que estes termos do debate não são um consenso, mas que, ao contrário, sua literatura é marcada por disputas por diversos pesquisadores, ativistas, organizações 
internacionais e outros atores quanto ao que é o land grabbing e quanto às suas características determinantes. Os debates têm se dedicado frequentemente a discutir questões como a quantidade de terras e capital envolvidos nas transações, a natureza das transações, isto é, se ocorrem por vias econômicas ou extra econômicas, e ainda sobre quem está envolvido, como por exemplo, indivíduos, empresas ou governos, e se estes devem ser exclusivamente nacionais ou estrangeiros, entre outros aspectos. Nesse sentido, as seções que seguem buscam refletir sobre algumas questões importantes presentes em tal literatura, como forma de contribuir para o debate sobre definição do que é land grabbing e definir como este será pensado ao longo da dissertação.

De início, cabe observar que até mesmo o termo utilizado para se referir a este fenômeno é alvo de controvérsia. Não há consenso na literatura quanto a tradução para o português dos termos utilizados, de modo que diferentes autores traduzem o termo "land grabbing" para variadas expressões e termos, que variam não só de idiomas, mas também de significados. Dentre as possíveis traduções para o português encontradas na literatura, está o termo "grilagem de terras", que entende-se não corresponder exatamente ao processo em questão. Em português, grilagem de terras refere-se à apropriação ilegal de propriedades públicas, enquanto land grabbing envolve também apropriações de propriedades privadas e por mecanismos legais (SAUER e BORRAS JR., 2016).

Há ainda autores que entendem land grabbing como sinônimo de "estrangeirização de terras", isto é, como transações de terras feitas necessariamente por atores estrangeiros em território nacional. Neste trabalho, defende-se que a estrangeirização de terras nacionais é uma dimensão importante de land grabbing e uma das mais controversas, posto que envolvem questões importantes como a soberania nacional dos Estados. Porém, corrobora-se a ideia de Borras et al. (2012) de que estes fenômenos não são sinônimos. Conforme esses autores, entender o fenômeno como estrangeirização resulta em uma compreensão limitada deste processo atual de corrida por terras, cuja complexidade envolve não apenas a apropriação de terras por estrangeiros. Assim, apesar de frequentemente estas práticas envolverem a estrangeirização de terras, a 
estrangeirização de terras não necessariamente requer ou resulta em land grabbing. Ao mesmo tempo, land grabbing não requer a participação de atores ou capitais estrangeiros para ser caracterizado, mas pode ser exclusivamente conduzido por atores nacionais, como indivíduos ou empresas nacionais.

Identifica-se também disputas na literatura sobre o termo utilizado para se referir ao fenômeno, pois diferentes termos refletem diferentes posições ideológicas e formas como tal é entendido. O termo "land grabbing" tem sido empregado normalmente por perspectivas críticas a estas práticas, que consideram as consequências políticas que estas possuem, enquanto outros termos como "aquisição de terra em larga escala" ou "investimentos em terra em larga escala" estão longe de serem neutros, como muitos autores propõem, mas tem um papel discursivo que despolitiza o fenômeno (MARGULIS, MCKEON e BORRAS JR., 2013). Diferentes atores envolvidos nestes processos, como grupos de indivíduos, sociedade civil, organizações internacionais, empresas e pesquisadores, tendem a usar termos diferentes para tratar do tema, o que está diretamente associado a suas posições com relação a estes investimentos.

Em geral, o fenômeno suscita o debate quanto aos seus aspectos positivos e negativos. A defesa dos land grabs tende a tratá-los como investimentos de grande escala em terra, que representam uma oportunidade para desenvolvimento econômico, positiva aos países que as recebem. Esta abordagem remete a investidores, corporações transnacionais, certas organizações internacionais e Estados e estudiosos mais otimistas, que reconhecem os potenciais riscos dos investimentos em terra e defendem que estes devem ser minimizados, mas o defendem pelo valor do retorno econômico do que se referem como “investimentos em terra em larga escala”. Este debate será retomado ao longo dos próximos capítulos.

Diversas abordagens entendem que os land grabs constituem ameaças, por receio às suas potenciais consequências. Esta visão se fundamenta em experiências passadas de desapropriações, violência e exclusão social como consequências de land grabs, além de outras consequências potenciais, como 
indicam Margulis, McKeon e Borras (2013), de maneira geral, ligadas a organizações da sociedade civil de oposição ao fenômeno, como a GRAIN mencionada anteriormente, que se referem ao fenômeno por "land grabbing". A autora Saskia Sassen (2016) afirma que as principais consequências dos investimentos são o grande número de micro expulsões de pequenos agricultores e cidades inteiras; níveis crescentes de toxidades na terra e na água; a expulsão de floras e faunas para dar lugar a monoculturas; fome em regiões que se produz, por exemplo, soja ao invés de feijão e outros alimentos. Este trabalho defende, entretanto, que olhar para estas abordagens em termos de vantagens e desvantagens dos "investimentos" pode limitar as possibilidades de mudanças destes processos, assumindo-se que estes investimentos são inevitáveis. Este ponto será retomado ao longo do texto.

Apesar da comprovação desta corrida global por terras e das transações de terras realizadas em diversas regiões do mundo ser difícil de ser feita, existe um relativo consenso de que estas estejam ocorrendo. Estas transações estão frequentemente 'cercadas de segredos' (WHITE, BORRAS JR., et al., 2012), relacionados não só a quem está envolvido, como também a quantidade de terras e capital envolvido. A escassez de dados confiáveis sobre este fenômeno representa um dos maiores dilemas dos pesquisadores e tomadores de decisão sobre o tema.

Em uma tentativa de contornar esta dificuldade e poder evidenciar o fenômeno, nos anos recentes foram criados diversos institutos e plataformas de pesquisa e de dados sobre land grabbing. Os dados disponibilizados pelas organizações GRAIN e Land Matrix ${ }^{4}$ se destacam como os mais utilizados pelos pesquisadores em suas pesquisas. Porém, deve-se observar que os dados quantitativos encontrados por estas bases possuem fragilidades, reconhecidas pelas próprias organizações em seus relatórios e websites. Tais fragilidades advêm primordialmente das fontes de informação que estes utilizam, que são

${ }^{4}$ A Land Matrix é uma iniciativa global e independente de monitoramento da terra, cujo objetivo é disponibilizar dados abertos a comunidade sobre investimentos em terra, afim de promover transparência e responsabilidade em tais. Ver <http://www.landmatrix.org/en/about/>. 
majoritariamente relatos de mídias e denúncias recebidas de ativistas e pesquisadores, e, logo, podem não ser fatos válidos. Conforme defendido por Carlos Oya (2013), os dados quantitativos disponibilizados por estas plataformas devem ser usados com cautela em pesquisas, e não devem ser usados como se fossem absolutos e conferissem rigor científico a estas.

Os institutos de pesquisa mencionados que se dedicam às apropriações de terra possuem diferenças entre si, como quanto à definição do fenômeno e à metodologia utilizada, que se refletem na diferença entre os dados disponibilizados por estes. O Land Matrix entende que land grabbing diz respeito a aquisições de terras através de compra, arrendamento ou concessão, feitas para a produção agrícola, extração de madeira, comércio de carbono, indústria, produção de energia renovável, conservação e turismo em países de baixa e média renda. As transações são consideradas pela plataforma desde que cumpram os seguintes critérios: as transações devem envolver a transferência de direitos de uso, controle ou propriedade de terra por meio de venda, arrendamento ou concessão; devem ter sido iniciadas a partir de 2000; cubram uma área de 200 hectares ou mais; e que impliquem no potencial uso de terras, que eram destinadas a produção de pequenos produtores, uso da comunidade local ou importantes para o ecossistema, em terras para fins comerciais (LAND MATRIX, 2018).

A GRAIN, por sua vez, adota um posicionamento político mais explícito de contraposição ao land grabbing. Em seus relatórios considera apenas as transações de terra que foram iniciadas após 2006, que não foram canceladas, que são lideradas por investidores estrangeiros, voltadas para a produção de culturas alimentares e que envolvem grandes áreas, superiores a 500 hectares de terra (GRAIN, 2016). Grande parte das diferenças entre os dados quantitativos disponibilizados por estas organizações está relacionada às definições do fenômeno adotadas por estas.

Nota-se que a definição desta última organização é bem mais restrita e compreende um período menor de tempo. Desse modo, enquanto o Land Matrix 
reporta $1528^{5}$ casos de land grab, que correspondem a 50.572.213 hectares de terra, entre 2000 e 2018, a GRAIN reporta 491 casos, cobrindo uma área de 30.000.000 hectares entre 2006 e 2016 (GRAIN, 2016). Estes dados não podem ser vistos como absolutos, como mencionado, mas permitem perceber que o número de casos segue crescendo ao longo dos anos.

Estes argumentos apontam para a importância de se discutir a definição e caracterização dos land grabs, como forma de contribuir para o debate, mas também para delimitar os termos desta pesquisa. Diante do exposto, defende-se a importância de uma definição do fenômeno centrada nas bases teóricas deste estudo, que considere as razões políticas, sociais e econômicas para que ocorra, mas também as implicações nestes âmbitos que possui. Esta definição será essencial para a análise crítica dos processos envolvidos.

Esta dissertação se esforça em construir uma definição de land grabbing a partir das contribuições de alguns estudiosos do tema, especialmente dos autores Fairhead et al. (2012) e Borras et al. (2012), conectando-as às formulações teóricas de David Harvey. Os primeiros definem land grabbing como "apropriação de terras", em que o termo apropriação implica "na transferência de propriedade, de direitos de uso e do controle sobre recursos que foram propriedades pública ou privada" (Fairhead, Leach, \& Scoones, 2012, p. 238, tradução nossa). Há dois aspectos, intimamente entrelaçados, que merecem atenção nesta definição.

O primeiro ponto é que esta definição ressalta que o fenômeno envolve não só a transferência de títulos de propriedade, e permite notar as diferentes formas pelos quais land grabs acontecem, como compra, arrendamento, contratos, conservação de florestas e outros, e não só em termos de compra de terras, ainda que esta seja uma das faces do fenômeno que mais ganha destaque na literatura e

${ }^{5} \mathrm{O}$ número de casos reportados varia a todo instante no website da Land Matrix. O valor citado refere-se ao acesso da plataforma, disponível em <http://www.landmatrix.org/en/>, em 26 mar. 2018. 
que mais gera resistência. Devido a isso, Borras et al. (2012) defendem que o fenômeno não seja entendido apenas em termos de escala de terras, mas também em termos de escala de capital.

O segundo ponto, que se conecta ao primeiro, refere-se à ideia de ver o fenômeno como "control grabbing", isto é, como o poder de controlar terra e outros recursos associados a ela, com vistas a se beneficiar deste controle (BORRAS JR., KAY, et al., 2012). Land grabbing envolve frequentemente mudança no significado e propósito da terra e dos recursos associados a ela, cujos novos usos ficam condicionados às necessidades de acumulação de capital que os controlam. Assim, esta definição possibilita pensar não só em "land grabs" (apropriação de terras, em tradução livre), mas também em "water grabs" e "green grabs", termos que têm se tornado cada mais frequentes na literatura para indicar apropriação de água e apropriação verde (em tradução livre), respectivamente (BORRAS JR., KAY, et al., 2012).

Além disso, Fairhead et al. (2012) defendem ainda que apropriação está diretamente relacionada aos processos duais e inter-relacionados de reprodução e espoliação (FAIRHEAD, LEACH e SCOONES, 2012). Essas noções estão relacionadas a teoria de David Harvey (2004b), que defende que a reprodução ampliada de capital é acompanhada pelo que chama de processos de acumulação por espoliação. Argumenta-se que land grabbing pode ser entendido pela perspectiva de Harvey, que se manifesta de ambas as formas.

Harvey (2014) defende que há dois modos de apropriação privada e acumulação de riqueza relevantes nos dias de hoje, que possuem relação simbiótica: a primeira são atividades que hoje seriam consideradas como extralegais e envolvem furto, roubo, corrupção, violência, coerção e outras práticas suspeitas e obscuras do mercado, como monopolização, manipulação, fixação de preços e outros; e a segunda são mecanismos legais de acumulação de riqueza, não coercitivos.

Nesse sentido, land grabbing pode ser simples acumulação de capital, em que os lucros acumulados são reinvestidos, aumentando o capital e a concentração 
de sua propriedade, ou pode ser acumulação primitiva, em que há expulsão ou redução de direitos de um proletariado que é separado da terra e da natureza, e as propriedades são liberadas para o capital privado. $\mathrm{O}$ conceito de acumulação por espoliação é uma releitura deste processo de acumulação primitiva descrito por Karl Marx ${ }^{6}$, que destaca a continuidade destes processos ao longo do desenvolvimento capitalista até os dias de hoje, fundamentais para acumulação de capital na contemporaneidade. Para compreender este processo, propõe-se refletir na seção seguinte sobre o processo de mercantilização da terra, em especial a partir da teoria do O Novo Imperialismo, de David Harvey.

\section{2.}

\section{Land grabbing como acumulação por espoliação e busca por acumulação de capital}

O argumento de David Harvey central para refletir sobre land grabbing nesta seção é que o processo de reprodução ampliada de capital é acompanhado pelo que o autor chama de processos de acumulação por espoliação (2004b). Esses dois processos estão relacionados à expansão do capitalismo e à globalização neoliberal das últimas décadas e permitem não só a compreensão de como ocorre land grabbing, mas também possibilitam compreender as raízes históricas dos processos que levaram a onda recente destas práticas, que estão ligadas a transformações mais amplas na ordem mundial nos últimos anos.

Os argumentos de Harvey são desenvolvidos a partir da tese central de Rosa Luxemburgo em A Acumulação do Capital: Estudo sobre a Interpretação Econômica do Imperialismo e de diversas ideias de Karl Marx. Luxemburgo

${ }^{6}$ Ver MARX, K. O Capital: Crítica da Economia Política. São Paulo: Editora Nova Cultural, 1996. 
(1970) defende que as recorrentes crises do capitalismo podem ser explicadas por um subconsumo ou uma falta de demanda efetiva suficiente para absorver a produção capitalista. Isto ocorre, pois, o capitalismo vive de absorver estruturas e formações não capitalistas como forma de realizar acumulação. Isto é, a condição vital para a acumulação capitalista é a desintegração e assimilação das formações pré-capitalistas, de algo "exterior" a si, um "outro", pelo qual o capitalismo se estabiliza (LUXEMBURGO, 1970).

O cerne da explicação para o imperialismo da autora é que este é uma fase da acumulação de capital ou fase da concorrência mundial do capitalismo, em que os Estados passam a buscar em outros lugares do mundo, em outros Estados, formações pré-capitalistas para que possam seguir acumulando capital. Uma vez que chega ao limite da expansão, se encontra o limite do movimento de acumulação, tornando-se impossível o desenvolvimento das forças produtivas e em decorrência surgiria a necessidade histórica objetiva de superar o capitalismo (LUXEMBURGO, 1970).

Por um lado, o autor discorda da perspectiva do subconsumo de Luxemburgo e defende que as recorrentes crises não são explicadas pelo subconsumo da sociedade, mas sim pela falta de oportunidades de investimentos lucrativos para absorver o capital excedente, o que chama de "sobreacumulação". Por outro lado, concorda com a ideia de Luxemburgo de que há algo "exterior" ao capitalismo necessário para sua estabilização. Porém, diferente desta autora, defende que este "exterior" pode ser tanto formações pré-existentes (formações não capitalistas ou setores do capitalismo ainda não proletarizado, como a Educação), quanto ser algum tipo de "exterior" que o capitalismo mesmo produza ativamente. Hannah Arendt já teria argumentos semelhantes a estes anos antes: ela explica o imperialismo inglês pela sobreacumulação de capital e o surgimento do dinheiro supérfluo que não encontravam mais oportunidade de investimento dentro das fronteiras nacionais na Inglaterra entre 1860 e 1870. Nesse processo, percebe-se que a acumulação primitiva, associada ao simples roubo, deveria se repetir ao longo da história do capitalismo, para que este não morresse, isto é, continuasse a acumular capital (ARENDT, 1998). 
Para refletir sobre esta dialética "interior-exterior", que seria necessária para a sobrevivência do capitalismo e a sua expansão contínua, Harvey propõe uma releitura do conceito de "acumulação primitiva" de Karl Marx. Ao recuperar os processos descritos por Marx como acumulação primitiva de capital, o autor sugere que estes permanecem presentes no capitalismo até hoje, de forma que vai além da proposta da Marx, que via estes processos como pertencentes a um período já acabado, original e não mais relevante, e além de Luxemburgo, que os via como alguma forma exterior ao capitalismo como sistema fechado. Harvey propõe, então, que a acumulação de capital baseada em atividades predatórias, fraudulentas e até violentas está presente de forma contínua no desenvolvimento do capitalismo. Este processo de acumulação ainda em andamento é chamado por ele de "acumulação por espoliação". Tanto a ideia de sobreacumulação, como a necessidade de algo exterior ao capitalismo para sua estabilização dão as bases para compreensão desta estratégia (HARVEY, 2004a).

Os conceitos de acumulação primitiva de Karl Marx e de acumulação por espoliação de David Harvey são usados por vários autores da literatura de land grabbing para analisar o fenômeno. Cabe ressaltar, entretanto, que estes conceitos são interpretados de formas diferentes por diversos autores e isto tem levado a diferentes análises sobre o fenômeno (HALL, 2013). A existência de um amplo debate sobre diferentes interpretações sobre estes conceitos torna necessário que este trabalho defina a forma como o entende, e, para isso, deve-se destacar uma diferença fundamental entre interpretações, que é importante para nossa pesquisa: em alguns trabalhos estes conceitos são usados como sinônimos, e, em outros, estes são vistos como processos diferentes.

Esta dissertação entende que ambos possuem diferenças que devem ser consideradas, que dizem respeito especialmente à ideia de continuidade presente em acumulação por espoliação. Alguns autores afirmam que este conceito, assim como o de acumulação primitiva de Marx, informa sobre a forma como relações sociais capitalistas são criadas e como pessoas e recursos que estavam fora do capitalismo são trazidos para dentro dele. De maneira parcialmente diferente, esta interpretação deste conceito ressalta tal ideia de continuidade presente neste, o que 
acontece dentro do próprio capitalismo. A acumulação original no fim da época medieval na Europa se fundamentou em violência, depredação, furto, fraude, roubo, que propiciou dinheiro inicial suficiente para começar a circular o dinheiro sob a forma de capital. Em seguida, meios legais foram adotados para reunir dinheiro pela espoliação e destruição das formas pré-capitalistas, como ao lotear terras comuns, por meio de práticas coloniais e imperialistas. Apesar de hoje o capital se realizar pelo reinvestimento do excedente criado no dia anterior, a acumulação violenta, como a praticada em tempos anteriores, ainda possui papel importante na reunião do poder de dinheiro inicial (HARVEY, 2011). A acumulação por espoliação é uma parte necessária para reprodução do capital e, dessa forma, não está associada somente a absorção do que está fora do capitalismo.

Para ressaltar a ideia de continuidade neste conceito, Harvey destaca diversos processos identificados por Marx como formas de acumulação primitiva, que seguem presentes no dia de hoje, como a "mercantilização e a privatização da terra, a expulsão violenta de populações camponesas, a conversão de várias formas de direitos de propriedade (comum, coletiva, do Estado etc.) em direitos exclusivos da propriedade privada" e outras (HARVEY, 2004a, p. 121). Populações camponesas têm sido expulsas de terras em diversas partes do mundo, recursos antes partilhados, como a água, têm sido privatizados e inseridos na lógica capitalista de acumulação, o agronegócio substituiu a agropecuária familiar e mais. Ao mesmo tempo, novas formas de acumulação por espoliação foram criadas nos últimos anos, como a biopirataria, a commodificação ou mercantilização da natureza de diversas formas (HARVEY, 2004a). Estes processos se conectam diretamente à forma como land grabbing tem ocorrido no período contemporâneo, como se pretende argumentar.

Harvey afirma que alguns dos mecanismos da acumulação primitiva destacados por Marx se aprimoraram e desempenham hoje um papel ainda mais forte. Determinadas características do capitalismo contemporâneo representam "grandes trampolins de predação, fraude e roubo", como o sistema de crédito e o capital financeiro (HARVEY, 2004a, p. 122). Além destes, cabe destacar, para o 
desenvolvimento desta pesquisa, ainda outros mecanismos predatórios e fraudulentos, como a financeirização, valorizações fraudulentas de ações, destruição de ativos pela inflação e dívidas que aprisionam indivíduos e países (HARVEY, 2004a).

Em definição, a acumulação por espoliação libera um conjunto de ativos (incluindo força de trabalho) a custo mais baixo (às vezes zero), de forma que o capital excedente pode se apropriar deste conjunto de ativos e dar-lhes um uso lucrativo. Dessa forma, o capital global excedente encontra, através da acumulação por espoliação, novos mercados para investir. A série de privatizações do final do século passado podem ser explicadas desta forma: bens coletivos são disponibilizados para o mercado para ser usado em algo mais lucrativo pelo capital excedente (HARVEY, 2004a).

O capital excedente também pode encontrar oportunidade de investimento através de "desvalorizações dos ativos de capital e da força de trabalho existentes". Com isso, "esses ativos desvalorizados podem ser vendidos a preço de banana e reciclados com lucro no circuito de circulação do capital pelo capital sobreacumulado" (HARVEY, 2004a, p. 124). Isto ocorre através de crises, que podem ser orquestradas, administradas e controladas. Esse mecanismo corresponde basicamente a programas de austeridades administrado por Estados, que possibilitam a transferência de propriedade de uns para outros, representando também formas de acumulação por espoliação. Taxas de juros e sistemas de créditos são centrais nesses processos, que podem ocorrer limitados a um setor, a um território ou a toda uma região, e, para isso, conta-se com o sistema financeiro internacional, liderado pelo Fundo Monetário Internacional (FMI) e pelo Estado "superior", os Estados Unidos. Desvalorizações e liberalizações financeiras impostas pelo FMI podem apontar para este caminho (HARVEY, 2004a).

Através de crises e desvalorizações, o capitalismo cria o seu próprio "outro" pelo qual irá se alimentar. Nesse processo, "valiosos ativos são tirados de circulação e desvalorizados. Ficam esvaziados até que o capital excedente faça uso deles a afim de dar nova vida à acumulação do capital" (HARVEY, 2004a, p. 
126). Dessa forma, Harvey entende que a acumulação por espoliação é uma saída sempre temporária do capitalismo para as sucessivas crises que enfrenta.

Este quadro teórico permite entender land grabbing em associação direta a processos de acumulação de capital por espoliação, em que terras são disponibilizadas no mercado e aparecem como nova oportunidade de investimento para o capital excedente, para receber uso lucrativo, como novo local de acumulação de capital. As terras são disponibilizadas para estes investidores de diversas maneiras, como desapropriações, privatizações e desvalorizações, como apontado por Harvey, que podem ocorrer de forma orquestrada, administradas e controladas pelos próprios Estados, de forma a possibilitar a transferência de propriedade de uns para outros. O capitalismo cria as próprias condições para manter acumulação de capital, em grande parte, com ajuda dos Estados. Harvey ressalta, assim, os casos de desapropriação de terras de populações de diversos locais como necessários para a expansão do capitalismo.

A apropriação de terras, em particular a apropriação de terras por estrangeiros, é parte da história da humanidade e não representa um fenômeno completamente novo. Porém, a apropriação de terras associada às dinâmicas de expansão do capital, conforme interpretação proposta de Harvey, assim como as relações políticas e sociais deste novo período, apontam para particularidades na fase contemporânea.

A ordem mundial nas últimas décadas sofreu transformações marcadas em particular pela globalização política e econômica neoliberal e ainda outros processos, como a financeirização da economia. Tais transformações foram acompanhadas do aumento dos processos de acumulação por espoliação, particularmente após 1973, período associado ao início do imperialismo neoliberal. Harvey destaca que a financeirização, a globalização e a política neoliberal tiveram papel fundamental para que houvesse esse aumento nas práticas de acumulações por espoliação e, assim, nos casos de land grabs.

O fortalecimento do sistema financeiro internacional neste período contribuiu com surtos de valorização que favorecem a acumulação por espoliação. 
A globalização neoliberal contribuiu para a abertura de novos territórios ao desenvolvimento capitalista e para um comércio internacional mais livre, além da política neoliberal que, por sua vez, teve peso ao informar as formas distintas como o Estado, sempre um grande agente da acumulação por espoliação, deveria se desenvolver. A política internacional neoliberal de privatização, representa um dos principais fatores que favoreceram o aumento na acumulação por espoliação desde então. Este é o cerne do fenômeno chamado por Harvey de "novo imperialismo", em que por meio de ajustes espaço-temporais necessários para a absorção de excedentes de capital, este se expande para além das fronteiras nacionais, dada a incapacidade de descobrir soluções internamente para a sobreacumulação, e buscam em outros países oportunidades de investimento do capital excedente, momento em que a liberalização da economia de diversos países no final do século XX, mediante pressões do FMI e da OMC, aparece como principal mecanismo que permitiu essas práticas (HARVEY, 2004a). A conversão neoliberal da governança global também deve ser observada.

Estes processos, porém, não se relacionam somente à dimensão da espoliação, mas sim a todas as formas com que a corrida por terras se expressa. A complexidade destes processos e suas implicações serão analisadas mais detalhadamente ao longo desta dissertação, como forma de compreender os contextos e processos históricos que tornaram possível o land grabbing no início do século XXI. A perspectiva de David Harvey dialoga diretamente com a Saskia Sassen, socióloga que tem se dedicado a compreender o fenômeno land grabbing no Sul global. Ambos os autores contribuem para a compreensão da conjuntura política e econômica que estabeleceu as condições ou teve impacto sobre o fenômeno em análise.

Saskia Sassen argumenta que os programas de reestruturação implementados pelo FMI e o Banco Mundial nos anos 1980 e 1990 tornaram possíveis, em grande parte, as aquisições de terras por estrangeiros hoje. Isto se deve, para a autora, tanto a objetivos explícitos destes programas, quanto a consequências não planejadas. As demandas da OMC na década de 1990 e início de 2000 para levantar as barreiras de importação e exportação em nome do livre 
comércio, que promovia a abertura de fronteiras nacionais, também contribuíram (SASSEN, 2016).

Estes programas incluíram a terra nos circuitos globais de acumulação de capital e são parte importante para a explicação das peculiaridades da fase atual de aumento de land grabbings em relação a períodos anteriores. Sassen argumenta que estes programas prepararam o terreno, em países do Sul global, para uma expansão do que entende como capitalismo avançado. Nesse processo, os territórios destes países passam a representar não Estados-nação, soberanos, mas sim recursos necessários para o sistema capitalista seguir acumulando capital, isto é, como espaço operacional para o capitalismo avançado se expandir (SASSEN, 2010); (SASSEN, 2016). A terra passa a ser cada vez mais demandada pelo capitalismo, levando a uma maior mercantilização e financeirização da terra, enquanto os próprios territórios nacionais são reposicionados como forma de atender estas demandas, vindas de empresas e governos nacionais e estrangeiros.

As limitações impostas e as demandas desses programas disciplinaram os governos que ainda não haviam se adequado e integrado aos regimes de livre comércio, representando normas para uma administração correta da economia destes países, caso desejassem crescimento e prosperidade. Sassen indica que, entre as normas mais conhecidas, estão o controle da inflação, pagamento da dívida e a privatização de serviços básicos. No entanto, o efeito obtido por estes programas foi contrário ao seu objetivo de promover o crescimento dos países, tendo resultado no aumento do endividamento dos países com relação aos credores estrangeiros e no encolhimento dos fundos governamentais para educação, saúde e infraestrutura (SASSEN, 2016).

Dessa forma, estes programas, além de atuar na abertura da economia destes países, levaram ao aumento de suas dívidas nas décadas de 1980 e 1990. As dinâmicas do endividamento gerado por estes programas são o ponto central para entender o papel destes programas sobre land grabbing hoje. Não somente a dívida em si é importante, mas também a forma como esta dívida é usada para reorganização da economia política. 
Estes programas são responsáveis, em parte, pela facilidade com que compradores estrangeiros podem adquirir terra em muitos países e pela facilidade com que governos desejam permitir essas aquisições. Estes efeitos estão relacionados ao papel disciplinador do regime da dívida. Por um lado, o regime da dívida é entendido como fator de enfraquecimento e empobrecimento de governos nacionais em boa parte do Sul global, que gerou frequentemente corrupção extrema, negligência quanto ao bem-estar da população e maior disponibilidade do governo de um país para vender grandes quantidades de terra e/ou expulsar populações. Por outro lado, este regime funcionou como uma porta de acesso aos Estados soberanos, não só para o FMI e o Banco Mundial, mas agora também para governos e empresas estrangeiras. A grande reorganização fiscal deste período colocou como prioridade o pagamento da dívida externa em detrimento de investimentos no bem-estar populacional, em setores como saúde e educação, o que teve efeitos socioeconômicos em boa parte destes países. Isto funcionou como facilitador para a compra de terras por estrangeiros (SASSEN, 2013); (SASSEN, 2016).

Assim, Sassen defende que países enfraquecidos e corruptos, com população com pouca voz e representação política, se tornam locais mais fáceis de se comprar terra para países e investidores ricos. Esses programas são muito mais do que apenas o pagamento da dívida gerada, são uma forma de moldar uma economia política e reposicionar aqueles como lugares de extração de recursos naturais. A primazia dessa lógica de exploração em grande parte não foi intencional, mas contribui para a devastação de grandes setores das economias tradicionais e empobrecimento do Estado e sua população, dentre outras consequências.

\subsection{1.}

\section{Dimensões históricas: continuidades e rupturas da fase contemporânea}


A história do mundo é marcada por land grabs. As práticas de land grab hoje são vistas por diversos autores como práticas que se assemelham a outras épocas históricas, mas que também possuem diferenças dessas épocas quanto a vários aspectos. A tendência à ênfase nas diferenças entre diferentes tempos pode tornar mais difícil notar as continuidades existentes entre tais ou até as disfarçam, o que requer atenção. Todavia, é necessário reconhecer que há particularidades na fase contemporânea desse fenômeno, como a financeirização, que contribui para o aumento de interesse por terras e representa novas formas pelas quais os "investimentos" que resultam em expulsão ou outras formas acontecem.

Determinados aspectos como a lógica geopolítica ou a legalidade das práticas contribuem para esta reflexão. No período em que havia um colonialismo formal, os land grabs eram feitos primariamente pelos países do Norte global em países do Sul global, com o objetivo de expandir suas riquezas e impérios. Dominavam, assim, relações centro-periferia, que facilitavam a transferência de riquezas das colônias para favorecimento dos interesses dos impérios. Com o fim da Segunda Guerra Mundial, o colonialismo formal começa a desaparecer, e a forma como land grabbing ocorre hoje se mostra mais complexa e policêntrica que a lógica centro-periferia consegue explicar, segundo Margulis \& Porter (2013).

Os dados disponibilizados pelo Land Matrix permitem observar os países envolvidos e os maiores fluxos de investimentos encontrados hoje. O alcance geográfico de land grabbing é um aspecto importante do fenômeno, não só para a discussão sobre sua governança global, mas para alguns aspectos políticos das transações de terra. Os casos de land grabs foram reportados em todos os cinco continentes do planeta. Os países do Sul global, conforme pode ser observado nas figuras abaixo, são os maiores alvos dos investimentos em terra. Porém, não é possível afirmar que prevalece sobre este fenômeno a tradicional lógica Norte-Sul de exploração, visto que determinados países que são alvo dos land grabs, são também, ao mesmo tempo, países que fazem land grabs. Este é o caso do Brasil, que é ao mesmo tempo um dos maiores investidores em terra e um dos países que mais recebe tais investimentos (LAND MATRIX, 2018). De forma geral, este 
processo está associado à emergência de novos atores na ordem global, como os BRICS, países em emergência que buscam mais poder sobre as regras internacionais, afim de governar inclusive a produção, distribuição e o consumo de alimentos e outras commodities (BORRAS, FRANCO e WANG, 2013).

Figura 1. Mapa de calor global (intensidade) de investimentos presentes no Land Matrix (2000-2016)

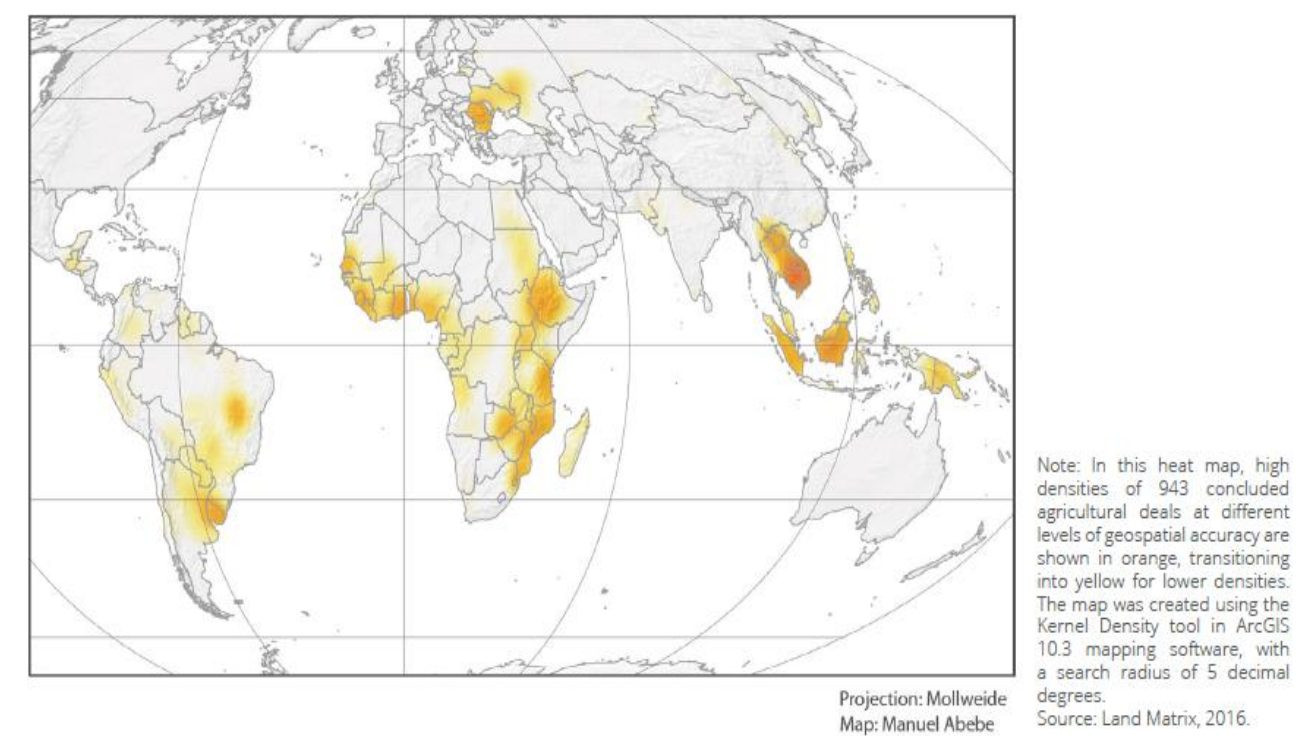

Fonte: Nolte, Chamberlain, Giger, Land Matrix Analytical Report, 2016.

Figura 2. Distribuição continental dos países alvos de investimentos (20002016)

\begin{tabular}{lcc} 
REGION & $\begin{array}{c}\text { NUMBER OF CONCLUDED DEALS } \\
\text { TOTAL SIZE OF CONCLUDED DEALS } \\
\text { (MILLION HECTARES) }\end{array}$ \\
\hline Africa & 422 & 10.0 \\
Eastern Europe & 96 & 5.1 \\
Asia & 305 & 4.9 \\
Latin America & 146 & 4.5 \\
Oceania & 35 & 2.2 \\
\hline Total & $\mathbf{1 0 0 4}$ & $\mathbf{2 6 . 7}$ \\
\hline
\end{tabular}

Source: Authors' calculation based on Land Matrix data, April 2016.

Fonte: Nolte, Chamberlain, Giger, Land Matrix Analytical Report, 2016. 
Margulis e Porter (2013) enfatizam as diferenças que existem entre a forma como estas práticas acontecem hoje em relação a outros países. Estes autores defendem que, por mais que diversos casos de land grabs, como os feitos por Chineses em países africanos, se assemelhem em determinados aspectos à era do imperialismo, não há hoje um controle formal colonial destes países, e, em outros países, a situação se mostra mais complexa. Além disso, afirmam que, no período contemporâneo, as lógicas de apropriação de terras são diferentes do período colonial, pois hoje a terra é negociada legalmente e não mais predominam aquisições por meios violentos e ilegais. Os autores reconhecem, entretanto, que há contestação quanto a legitimidade e a legalidade em muitas das transações de terras, visto que violências continuam a ocorrer, mas afirmam que a maior parte dos land grabs ocorre por práticas formais, como contratos, permitidas pelas práticas de governança de autoridades nacionais, subnacionais e atores econômicos transnacionais. A autora Saskia Sassen (2013), por sua vez, considera que a forma como land grabbing ocorre hoje se difere do período imperial, em que predominavam formas violentas de apropriação, dadas pela força, visto que hoje os mecanismos pelos quais as apropriações são feitas são investimento direto e compra ou leasing direto.

Este trabalho defende que existem particularidades na fase contemporânea, mas que há de se observar as continuidades existentes entre estes períodos históricos, e, que, ainda que não haja o controle formal sobre outros países, por exemplo, variadas práticas (de dominação ou exploração) deste período seguem presentes, se aprimoraram ou se manifestam sob novas formas. A partir do quadro teórico desta pesquisa, em particular as contribuições de David Harvey, defendese que determinadas práticas imperialistas seguem de forma contínua presente no desenvolvimento capitalista e representam uma parte significativa da forma como land grabbing ocorre hoje, assim como outras práticas conectadas à reprodução ampliada de capital. 
A definição de land grabbing desta pesquisa abarca diferentes mecanismos pelos quais o fenômeno ocorre, como compra, arrendamentos ou leasing, mas também a violência e fraude, mecanismos que possibilitam a tomada de controle das terras e outros recursos associados, exemplos de tais práticas. Cabe ressaltar que práticas imperialistas podem ocorrer tanto de maneira legal quanto ilegal, nos termos de Harvey, de forma que distinguir os dois períodos por este critério pode dificultar a análise.

Conforme explica Harvey, no capitalismo, a terra, elemento central nesta pesquisa, foi transformada em mercadoria, assim como trabalho e o dinheiro, por processos em que dominavam violência, roubos e outras formas de espoliação. Os cercamentos na Inglaterra, como descritos por Marx, assim como as práticas coloniais, em períodos anteriores, tiveram papel central em tornar o mercado de terras um campo primário de acumulação de capital. Hoje, estes processos, entendidos como acumulação por espoliação, representam práticas que foram fundacionais para a criação do capital, mas que nunca desapareceram. A economia baseada em espoliação está no cerne do que o capital é, fundamentalmente (Harvey, 2014).

No colonialismo, práticas de acumulação por violência, roubos, fraudes e outros eram centrais. No mundo hoje, tanto as políticas de espoliação para acesso à terra e outros recursos naturais, que seguem sendo importantes, quanto as aquisições realizadas para simples reprodução do capital, caracterizam a recente corrida por terras. Em seu recente livro Seventeen Contradictions and the End of Capitalism, Harvey reflete sobre os land grabs no mundo contemporâneo e defende que na África, América Latina e até mesmo Ásia, encontram-se os sintomas mais visíveis de como a política de acumulação por espoliação está viva e no centro do mundo capitalista (Harvey, 2014). Notar que parte da forma pela qual land grabs ocorrem hoje nunca desapareceram é essencial para compreender o fenômeno. Porém, a fase contemporânea desta corrida possui particularidades, que estão ligadas a processos e mudanças políticas e econômicas nos anos recentes, como será discutido na próxima seção. 


\section{3.}

\section{Convergência de múltiplas crises, financeirização e os interesses por trás da corrida por terras}

A fase contemporânea de land grabbing é marcada pelo rápido ritmo e intensidade com que os investimentos em terra têm acontecido. Entre os anos de 2006 e 2016 as transações agrícolas transnacionais cresceram exponencialmente, como mostra a figura abaixo, retirada do relatório mais recente do Land Matrix, que permite que se tenha uma dimensão deste crescimento ao longo dos últimos anos. Este significativo crescimento está associado a diversos e complexos eventos e transformações na economia e política mundial.

Figura 3. Transações agrícolas transnacionais com contratos concluídos (20002016)

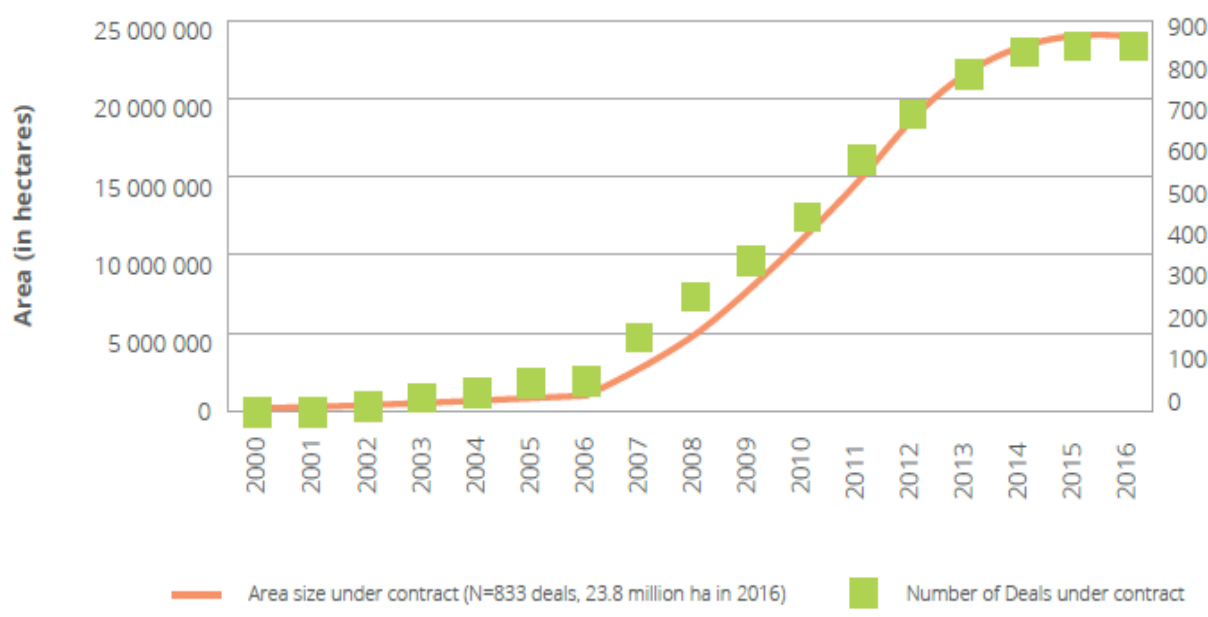


O objetivo desta seção é refletir sobre as forças endógenas e exógenas, que impulsionaram os investimentos em terra. Nota-se que diversos motivos são apontados, na literatura sobre o tema, como primordiais para o aumento de casos de land grabbing, como a financeirização da terra e de commodities, assim como a crise de alimentos de 2007-2008, entre outras crises. A convergência de múltiplas crises, no final da década de 2000, constitui a razão mais apontada pelos pesquisadores que se dedicam ao tema para o aumento nas transações em terra e agricultura e representa um fator distintivo da fase contemporânea no fenômeno. Tais múltiplas crises são: financeira, alimentar, energética e ambiental (WHITE, BORRAS JR., et al., 2012); (BORRAS JR., KAY, et al., 2012). As motivações para o crescimento nos casos de land grabbing relacionadas a tais crises são muitas e se entrelaçam de forma complexa entre si e com outros elementos, de modo que não se pretende neste trabalho esgotar as interpretações possíveis destes. Com vistas a analisar a forma como estas crises se relacionam a land grabbing, propõe-se primeiramente refletir sobre o que estas diversas crises representam no modo de produção vigente, o capitalismo.

\subsection{1.}

\section{As crises no capitalismo, financeirização da economia e a convergência de múltiplas crises}

O sistema capitalista é um sistema propenso a crises, mas que tem apresentado inovações ao longo da sua história para ultrapassá-las e expandir-se. Este é um sistema orientado à expansão e acumulação de capital, em que o capital não deve ser entendido como uma coisa, mas como um processo que tem por objetivo a perpetuação da acumulação (HARVEY, 2011). Essa incessante busca pela acumulação de capital leva ao que se entende como a principal contradição da lógica capitalista: a sobreacumulação. Nesse momento, o sistema capitalista não tem mais como produzir riquezas e multiplicar mercadorias, dinheiro e capital, pois a base a ser reproduzida torna-se excessiva. As crises são a 
manifestação do excesso de capital que não encontra oportunidades lucrativas para que possa seguir acumulando (BOTELHO, 2014).

Para atingir o objetivo de superar qualquer obstrução potencial à livre circulação de capital em todo o mercado mundial, o desempenho do capitalismo tem sido surpreendentemente criativo ao longo dos últimos duzentos anos, apresentando inovações em diversos setores da economia e nas relações com o Estado. O capital tem convertido limites aparentemente absolutos em barreiras que podem ser superadas ou contornadas, por meio de diversos mecanismos e ajustes (HARVEY, 2011).

Diante de crises de sobreacumulação, a expansão e a acumulação de capital são alimentadas por novos arranjos temporais e espaciais. A sobreacumulação supõe um excedente de trabalho e um excedente de capital. Esses excedentes devem ser absorvidos, conforme Harvey, por meio de dois ajustes: (a) o deslocamento temporal "através dos investimentos de capital em projetos de longo prazo ou gastos sociais (tais como educação e pesquisa), os quais jogam para o futuro a entrada em circulação dos excedentes de capital atual"; (b) e deslocamentos espaciais "através da abertura de novos mercados, novas capacidades produtivas e novas possibilidades de recursos e trabalho em outros lugares"; ou (c) alguma combinação de (a) e (b) (HARVEY, 2004b, p. 96, 97).

Harvey indica que tal ajuste é uma metáfora das soluções para as crises capitalistas de sobreacumulação através do adiamento do tempo e da expansão geográfica. Estes ajustes fornecem diversos modos de absorver os excedentes de capital e trabalho pela produção de espaço, pela organização de novas divisões territoriais do trabalho, pela abertura de novos e mais baratos complexos de recursos, pelos novos espaços de acumulação de capital e mais (HARVEY, 2004b). Cabe destacar particularmente os ajustes espaciais para pensar land grabbing. Se em determinado país há excedente de capital e de força de trabalho que não podem ser absorvidos, estes devem ser enviados a outro lugar para serem realizados e não serem desvalorizados. 
Nos ajustes espaciais feitos por diversos países, por meio da expansão geográfica, destacam-se não só a acumulação de capital através do reinvestimento do excedente obtido em transações anteriores, mas também o que Harvey chama de acumulação por espoliação, que representa uma importante forma de inovação do capital para sair da crise. Desse modo, a reprodução ampliada do capital caminha junto com a acumulação por espoliação, por mais que esta última tenha permanecido silenciada por um período no último século, aspecto que tem se alterado nos últimos anos.

A partir disso pode-se compreender a crise financeira que teve seu boom em 2007-2008 nos Estados Unidos da América e na Europa. As crises financeiras, como afirma Harvey, "servem para racionalizar as irracionalidades do capitalismo", levando a "reconfigurações, novos modelos de desenvolvimento, novos campos de investimento e novas formas de poder de classe" (HARVEY, 2011, p. 23). A crise de 2008 é uma crise de sobreacumulação, intrínseca e inerente ao modo de produção capitalista, que gerou uma procura do capital financeiro por novos territórios para realização de capital. A crise de acumulação deste período impulsiona investimentos em terra e a financeirização tem forte peso para isso.

A mais recente fase da financeirização surgiu como uma resposta à crise de sobreacumulação da década de 1970, momento em que os lucros dos Estados Unidos da América e dos países europeus começaram a cair, apesar da abundância de trabalhadores com baixos salários. Estes países redirecionaram seus capitais excedentes aos mercados financeiros, em atividades especulativas em que o lucro era passível de ser realizado. A financeirização surgiu como uma necessidade e uma forma de absorver o capital excedente. É nesse período que os Estados Unidos iniciam o processo de expansão do seu sistema financeiro a outros países, de maneira que a crise viria posteriormente a se propagar em efeito cascata, de uma região para a outra (HARVEY, 2011).

Os investimentos financeiros, então, buscaram refúgio em diferentes setores da economia, como o de tecnologia e o imobiliário. No período mais recente, o 
setor agrícola se tornou destino destes investimentos financeiros por diversos fatores (BORRAS, FRANCO, et al., 2015). A financeirização está relacionada a novos instrumentos financeiros, que permitem que investidores comprem tanto terras agrícolas quanto produções agrícolas em todo o mundo em busca de lucros, ao mesmo tempo que reduzem riscos que foram evidenciados neste contexto de crise. Estes investimentos financeiros se conectam ao fenômeno land grabbing, por conseguinte, tanto pelo seu papel sobre a crise de alimentos e as demais crises que convergem no período abarcado por esta pesquisa, visto que alcançam o mercado de alimentos, energia e até mesmo o meio ambiente, e assim aumentam o interesse por terras, bem como pelo seu papel sobre o próprio mercado de terras.

Ainda que o valor produtivo da terra continue sendo chave para atração de investimentos, como veremos adiante, o crescente interesse dos mercados financeiros pela compra e venda de terras agrícolas deve ser notado. A financeirização se refere, segundo Epstein (2005, p. 3), ao "crescente papel dos motivos financeiros, mercados financeiros, atores financeiros e instituições financeiras na operação das economias domésticas e internacionais”. Esta ampla definição destaca o papel crescente das finanças, sem excluir o papel que a atividade produtiva ainda possui na economia. Isto importa para pensar o fenômeno em análise, pois, conforme Fairbairn (2014), a terra é, simultaneamente, um ativo produtivo e um ativo financeiro. Apesar de sempre ter possuído qualidades financeiras, a partir da nova fase de financeirização, as terras agrícolas puderam ser incorporadas nos circuitos de capital por diversos mecanismos.

As qualidades financeiras da terra são fontes importantes de ganhos de capital que atraem os investidores, que se dão, por exemplo, pela valorização passiva ou valorização através de transformações na terra, como pela formalização de títulos legais de posse ou pela melhoria da infraestrutura de transportes, segundo Fairbairn. Estes investidores costumam ver as terras como fontes de retornos relativamente estáveis a longo prazo, formas de diversificação de seus portfolios e hedge contra a inflação. Estes investimentos são feitos em grande parte por bancos, empresas especializadas, fundos de investimentos e ainda 
outros, atraídos por diversos fatores. Porém, não só atores do setor financeiro tem tratado a terra como um ativo financeiro, mas também atores de dentro do agronegócio, que anteriormente viam na terra apenas seu valor de uso. Ao mesmo tempo que as qualidades financeiras da terra despertam interesses, seu valor produtivo também adquiriu uma importância renovada nos últimos anos devido a alguns fatores, como os relacionados às crises que serão debatidas adiante (FAIRBAIRN, 2014).

O argumento de Fairbairn é que é justamente essa dupla função que torna a terra singularmente atrativa para os investidores, pois a permite reservar o valor nela investido e até mesmo gerar riqueza pela sua apreciação (especulação que gera ganhos de capital), ao mesmo tempo que permite a produção, gerando rendimentos. As recentes apropriações de terras em larga escala combinam ambos os papéis da terra, isto é, são motivadas tanto pela produção quanto pela especulação, que podem ocorrer, e frequentemente ocorrem, ao mesmo tempo (FAIRBAIRN, 2014). A distinção entre as operações financeiras e as produtivas no tocante a terras agrícolas é, entretanto, frágil. A crise alimentar global contemporânea reflete a complexidade e a proximidade entre estas duas atividades, como expõe-se a seguir.

A crise alimentar global do período de 2007-2008 concerne os altos níveis e a extrema volatilidade dos preços agrícolas, fenômeno a que se tem chamado de "agroinflação" (CLAPP e HELLEINER, 2012). Essa crise se formou de maneira complexa, de modo que é necessário observar diversos fatores para compreendêla, ainda que não haja um entendimento cerrado sobre esta. Os efeitos da crise foram sentidos em todo o mundo e particularmente nos países em desenvolvimento, em que a flutuação frequente dos preços afetou profundamente os consumidores e restringiu o acesso a produtos alimentares. Apesar do declínio nos preços já a partir da segunda metade de 2008, os preços nesses países permaneceram altos nos anos posteriores (CLAPP e HELLEINER, 2012).

Jennifer Clapp e Helleiner (2012) indicam que, no momento inicial da crise, diversos autores a associaram a questões relativas a oferta e a demanda por 
alimentos. Dentre os motivos frequentemente citados na literatura sobre o tema estão o aumento na busca por alimentos por alguns países, que passavam por crescimentos econômicos e/ou que buscavam fontes em outros países para garantir seus abastecimentos internos, devido a preocupações com suas seguranças alimentares. Além disso, fatores como a estagnação da produção nos países mais pobres do mundo, secas e questões ambientais, dada a mudança climática, aumento nos preços dos petróleos, entre outros, são amplamente citados. Porém, para os autores, estas e outras razões que explicam a crise com base em processos de acumulação física não dão conta de explicar a severidade da volatilidade dos preços (CLAPP e HELLEINER, 2012). A financeirização se torna chave para a compreensão.

Estes autores afirmam ainda que, enquanto alguns trabalhos destacaram o papel central da especulação financeira para a crise alimentar, outros entenderam que o papel desta era mínimo. Philipp Mcmichael (2009), importante autor sobre regimes alimentares, defende o peso da financeirização neste processo. Mcmichael afirma que o aumento nos preços dos alimentos neste período se deveu ao aumento na demanda por energia e alimentos, em um contexto de pico do petróleo e a busca por culturas para combustíveis alternativas, processo sobre o qual a especulação financeira teve papel central. $O$ aumento nos preços atraiu diversos investimentos financeiros em alimentos, que se combinou a especulação financeira com o mercado futuro de commodities, dentre outros aspectos.

Com relação à crise de alimentos, a financeirização está associada ao aumento da volatilidade dos preços dos alimentos, que afeta o acesso aos alimentos por determinadas populações e aumenta os incentivos para investimentos em mercados agrícolas por atores financeiros, inclusive terras. Atores financeiros têm investido em agricultura há muito tempo, especialmente por meio de mercados de futuros. Esse mercado tem aumentando significativamente nos últimos anos e compreende diversas operações (CLAPP, 2015). Propõe-se refletir brevemente sobre um exemplo de contrato deste mercado, como forma de entender como este se relaciona à crise de alimentos. Os contratos derivativos podem ser compromissos a termo (forward commitments) ou 
de exercício contingencial (contingent claims). O primeiro tipo se destacou neste período, pois possibilita que o comprador adquira um ativo em uma data futura específica por um preço pré-determinado na contratação e garante segurança contra mudanças de preços futuras (BM\&FBOVESPA - CVM, 2015), tão comuns no período da crise de alimentos.

Este tipo de contrato, assim como outros contratos de futuro, não só garante proteção contra a volatilidade dos preços das commodities a compradores e vendedores, como também tem papel de 'descobridor de preços', visto que os atores dos mercados de commodities passam a confiar nos preços futuros destes contratos, segundo Clapp. Além disso, esses mercados atraíram diversos especuladores, que investem nos contratos de preços de alimentos a curto prazo como forma de diversificação de seus portfolios e compõem o problema da crise de alimentos. A desregulação financeira contribui para a especulação futura com commodities ao atrair investidores para a agricultura (CLAPP, 2015).

$\mathrm{O}$ aumento da participação de atores financeiros e a criação de novos instrumentos financeiros têm consequências para o sistema alimentar. Isto contribui para o que Clapp (2014) indica ser um "distanciamento" no sistema alimentar, em que "distância" se refere ao espaço que existe entre produtores e consumidores de comida. A grande financeirização no sistema alimentar global contribui para tal distanciamento pelo aumento no número de atores envolvidos nas cadeias globais de commodities agroalimentares e pela abstração da comida da sua forma física para derivativos de alta complexidade, que são incompreensíveis para a maior parte da população. Este distanciamento obscurece o papel dos atores financeiros e os custos colocados por suas atividades, tornando mais difícil a luta de grupos que buscam a redução do impacto das finanças sobre a volatilidade dos alimentos e sobre a fome.

Em suma, a crise de alimentos representa um forte impulso para o aumento nas transações de terra em todo o mundo. Apesar da dificuldade encontrada por diversos atores envolvidos em land grabbing para evidenciar o fenômeno, conforme mencionado anteriormente, a plataforma online do Land Matrix fornece 
dados que indicam, ainda que não de modo absoluto, a dimensão e o peso que os alimentos possuem sobre as aquisições de terras. Com o auxílio destes dados, pode-se notar que a agricultura representa a maior parte das intenções das aquisições de terra em todo o mundo $(24,1 \%)$ (Figura 1), seguida por silvicultura (forestry) (12\%). Entre os investimentos realizados por agricultura, em termos globais, os alimentos representam 38\% das intenções dos investimentos, seguidos por outros usos de agricultura não especificados (23\%) e agrocombustíveis (21\%) (Figura 2) (NOLTE, CHAMBERLAIN e GIGER, 2016).

Figura 4. Intenção das Aquisições de Terras (2000-2016)

\begin{tabular}{|lcc|}
\hline INTENTION & $\begin{array}{c}\text { NUMBER OF TIMES INTENTION IS } \\
\text { MENTIONED }\end{array}$ & $\begin{array}{c}\text { TOTAL CONTRACT SIZE } \\
\text { (MILLION HECTARES) }\end{array}$ \\
\hline Agriculture & 1403 & 24.1 \\
\hline - Agrofuels & 221 & 5.1 \\
- Food crops & 553 & 9.2 \\
- Livestock & 130 & 2.0 \\
- Non-food agricultural commodities & 236 & 2.3 \\
- Agriculture (unspecified) & 263 & 5.6 \\
\hline Forestry & 187 & 12.0 \\
Tourism & 25 & 1.7 \\
Industry & 33 & 0.4 \\
Conservation & 20 & 1.4 \\
Renewable energy & 57 & 0.9 \\
Other intention & 28 & 1.0 \\
No information & 30 & 1.0 \\
\hline Total & 1783 & \\
\hline
\end{tabular}

Note: Individual deals can have up to five different intentions listed. The Land Matrix does not provide information on the share of area for each intention; hence for this report we have divided the area under contract and attributed equal shares to each intention. We count the number of times an intention is mentioned and for

Source: Authors' calculation based on Land Matrix data, April 2016.

Fonte: Nolte, Chamberlain, Giger, Land Matrix Analytical Report, 2016. 
Figura 5. Intenções das Aquisições de Terras em agricultura por região (\% da área) (2000-2016)

\begin{tabular}{|c|c|c|c|c|c|c|}
\hline & AFRICA & EUROPE & AMERICAS & ASIA & OCEANIA & GLOBAL \\
\hline Agrofuels & $32 \%$ & $1 \%$ & $29 \%$ & $16 \%$ & $16 \%$ & $21 \%$ \\
\hline Food crops & $39 \%$ & $45 \%$ & $50 \%$ & 2196 & $30 \%$ & 3896 \\
\hline Livestock & 396 & $17 \%$ & $16 \%$ & $1 \%$ & $11 \%$ & $8 \%$ \\
\hline $\begin{array}{l}\text { Non-food } \\
\text { agricultural } \\
\text { commodities }\end{array}$ & $9 \%$ & $19 \%$ & 196 & $299 \%$ & 39 & $9 \%$ \\
\hline $\begin{array}{l}\text { Agriculture } \\
\text { (unspecified) }\end{array}$ & 1796 & $37 \%$ & 496 & 3396 & $40 \%$ & 2396 \\
\hline
\end{tabular}

Note: Individual deals can have up to five different intentions listed. The Land Matrix does not provide information on the share of area for each intention; hence for this report we have divided the area under contract and attributed equal shares to each intention.

Source: Authors calculation based on Land Matrix data, April 2016.

Fonte: Nolte, Chamberlain, Giger, Land Matrix Analytical Report, 2016.

Estes dados mostram como Land grabbing é um fenômeno complexo e envolve diversos aspectos, e não deve ser compreendido pelo foco em apenas um fator que influi neste processo, como fazem inúmeros trabalhos que centram suas explicações na crise alimentar por considerarem-na o principal impulso entre todos. Observa-se que perspectivas centradas apenas em alimentos podem tornar a compreensão do fenômeno estreita e conferir destaque a determinados land grabbers, como China e Índia, que possuem problemas de insegurança alimentar e, por essa abordagem, se tornam o centro de pesquisas acadêmicas, em detrimento de outros países que também fazem land grabs (BORRAS JR., KAY, et al., 2012).

A demanda por energia é também um dos maiores impulsos para as aquisições de terras no período recente, conforme a Figura 3. A crise energética, que ocorre também neste momento, se conecta a crise alimentar por alguns pontos. Neste período, houve um aumento significativo na demanda por energia e a "agroinflação" foi, em grande parte, conduzida pelo aumento nos preços dos biocombustíveis. Isso ocorre porque diversas culturas alimentares são deslocadas para a produção de combustíveis. Em consequência, a expansão na produção de biocombustíveis pode ser vista como prejudicial à produção de alimentos, visto 
que ambos competem pelo bem escasso que é a terra e pelo uso de culturas (MCMICHAEL, 2009).

Ao mesmo tempo, o medo quanto ao aumento e a volatilidade dos preços dos combustíveis ou mesmo o medo da perda de soberania nacional pela estrangeirização de recursos energéticos, abriu demanda para novas formas de extração de recursos para segurança energética e desenvolvimento nacional (WHITE, BORRAS JR., et al., 2012). A crise ambiental, por sua vez, envolve diversos elementos e está associada à crescente consciência quanto a limitação de recursos naturais no planeta, à poluição, às mudanças climáticas e ao aquecimento global decorrente do atual modelo mundial de geração de energia, entre outros.

Os biocombustíveis apareceram nos anos recentes como resposta tanto à crise energética quanto à ambiental. Dentre as razões para isto encontradas na literatura, destacam-se o aumento nos custos de produção, processamento, transporte e outros em um contexto de pico no preço do petróleo e o desejo de alguns países de reduzirem suas dependências de combustíveis de países do Oriente Médio e construírem complexos industriais de biocombustíveis para garantir suas seguranças energéticas (BORRAS JR, MCMICHAEL e SCOONES, 2010). Em especial, os biocombustíveis são apresentados como uma forma de reduzir ou transformar os padrões de uso de energia com vistas a melhorar as condições ambientais sem afetar o crescimento econômico (BORRAS JR, MCMICHAEL e SCOONES, 2010).

Mcmichael (2012) chama a atenção para este ponto ao defender que os processos que resultam em land grabbing vem acompanhados pela ideologia dos cercamentos em nome da humanidade, que precisa de alimentos e do meio ambiente, pela busca de energias alternativas. Ambos dependem do acesso à terra em todo o globo. A crise de acumulação deste período impulsiona e justifica investimentos em terra, em nome, especialmente, da escassez de alimentos e de energias alternativas. Este ponto será retomado nos próximos capítulos, ao analisar como este discurso é utilizado pelas iniciativas de regulação do fenômeno. 
Além disso, o crescimento das chamadas flex crops e flex commodities atraem os interesses dos investidores. Estas são culturas e commodities com usos múltiplos e flexíveis, como comida, alimentação de animais, combustíveis, materiais industriais e mais, cujos usos podem ser intercambiados entre tais atividades, conforme lacunas no fornecimento ou o modo mais lucrativo em diferentes circunstâncias - como mudanças nos preços ou políticas públicas mais ou menos favoráveis a determinado uso, por exemplo. Dentre os flex crops mais populares estão o milho (usado para alimentos, ração, etanol), olho de palma (usado para alimentos, biodiesel, usos comerciais/industriais), soja (usado para alimentos, ração e biodiesel) e cana-de-açúcar (usado para alimentos, etanol) (BORRAS, FRANCO, et al., 2015).

Borras, Franco, Isakson, Levidow, \& Vervest (2015) argumentam que os flex crops e as flex commodities possuem potenciais de mitigar riscos de investimentos e maximizar retornos e que, devido a isso, se tornam especialmente atraentes ao capital financeiro especulativo. Esses produtos podem ser comercializados em diferentes mercados, o que confere a eles maior liquidez para os investidores, que podem facilmente convertê-los em dinheiro. A emergência destes produtos contribuiu para a financeirização de alimentos e da agricultura e tem impacto sobre os preços destes em suas formas físicas. A complexidade destes processos exige, no entanto, exames mais detalhados, que não cabem no escopo deste trabalho.

A expansão dos agrocombustíveis em diversos países do mundo tem gerado uma crescente preocupação em relação a garantia de direitos sobre terras e direitos humanos nestes locais. Estas preocupações estão ligadas à land grabbing, pela forma com que terras têm sido adquiridas e como os ocupantes anteriores das terras são tratados ou incorporados nestes processos. Além dos combustíveis, outras respostas à crise ambiental geram preocupações: a criação de mercados de carbono e a criação de reservas verdes, por exemplo. Essas novas respostas levam ao que se vê como 'apropriação verde com fins ambientais', em que se controla não propriamente a terra, mas os recursos verdes associados a ela, como florestas 
e outros, em contexto de mudanças climáticas (WHITE, BORRAS JR., et al., 2012).

Em síntese, este capítulo buscou compreender os land grabs, definidos como apropriação de terras, e discutir em que contexto se deu a intensificação destas práticas. Os dados e análises expostos acima e, sobretudo, a teoria de David Harvey e os argumentos de Saskia Sassen contribuem para mostrar as contradições históricas que tornaram a corrida global por terras na primeira década do século XXI um fenômeno possível. Land grabbing é parte de mudanças maiores na economia global e nos mercados financeiros na análise do desenvolvimento capitalista global nesta fase, em que são intensificados por particularidades do período, como a convergência de múltiplas crises e a financeirização da terra e de commodities. 
3.

\section{Governança Global e Land Grabbing}

A terra foi mantida afastada dos debates a nível internacional e global durante décadas, e nos últimos anos foi retomada pela agenda global em grande parte devido aos land grabs. A governança a nível global da terra surge em um momento de intensificação destas práticas, em que land grabbing se torna um fenômeno global, e diversas iniciativas regulatórias que tratam do tema são criadas por organizações de diferentes naturezas. O conceito de governança global surgiu nas últimas décadas do século $\mathrm{XX}$, formando-se um campo de estudos em torno deste conceito central para a disciplina de Relações Internacionais, sobre o qual deve-se debater brevemente. Esta dissertação se apoia em conceitos da teoria crítica neogramsciana e suas ideias sobre a governança global, como forma de analisar as iniciativas de governança global de terras.

Este capítulo busca refletir sobre o que transformações do ponto de vista do capitalismo neoliberal representam para a governança global do fenômeno em consideração. Entende-se que devem ser observados os agentes propulsores dessas mudanças na ordem, assim como os interesses que os motivaram e as estratégias utilizadas para garanti-los. A governança de diversos temas, que antes eram restritos ao âmbito estatal, recebe cada vez mais participação de atores privados, com regulações que possuem mecanismos cada vez mais flexíveis para garantir conformidade. Os principais mecanismos de regulação deste fenômeno foram elaborados por atores chaves para a compreensão destas mudanças recentes, como o Banco Mundial e agências do sistema ONU. Tanto land grabbing quanto a sua governança estão diretamente relacionados a transformações na ordem mundial nas últimas décadas, em termos políticos, econômicos, sociais e outros. Em vista disso, este trabalho defende que a análise de tais mecanismos deve ser vista em perspectiva histórica e com vistas a compreender tais mudanças, o recorte histórico desta pesquisa compreende o período de 1970 até os dias de hoje. 
O capítulo foi construído, em primeiro, pela introdução ao conceito de governança global e pela reflexão sobre como este é pensado no campo teórico dominante das Relações Internacionais. Em seguida, resgata-se brevemente debates quanto à emergência da globalização neoliberal e de uma política cada vez mais global. A partir disso, a dissertação volta-se à teoria crítica neogramsciana, que fornece as bases teóricas para esta pesquisa, que tornarão possível analisar a relação entre as transformações recentes na ordem mundial e a governança do fenômeno em análise, bem como a relação de forças e as contradições inerentes à esta governança. Por fim, busca-se refletir sobre a incorporação do tema land grabbing à agenda de governança global.

Os objetivos do capítulo são, assim, três: refletir sobre o que é governança global e analisar como diferentes abordagens da disciplina de Relações Internacionais tratam o tema; refletir sobre a globalização neoliberal contemporânea, logo, a emergência do neoliberalismo, e os impactos deste sobre a governança global e até mesmo sobre diversas esferas da vida; e, a partir disso, pensar como land grabbing se tornou um tema de governança global.

\section{1. \\ O conceito de governança global e as Relações Internacionais}

O conceito de governança global se consolida nos debates políticos e na academia a partir dos trabalhos da Comissão de Governança Global na década de 1990 (ARAGÃO, 2010). A governança global surge como conceito e área de estudo em resposta aos problemas de ordem global, como HIV/AIDS, mudanças climáticas e outros, que foram entendidos como questões que não poderiam ser administradas somente por um Estado (ROSENAU, 1992). Tal conceito é importante para a disciplina de Relações Internacionais e pode ser visto a partir de diferentes perspectivas teóricas dessa disciplina, como as realistas, liberais, construtivistas e a teoria crítica com base no pensamento de Gramsci, sobre a qual este trabalho se baseia. 
James N. Rosenau é um cientista político que se destaca pelas suas obras sobre governança global. Para o Rosenau (1992), a emergência da governança global está ligada às transformações no mundo nas últimas décadas, que contribuíram para mudanças no local de autoridade para tratar de alguns temas. Os governos nacionais, ainda que possuam soberania de diversas maneiras sobre tais temas, como os mencionados acima, tiveram nesse processo parte de suas autoridades delegada a outras instâncias. Nesse sentindo, cabe observar a distinção feita pelo autor entre governo e governança. Governo diz respeito às atividades sustentadas por autoridades formais, com poder político para assegurar a implementação das políticas, enquanto governança diz respeito a "atividades apoiadas em objetivos comuns, que podem ou não derivar de responsabilidades legais e formalmente prescritas e não dependem, necessariamente, do poder de polícia para que vençam resistências e sejam incorporadas" (ROSENAU, 1992, p. $4)$.

Governança é, assim, um conceito mais amplo que o de governo, pois envolve não somente instituições governamentais, mas também outros mecanismos informais e não governamentais, e uma ampla gama de atores, como corporações multinacionais, organizações não governamentais e outros. A governança funciona, para este autor, somente se aprovado pela maioria, o que sugere que não há necessidade de um governo ou autoridade formal para ser exercitada. Disso surge sua difundida ideia de governança sem governo (ROSENAU, 1992). Para as relações internacionais, significa dizer que há governança, ordem, mesmo sem a existência de uma autoridade supranacional. As ideias de funcionamento em conformidade com o desejo da maioria e a efetividade defendida por Rosenau, entre outras ideias, são, entretanto, disputadas. A partir dos pressupostos analíticos da teoria crítica neogramsciana, defende-se o olhar crítico para governança, observando que suas iniciativas são conduzidas por atores e interesses que se relacionam de forma assimétrica, que, portanto, tornamna controversa. Retornaremos a este ponto na próxima seção.

A governança global e organizações internacionais são temas centrais da disciplina de Relações Internacionais, que historicamente se preocupa em 
compreender como o mundo é governado e como se dão as relações entre os diferentes atores envolvidos nesse processo. Diferentes perspectivas teóricas da disciplina compreendem estas questões de forma diferentes. Propõe-se refletir brevemente sobre algumas destas perspectivas, a fim de basear as discussões posteriores sobre o tema.

A perspectiva realista das Relações Internacionais, tanto em sua variante clássica como a neorrealista, dominante no período pós-guerra, contesta a possibilidade de cooperação duradoura entre os Estados e o próprio papel das instituições internacionais sobre o sistema. Os autores desta corrente entendem que a governança transnacional é sem sentido, dada a inexistência de uma autoridade supranacional e a busca constante dos Estados por sobrevivência, em um sistema de incertezas (HALE e HELD, 2011). A expansão das relações transnacionais nesse período representou desafios à teoria realista das Relações Internacionais. Nos anos de 1970, o domínio da perspectiva (neo)realista é questionado por autores que apontam para a crescente interdependência entre os países.

Os autores do internacionalismo neoliberal valorizam os momentos de interesses comuns entre os Estados, pois defendem que, nestes momentos, as relações entre estes passam a ser de cooperação. As instituições mudam o ambiente em que os Estados operam ao proverem informações e interações contínuas, que incentivavam suas relações. Dessa forma, as instituições têm poder sobre o comportamento dos Estados. Isto ocorre primordialmente por meio de sistemas de regras, normas, práticas e outros (WEISS e WILKINSON, 2014); (HALE e HELD, 2011). No período que segue, a governança global se torna mais complexa e passa a envolver não só Estados, tratados formais ou organizações interestatais, mas, também, uma mistura de política doméstica e internacional, aumento do papel de atores não estatais, emergência da governança privada, novas formas de estimulo a conformidade com os padrões e uma crescente complexidade institucional. 
Ambos (neo)realistas e institucionalistas entendem que o Estado pode ser estudado como um ator unitário, com um interesse nacional coerente. Ao longo dos anos, contudo, cresce o número de autores que defendem que este pressuposto deveria ser flexibilizado, como forma de compreender melhor o comportamento dos Estados e dos grupos que o compõem. A disciplina de Relações Internacionais vê crescer também cada vez mais o número de trabalhos que questionam o próprio pressuposto de que o Estado era um ator único e que passam a notar os atores domésticos, antes deixados à margem pelas correntes mainstream.

Este trabalho parte de determinados conceitos da teoria crítica neogramsciana, que nasce como uma crítica metodológica e epistemológica às teorias realistas e institucionalistas neoliberais. $\mathrm{O}$ conceito de Estado desenvolvido por Gramsci e retomado pelos autores que se esforçam em traduzir seu pensamento para as Relações Internacionais constitui um dos principais pontos de diferença entre as teorias. Nesta perspectiva, o Estado é formado não só pelo aparelho estatal estritamente, isto é, pelo aparelho administrativo, coercitivo e executivo (sociedade política), mas, também, pela sociedade civil. É no Estado, em seu sentido ampliado, que os conflitos sociais acontecem, logo, onde as hegemonias das classes sociais podem ser construídas (COX, 2007).

Neste contexto de deslocamento do foco analítico da disciplina para outros atores que não só o aparelho estatal, destaca-se os estudos sobre a sociedade civil e, particularmente, a atuação global de movimentos sociais de resistência. Os espaços de atuação dos movimentos sociais, como nos temas trabalho e agricultura, não se restringem ao nível local, mas ocorrem globalmente, como nota-se pela crescente articulação de redes globais de diversos atores da sociedade civil. O papel desempenhado por estes atores sobre o fenômeno em análise é fundamental e inclui a busca por evidenciar os conflitos envolvidos nas práticas de land grab, a luta pela regulação do fenômeno e a proposição de modelos alternativos de desenvolvimento rural. Parte importante da atuação destes atores ocorre junto a organizações internacionais, como a FAO. 
As organizações internacionais também passam a receber maior atenção na disciplina. Tradições de pensamento mais críticas, como as marxistas clássicas ou neogramscianas, argumentam que organizações transnacionais ou globais são respostas às exigências da expansão do capitalismo no mundo. $\mathrm{O}$ imperativo de organização, para estas perspectivas, é a facilitação da expansão capitalista (WEISS e WILKINSON, 2014). Para analisar as iniciativas de organizações internacionais para a regulação global das apropriações de terra e discutir seus efeitos sobre o land grabbing, esta dissertação parte dos pressupostos da teoria crítica de base neogramsciana, cujos principais conceitos e debates feitos serão retomados adiante neste capítulo.

A seção seguinte desta dissertação visa debater brevemente como a governança global no período contemporâneo está significativamente associada a transformações na ordem mundial, em especial, à emergência da globalização neoliberal, que levou a mudanças nos Estados e nas organizações internacionais, e conferiu maior poder a outros atores. Transformações recentes na política e economia mundial são fundamentais para compreender a governança global no mundo contemporâneo e, por conseguinte, compreender o tratamento do fenômeno land grabbing por atores desta governança.

\section{2.}

\section{Transformações recentes na política e economia mundiais}

O objetivo desta seção é refletir sobre as transformações recentes na ordem mundial contemporânea, sobretudo na economia política global. A globalização neoliberal constitui um elemento central para pensar estas transformações, que levaram a mudanças nos Estados e nas organizações internacionais, e conferiram poder a outros atores e que refletem na governança global.

O conceito de globalização não é um consenso entre os seus estudiosos e constitui um grande debate na academia, em que diversas abordagens o pensam de forma diferente. As teorias da globalização produzidas nas décadas de 1990 e 
2000 e os debates sobre o tema giram em torno de mudanças que têm acontecido nas últimas décadas, e parecem concordar que existe algo acontecendo, mas não concordam em como defini-lo ou como analisá-lo. Por vezes, o debate da globalização torna-se obscurecido pela confusão conceitual em torno do próprio termo (AMOORE, DODGSON, et al., 1997). Não cabe, todavia, no escopo deste trabalho, o resgate destes debates e estudos, dada a limitação de espaço e tempo desta pesquisa. Interessa para esta pesquisa refletir particularmente sobre alguns aspectos relacionados à globalização, sejam estes: as mudanças trazidas pela globalização para a governança global; e a relação entre Estado-nação e globalização.

O debate sobre as mudanças trazidas pela globalização para a governança global deverá ser aprofundado no desenvolvimento dos conceitos da teoria crítica neogramsciana na próxima seção. As mudanças recentes na ordem mundial envolvem o crescimento e o aumento do poder do capital, das ideias e ideologias neoliberais e a imposição de quadros constitucionais ou quase constitucionais que apoiam estes processos, como será defendido adiante pela teoria de Stephen Gill. Estas mudanças são postas em marcha por agentes, cujas ações e estratégias buscam moldar o mundo conforme seus interesses. A globalização envolve uma política de supremacia de um bloco histórico que promove as ideias neoliberais, o que se reflete na governança global, marcada pela crescente participação de atores privados. Diante disto, tem-se que a principal transformação na governança global associada à globalização é a emergência, expansão e entrelaçamento de uma perspectiva pró-mercado e neoliberal de governança, assim, uma neoliberalização da governança (SPARKE, 2013).

O processo de globalização da economia é acompanhado do processo de globalização da política. Nesses processos, a política internacional, isto é, entre Estados, começa a dar espaço para uma política cada vez mais global, que envolve a relação entre diversos atores além dos Estados, como empresas transnacionais, ONGs, redes e outros (ARAGÃO, 2010). Este debate torna necessário pontuar que este deslocamento em direção a uma política e economia mais globais, assim, 
a transferência de autoridade dos Estados para outros organismos, não significa o fim do Estado-nação, como argumentam diversos autores.

A relação entre o Estado e os processos de reestruturação global é vista de forma diferente por escolas de pensamento diferentes. Louise Amoore et al. (1997) identificam três escolas principais: em primeiro, os autores identificam uma corrente de pensamento dominante. Esta corrente considera que os movimentos transnacionais significam o desmantelamento das bases do Estadonação, visto que perderia grande parte de sua autoridade sobre a economia e sociedade pela delegação a outros organismos, assim como perderia sua soberania sobre a formulação de políticas econômicas para os mercados globais.

Uma das ideias centrais dessa corrente é que a globalização é um processo irreversível e, principalmente, inevitável, o que implica na ausência de alternativas a tal processo. Ademais, autores de tal corrente argumentam frequentemente que existe um conflito entre o mercado e o Estado: entende-se que, com o mercado globalizado, seria possível superar os entraves políticos das regulações estatais e as fronteiras nacionais, vistas como problemas à livre circulação de capital, informações, indivíduos e mais.

A formação discursiva por trás do conceito de globalização envolve as ideias de que privatizações e a transnacionalização do capital são inevitáveis ou desejáveis. Defende-se que, através do livre mercado, alcança-se progresso social ilimitado, assim como eficiência financeira, bem-estar e democracia. Aliado a esta ideia estão teorias como a de Francis Fukuyama, que veem a globalização como o "fim da história", isto é, como o triunfo do liberalismo - objetivo e destino de todos os Estados. A esquerda política, por outro lado, tem historicamente buscado mostrar como forças de mercado neoliberal marginalizam alternativas não baseadas no mercado, além de aprofundar outras contradições (GILL, 2008). Este discurso serve aos interesses daqueles que estão no comando do processo de internacionalização, que buscam enfraquecer os Estados nacionais e remover as resistências aos seus interesses econômicos e políticos. 
A segunda escola, por sua vez, vê a primeira escola como exagerada, porque os fundamentos da economia global permanecem em grande parte nacionais. Algumas estruturas e instituições do Estado interagem com a economia política internacional, e o Estado ainda é capaz de exercer grande autoridade na gestão da economia nacional. A terceira escola defende que o Estado não diminui seu significado frente a globalização. Os processos nos quais a reestruturação global ocorre estão incorporados nas estruturas e instituições do Estado, o que demonstra a sua importância para que estes processos ocorram (AMOORE, DODGSON, et al., 1997). Desse modo, tanto a segunda quanto a terceira abordagem reconhecem que o Estado é fundamental para os processos de globalização e combatem o discurso de inevitabilidade presente na primeira abordagem, ideias com as quais esta pesquisa concorda.

Está em debate, assim, a (in)capacidade dos Estados de lidarem com as forças globais que penetram seus territórios. Reconhecer que a globalização neoliberal não é um processo inevitável para o qual não há alternativa, mas sim um produto de configurações históricas, torna possível pensar em como construir resistência a estas reestruturações. Nesse sentido, este trabalho defende que os processos de globalização não levam ao fim do Estado-nação, mas que, ao contrário, este tem importância fundamental. A importância do Estado se nota, em especial, na criação das condições necessárias para a expansão do capital. A teoria do novo imperialismo desenvolvida por Harvey, e resgatada no capítulo anterior, explicam a importância que a gestão do Estado possui para a criação do capital e dos fluxos monetários, fundamentais à circulação do capital (HARVEY, 2011).

Ademais, o poder do Estado e os seus sistemas legais que codificam, definem e aplicam as obrigações contratuais para impor direitos à propriedade privada são vitais. $\mathrm{O}$ próprio direito à propriedade privada e os direitos humanos individuais pertencem a quase todas as teorias contratuais de governo. Para ser uma propriedade privada, uma coisa ou um processo, tem que ser claramente cercado/definido, nomeável e identificável (no caso da terra, deve haver mapeamento cadastral das terras e registros). Quer dizer, estes registros são indispensáveis para haver propriedade privada, que podem ser compradas e 
vendidas. Ao mesmo tempo, o monopólio sobre o uso legitimo da força e da violência do Estado são necessários para reprimir e policiar tentativas contrárias ao regime de direitos de propriedade privada, como forma de protegê-lo e preservá-lo (HARVEY, 2014, p. 42).

A própria prática da governança neoliberal tem sido possibilitada por algumas estruturas do Estado, por formas de governo que servem aos interesses do mercado transnacional e que permitem sua livre circulação. O conceito de novo constitucionalismo que será desenvolvido complementa esta argumentação. À vista disso, esta dissertação volta-se aos pressupostos da teoria crítica, afim de pensar como transformações recentes na ordem mundial se relacionam à governança global do fenômeno em análise.

\section{3}

\section{Teoria crítica neogramsciana e governança global}

As políticas públicas internacionais para investimentos em terra podem ser analisadas a partir de estudos das Relações Internacionais sobre a governança global e a sua relação com a ordem mundial. Esta seção tem o propósito de aprofundar a compreensão sobre a governança global a partir de uma chave crítica de análise, baseada nos conceitos e pressupostos da teoria crítica neogramsciana, que deverão ser debatidos. A teoria crítica das Relações Internacionais nasce como crítica metodológica e epistemológica às teorias dominantes e tem uma de suas principais vertentes baseada em obras do pensador Antonio Gramsci. Neste período, nas últimas décadas do século $\mathrm{XX}$, com o surgimento de novas correntes teóricas, para além das que haviam dominado o campo até então, a realista e a liberal, o campo teórico da disciplina das Relações Internacionais teve seus debates revigorados.

O pensamento de Gramsci influenciou diversos autores da disciplina, que se utilizaram de seu método de análise e conjunto de ideias, originalmente aplicados 
ao cenário nacional italiano, para pensar o internacional, ampliando a agenda de pesquisas da disciplina. Os autores da teoria crítica neogramsciana fornecem leituras ricas sobre globalização e governança global, e constituem as bases teóricas para as reflexões propostas nesta dissertação quanto à governança global.

Robert Cox é um dos autores mais proeminentes desta corrente, sobretudo pelos seus estudos que resgatam a teoria política gramsciana para pensar as relações internacionais. $\mathrm{O}$ conceito de hegemonia pode ser visto como a principal chave de conexão do pensamento gramsciano com esta disciplina. A noção de hegemonia desenvolvida por Gramsci envolve uma combinação entre coerção e consenso, que não deve ser entendida como uma forma de dominação, como frequentemente fazem outros autores da disciplina, mas sim pela construção de relativos consensos na sociedade, gerados pela combinação de poder e liderança de um grupo. A hegemonia em termos gramscianos é construída por meio da difusão de ideologias do grupo dominante, quer dizer, valores morais, políticos, culturais e materiais, que são transformadas em consenso.

O conceito de hegemonia mundial de Cox considera o Estado em seu sentido ampliado, isto é, sociedade civil e sociedade política. No nível mundial, a hegemonia é um projeto da classe dominante num determinado Estado dominante, que constrói globalmente um consenso sobre o seu projeto. Apesar de não ser benévola a todos, a hegemonia implica que um Estado funda uma ordem mundial que aparente ser universal e compatível com os interesses dos demais. Hegemonia é uma combinação entre poderes nos planos material, ideológico e institucional, que interagem de forma recíproca e atuam como mecanismos de estabilização e perpetuação de uma ordem, segundo o autor. A hegemonia no plano internacional não é apenas uma ordem entre Estados, mas uma ordem no interior de uma economia mundial com um modo de produção dominante, que penetra todos os países e se vincula a outros modos de produção subordinados (COX, 2007).

As organizações internacionais são para Cox um dos principais meios pelos quais a hegemonia se expressa. Conforme esse autor, entre as características da organização internacional que expressam seu papel hegemônico, estão: corporifica 
as regras que facilitam a expansão das ordens mundiais hegemônicas; é, ela própria, produto da ordem mundial hegemônica; legitima ideologicamente as normas da ordem mundial; coopta as elites dos países periféricos; e absorve ideias contra hegemônicas (COX, 2007).

Stephen Gill é outro autor importante da teoria crítica neogramsciana. Partindo da interpretação gramsciana de Cox sobre a ordem mundial e da observação de que na história mundial há períodos hegemônicos e não hegemônicos, defende que a globalização neoliberal observada nas últimas décadas não pode ser compreendida como uma política de hegemonia, mas sim como uma política de supremacia (GILL, 2008, p. 125). O conceito de hegemonia gramsciana implica haver uma coalizão ou aliança política nos âmbitos econômico, político e cultural do Estado e da sociedade civil, garantidos por uma combinação entre consenso e coerção. Nesse processo, ocorre uma fusão de interesses de classes. Na perspectiva de Gill, porém, nos anos recentes, a consolidação do neoliberalismo se dá com base na supremacia na formação de um bloco de forças não hegemônico, que exerce dominação de forma temporária sobre populações fragmentadas, isto é, diferente da coalizão gramsciana.

Segundo Gill, o processo atual de globalização compreende um bloco histórico que exerce políticas de supremacia, isto é, tem um projeto de hegemonia não consolidado. Cabe destacar que o conceito de bloco histórico desenvolvido por Gramsci diz respeito a uma unidade dialética em que diferentes forças de classe se aliam ao redor de ideias hegemônicas, o que pode ser visto como uma "congruência entre forças materiais, instituições e ideologias" (GILL, 2008, p. 60, 61). Um bloco histórico internacional pressupõe a aliança de classes que transpõe fronteiras, em um processo visto como natural e legítimo, pois se enraíza nas estruturas materiais e normativas da sociedade. Este bloco histórico é envolvido pelo discurso neoliberal de governança, que privilegia aspectos associados a esta ideologia, como a eficiência, o bem-estar e a liberdade de mercado e reflete as forças dominantes na globalização contemporânea, que se expressam, por exemplo, em organizações e instituições financeiras internacionais. 
Stephen Gill defende a existência de três estruturas históricas dominantes na ordem mundial contemporânea: o neoliberalismo disciplinar, o novo constitucionalismo e a civilização de mercado. A supremacia do bloco histórico neoliberal é organizada em âmbito global através de tais processos. Esta seção busca desenvolver estes e outros conceitos desta corrente teórica afim de compreender a governança global, para então pensar a governança global de land grabbing.

O ponto de partida de Gill é pensar a instauração do neoliberalismo no mundo, que, a partir da década de 1970, começa a ter maior força. As vidas políticas em diversas partes do mundo passaram a ser formadas por princípios políticos e econômicos neoliberais no último século, em grande parte devido ao declínio da esquerda no mundo pós-guerra e ao crescente poder do capital transnacional. As últimas décadas foram marcadas pela globalização, que pode ser vista como parte de um processo maior de reestruturação do Estado, da sociedade civil, da economia política e da cultura (GILL, 2008).

A globalização representa também uma ideologia notadamente concordante com o pensamento hegemônico mundial, que reafirma a ordem econômica global dominada pela lógica do capital (GILL, 2008). Ainda que seja um fenômeno complexo, que não pode ser reduzido a formulações simples, é central notar que globalização é um conceito que reifica o sistema econômico global dominado por grandes investidores e empresas transnacionais, que possuem grande poder sobre as produções mundiais e mercados financeiros e comércio internacional.

As mudanças recentes na ordem mundial envolvem o crescimento e o aumento do poder do capital, das ideias e ideologias neoliberais, e a imposição de quadros constitucionais ou quase constitucionais que apoiam estes processos. Esses dois processos estão ligados a dois conceitos desenvolvidos por Gill para pensar a ordem mundial contemporânea: neoliberalismo disciplinar e novo constitucionalismo, respectivamente. Ambos são fundamentais para a formação a nível global da supremacia do bloco histórico liberal transnacional (GILL, 2008) e 
busca-se a seguir refletir sobre como estes conceitos permitem compreender a governança global de land grabbing.

O conceito de 'neoliberalismo disciplinar' assinala que nas estruturas de mercado são exercitadas formas de disciplinamento. $\mathrm{O}$ disciplinamento para Gill combina as dimensões macro e micro do poder: o poder estrutural do capital; a habilidade de promoção da uniformização e da obediência entre grupos e organizações, principalmente na formação de classes associadas ao capital transnacional; e elementos particulares da prática disciplinar (controle e vigilância) no sentido de Michael Foucault, autor importante para esta formulação de Gill. Assim, o neoliberalismo disciplinar é uma forma concreta do poder estrutural e comportamental, que combina o poder estrutural do capital com a capilaridade do poder e o panoptismo (GILL, 2008, p. 137). O neoliberalismo disciplinar reconstitui o Estado, que é submetido às disciplinas de mercado, e intensifica as hierarquias sociais associadas as relações de classe, raça e gênero em escala mundial.

A expansão espacial e social do liberalismo tem sido acompanhada da disseminação da civilização de mercado, que se refere a um movimento contraditório e a um conjunto de práticas que envolvem, por um lado, ideologia, cultura e mitos, que são entendidos como uma ideologia ou mito do progresso capitalista; e, por outro lado, padrões de desintegração social e padrões de relações sociais excludentes e hierárquicos (GILL, 2008, p. 124, 125). As práticas de mercado formam parte da longue durée do capitalismo moderno e se aprofundam ao longo dos anos, ao passo que submetem diversas esferas da vida social à lógica de mercado.

A civilização de mercado que emerge com a globalização neoliberal apresenta um projeto de sociedade com visão de mundo 'ahistórica', economicista e materialista, individualista, imediatista e ecologicamente míope. A governança dessa civilização de mercado é pautada por um discurso neoliberal globalizante apoiado na interação de empresas e do Estado, coordenada pela disciplina de mercado e pelo poder político. Este processo tem por implicação o 
aprofundamento da lógica de mercado, em que relações sociais e esferas da vida são transformadas em commodities intercambiáveis, como o trabalho e a natureza (GILL, 2008). Ocorre com a globalização uma intensificação da mercantilização de elementos como a água, a biodiversidade e ainda outros recursos relacionados, como a terra, em concordância com os argumentos de David Harvey expostos no capítulo anterior, lógica presente na governança.

O neoliberalismo disciplinar é institucionalizado no nível macro do poder pelo processo que Gill denomina 'novo constitucionalismo'. O novo constitucionalismo fornece mecanismos jurídicos e institucionais que sustentam tal poder e a disciplina do capital nas relações sociais, que o conceito de neoliberalismo disciplinar implicam. Este processo pode ser observado na governança global, em que diversas organizações proveem políticas, acordos, quadros regulatórios e outros mecanismos, que pregam o que Gill chama de liberalismo transnacional como o único modelo possível de desenvolvimento. Cabe ressaltar que as leis ou quase-leis não são simplesmente superestrutura, mas sim uma forma de governo ativa, que produz autoridade política (GILL, 2014).

O novo constitucionalismo é a forma dominante de governança legal e jurídica nos dias de hoje da economia política global. Este já existia em outros períodos históricos, e pode ser entendido como parte da longue durée da formação do Estado liberal e do projeto político de blindar os ganhos de poder do capital em escala global. Porém, nos anos recentes, particularmente a partir de meados dos anos 1990, se intensificaram seus esforços para expandir e proteger a governança neoliberal e, com isso, a garantia de propriedades privadas (GILL, 2008).

Trata-se, assim, de um projeto político-jurídico baseado na primazia dos detentores de grandes propriedades privadas, com o intuito de protegê-los e tornar o neoliberalismo o único modelo de desenvolvimento a ser seguido pelos países. O novo constitucionalismo prescreve medidas de reestruturação aos Estados e à sociedade civil, que aparecem sob o formato de políticas fiscais, monetárias, de comércio e de políticas de investimento, que enfatizam eficiências de mercado, disciplina e confidência, credibilidade econômica e mais (GILL, 2008). 
Acordos de investimentos, multilaterais ou bilaterais e mecanismos ou disciplinas de pré-compromisso voltados para o futuro, possuem status quaseconstitucional à nível global. Organizações de governança tem buscado criar reformas econômicas e políticas que ganhem status constitucional e que deem suporte ao poder disciplinador do capital em escala global (GILL, 2008).

As leis ou quase-leis, em particular, o novo constitucionalismo, têm sido aliadas no processo de mercantilização da natureza, isto é, de transformação de partes da natureza em commodities intercambiáveis. Segundo Claire Cutler (2014), isto pode ocorrer, às vezes, pela constitucionalização de direitos especiais a corporações transnacionais para acesso exclusivo a coisas que eram anteriormente comuns, que representam uma nova onda de cercamentos acumulação por espoliação -, ou, outras vezes, pela abertura para o mercado de parcelas da vida que antes estavam sob o controle estatal. A importância do Estado-nação para garantir a propriedade privada deve ser também reconhecida. A imposição de direitos à propriedade privada depende da existência do poder do Estado e sistemas legais que codificam, definem e aplicam as obrigações contratuais, conforme argumenta Harvey (2014).

A mercantilização da terra por meio das leis internacionais pode ser notada também pela adoção pelos Estados de reformas agrárias neoliberais e orientadas para o mercado, vendendo terras estatais ou mercantilizando terras camponesas, e permitindo que sejam comercializadas. O papel do Banco Mundial neste processo tem grande peso. O Banco tem promovido, especialmente no Sul global, uma reforma agrária de mercado, que inclui a remoção de posse da terra de sistemas tradicionais ou não associadas ao mercado. O Banco Mundial facilita land grabs à medida em que a reforma é promovida, através da defesa de políticas amigáveis ao mercado e também pela defesa de investimentos externos, por diversos motivos, inclusive com justificativa de assegurar a segurança alimentar.

É essencial para pensar os land grabs, sublinhar que mais do que apenas blindar formas de disciplina de mercado, o novo constitucionalismo envolve três conjuntos de constrangimentos produtivos inter-relacionados que moldam a 
governança neoliberal da economia política, e que dão bases para o poder do capital. Estes elementos são medidas para: reconfigurar o Estado; criar e ampliar os mercados capitalistas liberais; conter desordem e contestações (GILL, 2014).

Quanto ao primeiro elemento, um dos objetivos centrais do novo constitucionalismo é fazer os Estados se adequarem à disciplina de mercado, sobretudo através da institucionalização ou da proteção da liberdade de movimento de entrada e saída do capital. As "boas práticas" promovidas por instituições financeiras internacionais estão associadas a este objetivo. Os Estados são estimulados a agirem como se pertencessem ao mercado e a fazerem reformas em nome de suas credibilidades e do estabelecimento de boas condições políticas para atrair investimentos. O papel do novo constitucionalismo é, dessa forma, institucionalizar proteções às empresas e investidores, em detrimento de grande parte da população. Gill argumenta que este tipo de medida limita a participação democrática das massas e até a influência parlamentar sobre aspectos centrais das economias (GILL, 2014).

O Banco Mundial aparece neste aspecto novamente como um dos principais atores do novo constitucionalismo, cujas políticas têm por objetivo a reformulação de alguns elementos dos Estados, de modo a criar ambientes mais estáveis e favoráveis à entrada de capitais externos nos países, ou seja, que ofereçam maior segurança aos investimentos e maiores lucros (GILL, 2008). A atuação do Banco Mundial no sentido de priorizar ações estatais que favoreçam a circulação de capital e ofereçam boas condições a estes está presente inclusive nas diretrizes para regulação dos investimentos em terra elaboradas sob a liderança do Banco, como será visto no próximo capítulo.

Com relação ao segundo elemento, o novo constitucionalismo possibilita institucionalizar a liberalização dos mercados de capitais, produtos e trabalho, para ampliar a acumulação de capital. Leis são reescritas nesse processo, com vistas à facilitar práticas de acumulação primitiva, como a privatização de bens públicos ou a alienação de terras e recursos comuns, em um novo processo de cercamentos. $\mathrm{O}$ direito à propriedade privada tem prioridade em relação a direitos 
trabalhistas, do meio ambiente e direitos humanos (GILL, 2014). Este aspecto do novo constitucionalismo está associado à mercantilização e financeirização de diversas esferas da vida. Este processo se relaciona com o descrito por David Harvey e seu conceito de acumulação por espoliação, visto no capítulo anterior deste trabalho, que representa uma forma importante pela qual os land grabs ocorrem.

Quanto ao terceiro ponto, Gill afirma que a administração das crises de acumulação, pelo qual o desenvolvimento capitalista tem sido ameaçado, requer a despolitização da economia. Este processo de separação entre economia e política abrange três aspectos. Em primeiro, torna legitima a retirada do caráter democrático de determinadas políticas econômicas, sobretudo através do discurso da "participação" em áreas devidamente controladas e que não interfiram na política macroeconômica (fiscal e monetária), que representa uma tentativa sistemática de cooptar e canalizar forças da sociedade civil. Isso evita contestações e retira de discussões democráticas as estratégias de política econômica e administração de crises (GILL, 2014).

Em segundo lugar, a despolitização envolve o que Gramsci chamou de transformismo. Este processo diz respeito à incorporação de tendências políticas contrárias à governança liberal ou à utilização de medidas compensatórias para prevenir a agitação de forças opositoras e ameaças à estabilidade da ordem. Isto significa que os efeitos da política de supremacia não são indisputados, mas sim contraditórios e hierárquicos e têm provocado movimentos de resistências. Assim, por meio da revolução passiva, as forças dominantes do capital transnacional buscam estabilizar sua dominância, que ocorre sem liderança.

Por último, a despolitização se conecta a tentativas de colocar questões econômicas como questões técnicas que não podem ser contestadas politicamente. Um exemplo disso foram os processos (políticos) de socialização massiva das perdas de grandes empresas nos EUA após a crise de 2008, que foram colocados como necessidades puramente técnicas, conduzidas durante uma emergência econômica, por especialistas imparciais (GILL, 2014). 
Este terceiro ponto desenvolvido por Gill é especialmente importante para o desenvolvimento do próximo capítulo. Identifica-se que as iniciativas de regulação de land grabbing agem pela despolitização do fenômeno, mas através da recuperação dos aspectos políticos deste, este trabalho busca analisá-las e refletir sobre possibilidades de mudanças. Uma crítica central de Gill a este modelo descrito é que a ordem constitucional não deveria simplesmente servir como garantia dos direitos de propriedade privada, mas sim deveria estar ligada a questões mais fundamentais de democracia. Leis democráticas deveriam envolver direitos humanos, segurança humana e desenvolvimento humano. As reformas do novo constitucionalismo têm sido impostas de cima para baixo e de fora para dentro das populações, levando a subordinação da democracia ao lucro (GILL, 2008).

Os conceitos e ideias da teoria crítica aqui resgatados possibilitam compreender que a governança global de land grabbing surge em um contexto maior de entrelaçamento entre a governança global e a globalização neoliberal. As ideias do bloco histórico neoliberal se expressam por meio de organizações internacionais e instituições internacionais e ainda outros organismos. Os processos que permitem a formação a nível global da supremacia do bloco histórico liberal transnacional, como o neoliberalismo disciplinar e o novo constitucionalismo, estão diretamente ligados à forma como tem sido construída a governança global das apropriações de terra, voltada à abertura de novos lugares para a acumulação de capital e às prioridades do capital.

\section{4 .}

\section{A terra e o land grabbing como tópicos na agenda de governança global}

O espaço internacional e transnacional existente para se pensar a terra e a complexidade de aspectos com os quais tal se relaciona, é um tema essencial para 
compreender a governança atual de land grabbing. Nota-se que a terra tem sido historicamente mantida longe dos debates internacionais e instituições de governança transnacional, e o objetivo desta seção é pensar esta relação. Identifica-se que este afastamento dos debates internacionais está relacionado a dois aspectos: a soberania dos Estados; e a conexão entre os temas agrários e lutas políticas ligadas a ideologias de esquerda.

Nas próximas seções deste trabalho propõe-se refletir, na primeira parte, sobre como a história das relações internacionais, que foi construída sobre o princípio da soberania vestefaliana dos Estados sobre os seus territórios, logo, sobre suas terras, reafirmado por diversas práticas, contribuiu para a manutenção deste afastamento da terra do âmbito internacional. Em seguida, pretende-se discutir brevemente como a ligação da terra e temas correlacionados a lutas revolucionárias mantiveram durante determinado tempo estes temas fora dos debates internacionais e como a terra foi retomada por organismos internacionais. $\mathrm{O}$ projeto de adequação da agricultura à política macroeconômica foi um forte impulso para esta retomada, porém, as iniciativas para neoliberalização da agricultura não ocorreram sem resistências. Destaca-se, nesse sentido, a ação política de organizações da sociedade civil, que passam a atuar cada vez mais para além das fronteiras nacionais e contribuem inclusive para que land grabbing seja elevado à agenda global. Por fim, o fenômeno land grabbing se torna chave para que a terra entrasse nas discussões internacionais e fossem criados mecanismos de regulação globais, marcados por mudanças recentes na governança global.

\subsection{1.}

\section{Territorialidade, terra e soberania dos Estados-nação}

A exclusão da terra e temas relacionados durante décadas das agendas globais deve-se em grande parte ao seu tratamento como um assunto restrito à política nacional/local, isto é, como pertencente às soberanias e às autoridades dos 
Estados-nação. O sistema internacional de Estados tem sido afirmado pelo ideal discursivo da Vestefália, que considera que a maior parte da autoridade política, social e econômica cabe àqueles que controlam as unidades territoriais. Trata-se de um discurso de soberania baseado em fundamentos político-territoriais, que afirma que o Estado tem o poder de controlar e definir seu espaço doméstico, que então se tornou a norma aceita e está frequentemente presente na literatura das Relações Internacionais. Este princípio é reafirmado por diversas práticas, como o reconhecimento legal de fronteiras estatais e a autoridade dos Estados de governarem livremente seus territórios demarcados (MARGULIS, 2014).

As dinâmicas do fenômeno land grabbing colocam em questão a soberania formal dos Estados. Este fenômeno representa um local de novas lutas políticas transnacionais por autoridade e controle sobre recursos e governança. Instituições e outros atores têm competido pelo controle da terra e, como Margulis et al. (2013) defendem, mais do que isso, sobre o que deve ser cultivado sobre ela, como deve ser feito, por quem, para que mercados e o que significa o futuro da agricultura global. Existem elementos e relações complexos envolvidos na delegação de autoridade a esses atores.

Cabe sublinhar que o tratamento da terra como um problema global parece trazer desafios, em certa medida, às soberanias territoriais dos Estados e à sua autoridade sobre determinados aspectos. A própria governança global implica a delegação de parte da autoridade dos Estados a outros atores, que passam a participar da administração dos temas das agendas, e, assim, atores como corporações transnacionais, ONGs ou organizações internacionais passam a ter mais poder sobre tais.

Estes aspectos remetem ao debate feito nas seções anteriores quanto ao papel do Estado e a sua incapacidade de lidar com a penetração de forças globalizantes em seus territórios. O fenômeno land grabbing está intimamente ligado à globalização no período contemporâneo e aspectos desta, como fluxos de capitais oriundos de diferentes países e capitais cada vez mais financeirizados, que adentram territórios entendidos como soberanos. 
Margulis et al. (2013) mostram que, na prática, os Estados sempre retêm alguma autoridade, pois muitas formas privadas de governança exigem consentimento explícito do Estado ou mesmo aprovação legal. Os Estados têm agido de formas diferentes frente aos investimentos de capitais estrangeiros sobre terras, de acordo com as formações dos governos e suas predisposições políticas. Enquanto determinados Estados tendem a facilitar tais investimentos, outros têm buscado medidas, particularmente de cunho legal, para freá-los (BORRAS, FRANCO e WANG, 2013). Determinados Estados têm mobilizado o discurso da soberania em busca de frear os investimentos estrangeiros em terra que têm recebido. Este é o caso do Brasil. Alguns autores mostram, entretanto, que a mobilização do discurso da soberania do Estado não tem sido assim capaz de frear o processo de apropriação de terras por capitais transnacionais (FAIRBAIRN, 2014); (SAUER e LEITE, 2012).

\subsection{2.}

\section{A neoliberalização da agricultura e a emergência de movimentos de resistência}

A terra foi mantida afastada dos debates internacionais nas últimas décadas em grande parte devido à forte associação entre os temas terra e reforma agrárias a lutas políticas e ideológicas consideradas revolucionárias, no mundo pós-guerra, dominado pelos Estados Unidos (PEREIRA, 2006). Em 1979, chegou a ser realizada a Conferência Mundial em Reforma Agrária e Desenvolvimento Rural (WCARRD, sigla em inglês) com intuito de refletir, no âmbito internacional, sobre reforma agrária e desenvolvimento rural. Nesta conferência organizada pela FAO, notou-se o desejo em se estabelecer uma governança internacional formal da terra. Porém, neste período, este tema havia perdido força internacionalmente dado o ajuste estrutural em curso e um desencantamento com a agricultura como forma de desenvolvimento (MCKEON, 2013). 
Nos anos 1990, o Banco Mundial trouxe o tema da reforma agrária de volta aos debates internacionais por meio da retomada da agenda agrária do BIRD, com vistas a adequá-la à agenda macroeconômica e política que estava sendo implementada (PEREIRA, 2006). A ação do BIRD se dava principalmente, por um lado, por meio do estimulo à mercantilização do acesso à terra rural, alcançado por mudanças institucionais e legais, e, por outro lado, por meio da defesa de programas sociais no mundo rural, para alívio da pobreza. O BIRD, nesse processo, assumiu a posição protagonista na elaboração e implementação de um agente de políticas agrárias neste período. Dentre diversas iniciativas presentes na sua agenda, destacam-se duas grandes: um arranjo institucional de administração de terras e a implementação de um modelo de acesso à terra alternativo à reforma agrária, o modelo de reforma agrária de mercado (PEREIRA, 2006).

Como pano de fundo do processo que trouxe a terra para os debates globais novamente, nota-se o envolvimento do capital. A terra se torna um elemento importante na agenda do capital, e se tornaria nos anos seguintes forte alvo de investimentos com propósitos produtivos e/ou financeiros. As últimas décadas do século XX presenciaram a expansão do neoliberalismo por diversas partes do mundo e, neste contexto de globalização neoliberal, pode-se observar a emergência do neoliberalismo também na agricultura. A agricultura, em particular nos países da América Latina, foi um dos setores mais afetados pelas reformas neoliberais colocadas em marcha nas décadas de 1980-1990, e em diversos países foram lançados programas de liberalização da agricultura, com a introdução de novas tecnologias no campo, liberalização internacional das produções agrícolas nacionais e aumento da dominação do capital no campo ${ }^{7}$. Trata-se, entretanto, de um processo amplo e complexo que não cabe no escopo deste trabalho, ao qual interessa particularmente para esta discussão destacar que o processo de globalização neoliberal não ocorreu sem a formação de resistências, que afetam a governança global da terra.

\footnotetext{
${ }^{7}$ Ver (MCMICHAEL, 2000)
} 
A década de 1990 viu surgirem diversas iniciativas alternativas ao paradigma neoliberal com a emergência de novas forças sociais, que ampliaram seus espaços de atuação para além daqueles em que se originaram. Alguns movimentos sociais rurais já haviam começado a se organizar na década de 1980 em resposta aos impactos negativos do ajuste estrutural na produção agrícola e nos modos de vida da população rural. Diversos movimentos sociais, como a Via Campesina, posicionaram-se contrários aos modelos de desenvolvimento defendido pelo neoliberalismo para a agricultura. Estes movimentos revelam que a expansão do capitalismo no contexto da globalização neoliberal não foi consensual, mas marcado por conflitos.

Os momentos e processos históricos mencionados ao longo deste capítulo apontam para a ligação entre processos que ocorrem a níveis locais e globais, que se relacionam de forma complexa. Apesar de originadas no âmbito local, é importante reconhecer que as organizações da sociedade civil não têm seus espaços de ação política restritos ao nacional. A sociedade civil tem se articulado cada vez mais em redes globais e influenciado processos da política internacional. Para as populações rurais, a defesa dos seus acessos a terra representa uma das maiores motivações para se organizar e mobilizar local, nacional e globalmente (MCKEON, 2013).

Os movimentos sociais de causas diversas, como o Movimento dos Trabalhadores Rurais sem Terra (MST), ligado às lutas por acesso à terra no Brasil, e a Via Campesina, ligada a causas do mundo rural, têm desempenhado papel importante na política internacional de crítica ao neoliberalismo e na construção de propostas alternativas de desenvolvimento, em particular para o mundo rural. Cumpre ressaltar o potencial crítico e transformador que os movimentos da sociedade civil possuem. Seguindo os pressupostos da teoria crítica, entende-se que a sociedade civil, como parte do Estado ampliado, constitui não só o lugar em que as hegemonias são construídas, mas representam também atores com capacidade de transformação da ordem vigente. 
Dentre a pluralidade de movimentos sociais ligados ao campo, que possuem lutas diversas, deve-se salientar que parte desses movimentos é fundamental para compreender o tratamento do fenômeno pelas organizações internacionais que têm formulado iniciativas de regulação para os investimentos em larga escala em terra. A atuação de movimentos da sociedade civil sobre o fenômeno land grabbing é observada já nas primeiras denúncias sobre tais práticas, que chamaram a atenção de mídias, acadêmicos e ativistas, feitas por canais de comunicação e pronunciamentos de organizações da sociedade civil. Desse modo, a própria ação inicial de evidenciar o conflito por trás de tais investimentos transnacionais foi essencial para que o tema fosse elevado à governança global.

Mais que isso, determinados movimentos da sociedade civil têm atuado fortemente nos debates e negociações para o estabelecimento de instrumentos de governança global para os land grabs junto à organizações internacionais, como a FAO, por meio de mecanismos de participação. A atuação junto a esses organismos possibilita explicitar conflitos ligados ao modelo de desenvolvimento dominante e tem o intuito de fazer com o que o debate abranja as perspectivas e visões de mundo daqueles afetados pelos investimentos, isto é, por uma perspectiva que venha de baixo. O modelo de desenvolvimento dominante privilegia os interesses do capital, prioriza produções de larga-escala, industriais, monoculturas e a base de combustíveis fósseis, que expulsa pessoas de suas terras e degrada o meio ambiente (BORRAS, FRANCO e WANG, 2013).

Movimentos sociais como a Via Campesina desempenham o papel de propor um modelo de desenvolvimento alternativo, formulado a partir de concepções de mundo dos camponeses, que valorizam a terra, por exemplo, não somente pelo seu valor de mercado. Para as lógicas camponesas, segundo Mcmichael (2012), a terra significa possibilidade de subsistência e de ter seus modos de vidas preservados, e é repleta de valor espiritual, cultural e o associado às suas famílias e às histórias que possuem. Enquanto isso, para o neoliberalismo, a produção agrícola possui apenas valor econômico, separado dos outros significados. Estes movimentos defendem modos de vidas e conhecimentos locais, e, apesar de apresentarem propostas diferentes entre si, colocam em 
questão os movimentos de universalização das ideias neoliberais e dinâmicas globais do capital. A formulação de conceitos, como o de soberania alimentar ${ }^{8}$ da Via Campesina, representa alternativas vindas da sociedade civil que podem levar à transformação da ordem vigente.

Apesar da terra não estar presente nas leis internacionais, os movimentos sociais têm utilizado como estratégia em suas articulações a relação entre terra, água e alimentos, elementos que, sim, estão no direito internacional. $\mathrm{O}$ acesso à terra é fundamental para o acesso a tais. Por conseguinte, diversos movimentos sociais têm buscado se contrapor à commodificação da água através dos direitos humanos, reclamando o direito humano de acesso à água (CUTLER, 2014). Os movimentos contrários à apropriação privada e a compra e venda de terra como uma mercadoria, por sua vez, têm buscado se articular em torno da ideia de acesso à alimentos.

Nos anos de 1990, atores da sociedade civil com propostas alternativas a tal modelo começaram a participar da governança global pela primeira vez. A criação da rede global de camponeses Via Campesina, em 1993, foi, em grande parte, motivada pela ideia de que era necessário que a sociedade civil se organizasse a nível internacional, para poder defender políticas agrárias distributivas orientadas para a justiça social nesse nível (MCKEON, 2013). Um momento chave que possibilitou maior espaço para participação destes movimentos a nível internacional e para discussão do tema terra a esse nível, foi a Conferência Internacional em Reforma Agrária e Desenvolvimento Rural (ICARRD, sigla em inglês), proposta pelo governo brasileiro e promovida em parceira com a FAO, em 2006. Essa conferência trouxe o assunto da reforma agrária de volta à agenda de ações normativas FAO, além de ter conferido ganhos à sociedade civil pelo

${ }^{8} \mathrm{O}$ conceito de soberania alimentar se fortaleceu por meio das críticas da Via Campesina ao discurso neoliberal e à prática da "segurança alimentar", que correspondia a um sistema de comercialização de alimentos institucionalizado nas regras da Organização Mundial para o Comércio (OMC), e administrado por corporações transnacionais. Esse sistema teve o impacto de aumentar a dependência alimentar do Sul global no comércio internacional. A soberania alimentar emergiu como um movimento contrário a este regime alimentar neoliberal (MCMICHAEL, 2015). 
reconhecimento de diversos aspectos essenciais às suas lutas. Por exemplo, o reconhecimento do direito coletivo à terra; de que terra é fator cultural, social, histórico e econômico; referência a controle da terra e não somente acesso à terra; menção explícita ao direito a alimentos e soberania alimentar (MCKEON, 2013).

A participação constitui um debate amplo nos estudos sobre a prática de desenvolvimento, em que se ressalta, em geral, que a participação possui dinâmicas profundas, que podem ser usadas tanto para a inclusão quanto para a despolitização em determinados processos. A teoria crítica desenvolvida por Gill defende que o discurso da "participação" tem sido utilizado como uma forma de despolitizar a economia, ao evitar contestações e retirar de discussões democráticas as estratégias de política econômica e administração de crises - a participação é permitida em áreas devidamente controladas e que não interfiram na política macroeconômica. Este parece ser o caso de determinadas iniciativas de regulação de land grabbing, como pretende-se analisar no próximo capítulo.

Apesar disso, a participação da sociedade civil na formulação de mecanismos de regulação tem sido defendida como forma de conferir legitimidade para os mecanismos. A ação política, em especial da sociedade civil organizada, é impactada pelas estratégias e argumentos utilizados pelas organizações que os formulam. As diretrizes para regulação dos investimentos em terra e da posse da terra, que envolvem land grabs, em geral, destacam a importância da participação destes atores e indivíduos na formulação dos documentos, na discussão de políticas públicas, mesmo no âmbito transnacional. No âmbito da governança da terra, a sociedade civil participou da formulação do Voluntary Guidelines, elaborado pela FAO. O PRAI, elaborado por um conjunto de instituições, apesar de afirmar em seu documento a importância da participação da sociedade civil e de consultas públicas, foi amplamente criticado pela falta de consultas de qualquer tipo durante a sua elaboração, e por legitimar a tomada de terras agrícolas da população rural por corporações tanto nacionais quanto internacionais, segundo McKeon (2013). 
Para a autora Mckeon, a participação da sociedade civil durante as sessões de debate e negociação para a elaboração do VG foi crucial, de um lado, para que os seus princípios fossem negociados no âmbito do Comitê de Segurança Alimentar Mundial (CFS, sigla em inglês), e, de outro lado, para que o PRAI fosse rejeitado. O novo formato do CFS, em que decisões políticas são tomadas em sessões abertas, das quais a sociedade civil e movimentos sociais podem participar, contribuiu para que o VG fosse negociado de forma mais satisfatória, com participação (MCKEON, 2013). Como será visto no capítulo seguinte, a participação da sociedade civil é fundamental para que as vozes de baixo sejam ouvidas, todavia é essencial atentar que o debate sobre participação suscita diversas questões, visto que participação não implica sempre em resultados positivos. Estas questões estão relacionadas sobretudo à forma como o processo de participação ocorre e como estas ideias são incorporadas à elaboração e implementação de políticas.

\subsection{3.}

\section{A entrada da terra na agenda global}

Contudo, é a recente onda de investimentos em terra que constitui a razão primordial para a sua inclusão na agenda de governança global, segundo Matias Margulis (2014). As potenciais consequências de casos de land grabbing desencadearam preocupações de diversos atores, que reforçaram a demanda pela governança deste fenômeno. As demandas originadas na sociedade civil estão relacionadas ao medo quanto a deslocamentos e outras inseguranças quanto à posse de terras. A expressão mais representativa da reação da sociedade civil foi a campanha global "Stop the Land Grab", iniciada em 2011 pelo movimento transnacional de camponeses La Via Campesina, conforme mencionado anteriormente. Preocupações quanto às consequências ambientais deste fenômeno, que se combinam frequentemente ao receio quanto aos riscos sociais deste, também suscitaram reações de diversos atores (MARGULIS, 2014). 
Em decorrência destas reações, a terra começou a ganhar mais destaque no âmbito transnacional e foi incluída na agenda de governança global de diversas organizações, como o Banco Mundial e o Comitê de Segurança Alimentar Mundial. Neste período, a FAO já estava trabalhando na proposta de formulação do VG, que não foi uma resposta ao fenômeno land grabbing, ao contrário do PRAI, lançado em 2010.

Os investimentos em larga escala em terra e outros temas relacionados passaram, assim, a ser regulados por diretrizes voluntárias elaboradas por diversas organizações internacionais. Percebe-se que a governança global do fenômeno é expressão de mudanças ocorridas nos últimos anos na governança global, que contribuíram para o crescimento da sua complexidade, dada a proliferação de atores e instituições que dela participam. Esta complexidade da política mundial está associada às inovações na governança transnacional, em que Estados têm criado mais organizações intergovernamentais e tratados, ao mesmo tempo que têm, assim como outros atores, criado novas formas de instituições com autoridade para formular políticas. Neste processo, instituições internacionais e suas regras têm se expandido e se justaposto, e nota-se complexos regimes internacionais, que podem ser compostos tanto por objetivos e entendimentos harmoniosos ou diferentes (HALE e HELD, 2011).

A governança global relacionada a land grabbing é marcada por tal complexidade. Além das mudanças recentes no campo, que o tornaram mais complexo, a própria terra é um fator que se relaciona com diversos outros tópicos da agenda de governança global, como mudanças climáticas, meio ambiente, alimentos, posse de terra, direitos à terra de índios e camponeses, investimentos e outros. A pluralidade de instituições e práticas que envolvem a terra revelam a complexidade da sua governança transnacional, que toca diferentes escalas e áreas.

Por isso, é necessário ressaltar que não é possível resumir a governança deste fenômeno aos mecanismos formulados pelo Banco Mundial ou pela FAO. Diversos outros mecanismos de regulação ligados a tais áreas podem oferecer 
insumos para se pensar os investimentos em terra, visto que tocam em determinados aspectos destas práticas. Porém, esta dissertação concentra suas análises em tais iniciativas por considerá-las as mais relevantes e mais diretamente relacionadas ao fenômeno, como será desenvolvido no próximo capítulo.

Além disso, este trabalho defende que a governança de land grabbing pode ser observada a partir de mudanças que estão diretamente relacionadas à emergência de uma política neoliberal. Duas transformações recentes são importantes para pensar este fenômeno: mudanças nos atores envolvidos na governança global e nos mecanismos de governança utilizados. O primeiro aspecto diz respeito à emergência de muitas formas de governança transnacionais não centradas na autoridade pública nesse período. Atores não estatais, como indivíduos, empresas, organizações não governamentais e outras, se tornam ativos na governança transnacional. As mudanças conferiram maior papel para as corporações transnacionais e maior representação aos interesses do capital.

A governança global conferiu maior poder a atores privados, como empresas transnacionais, ao permitir que estes próprios criassem mecanismos de regulações globais, muitas vezes para gerir suas próprias ações. Este é o caso de regulações de investimentos internacionais que têm sido criadas de empresas para empresas, com mecanismos de conformidade não vinculantes. Regulações sobre os Direitos Humanos são representativos do poder das corporações transnacionais. Como mostra Aragão (2010), empresas têm elaborado mecanismos para regular suas próprias ações, em um processo que gera uma percepção de que eles seriam os mais eficientes para garantir melhores soluções de governança.

O segundo aspecto refere-se à utilização de diversos mecanismos novos para suscitar conformidade com as regras transnacionais, e, também, para monitorar a conformidade com tais regras. As formas de se suscitar conformidade até o momento eram leis formais internacionais, garantidas por algum tipo de sanção aos que as violassem. Nesse novo período, as regras transnacionais não assumem sempre a forma de lei formal e o cumprimento destas não ocorre 
necessariamente por sanções, mas há novos formatos e mecanismos de monitoramento de conformidade (HALE e HELD, 2011).

Redes transnacionais, órgãos de arbitragem, mecanismos financeiros e regulações voluntárias têm desempenhado papel cada vez maior na governança. Estas novas formas de regulação têm sido criadas por atores privados e recebem diferentes graus de reconhecimento por outros atores, como "melhores práticas", a utilização de formas de "nomear e envergonhar" ou recomendações de natureza voluntária. As regulações voluntárias interessam particularmente para pensar o fenômeno em análise, pois representam a forma pelo qual este tem sido regulado. Estas se referem sobretudo a códigos de conduta para corporações, informais, elaborados por organizações não governamentais, Estados, organizações internacionais e até mesmo por empresas.

Estas mudanças fazem a regulação passar de "comandar e controlar" para abordagens "gerenciais", que focam em aumentar a habilidade e a disponibilidade dos atores em agir em conformidade com tais regras, segundo Hale \& Held (2011). A título de exemplo, em alguns casos a transparência tem sido usada como forma de regulação - o discurso de transparência por si só faria os atores disponibilizarem informações sobre suas ações, sem a necessidade de especificar regulações ou punições (HALE e HELD, 2011).

Quanto a isso, por um lado, alguns autores argumentam que estas iniciativas podem ser incorporadas aos âmbitos sobre os quais regulam, de maneira a assumir o caráter de obrigação, ainda que tenha natureza voluntária, ou ser adotada pelo direito internacional como lei no futuro. Por outro lado, autores mais críticos argumentam que estas regulações voluntárias podem também enfraquecer a possibilidade de criação de regulações e leis futuras para temas importantes.

A crise financeira de 2008 representou uma oportunidade para ONGs e movimentos sociais demandarem mecanismos de regulação mais rígidos e que gerassem obrigatoriedades para o capital. O aumento da demanda por uma governança global menos flexível está ligado a uma descrença quanto à autorregularão do capital, evidenciada por esta crise global (ARAGÃO, 2010). 
Em contrapartida, a defesa dos mecanismos de regulação mais flexíveis, como os citados, se articula em torno da ideia de que alternativas para estas formas de regulação são difíceis ou impossíveis de serem implementadas. Diante disto, defendem que tais mecanismos são os melhores possíveis. Para os que defendem estas regulações, as mesmas não devem ser analisadas em comparação a um ideal hipotético, mas sim com outras alternativas possíveis para governança - se não há possibilidade de criação nos anos seguintes de grandes e fortes acordos sobre determinado assunto, então as regulações voluntárias parecem efetivas ao menos em parte (Hale \& Held, 2011).

Para este trabalho, estes argumentos agem de modo a enfraquecer resistências e afastar a possibilidade de criação de normas vinculantes e obrigatórias para os investimentos que possuem grande efeitos potenciais e reais negativos sobre diversos elementos. A partir dos pressupostos da teoria crítica anteriormente desenvolvidos, pretende-se, no capítulo seguinte deste trabalho, se debruçar sobre os mecanismos mais importantes para pensarmos a governança de land grabbing e refletir como ocorrem estes processos. 
4.

\section{As iniciativas multilaterais para a governança de land grabbing}

Nos últimos anos, iniciativas de governança em nível global da terra têm sido criadas, motivadas significativamente pelos casos de land grabs e preocupações quanto às suas consequências, potenciais e reais, conforme argumentou-se nos capítulos anteriores. Land grabbing é um fenômeno que contribuiu, como visto, para trazer o tema da terra de volta aos debates internacionais. As organizações internacionais que têm tratado do tema possuem diferentes naturezas, sendo algumas de âmbito econômico, como o G8 e o Banco Mundial, mas, também, organizações ligadas à agenda de desenvolvimento, como as Organizações das Nações Unidas e suas organizações satélites: agências, fundos e comitês, em especial as ligadas a alimentos e agricultura.

O presente capítulo tem por finalidade, a partir dos debates feitos nos capítulos anteriores, analisar como este tema tem sido tratado na agenda de governança destas organizações, em particular pelo Banco Mundial e pela FAO. Apesar de possuírem naturezas diferentes, identifica-se aspectos em comum entre estas iniciativas, como será argumentado ao longo do texto. Particularmente, estas tendem a incentivar os investimentos em larga escala em terra, que são representados nas narrativas destas organizações como oportunidades para o desenvolvimento das regiões em que ocorrem, desde que se minimize os riscos envolvidos na prática de land grab. A partir destas análises, pretende-se responder a pergunta de partida desta dissertação.

O capítulo busca, em um primeiro momento, pensar as iniciativas de governança da terra e itens relacionados em um contexto mais amplo de criação de diversas outras iniciativas voluntárias para regulação de investimentos "responsáveis", com vistas a oferecer um panorama sobre as iniciativas. Em seguida, esta dissertação concentra suas análises sobre duas iniciativas que se 
destacam sobre o fenômeno land grabbing, elaboradas pela FAO e pelo Banco Mundial em parceria com agências da ONU. Posteriormente, busca-se refletir sobre as possibilidades e limitações destas iniciativas quanto às suas implementações. Por fim, argumenta-se que estas iniciativas possuem consequências expressivas para o debate e ação política sobre o fenômeno.

Nesse sentido, os objetivos do capítulo são: em primeiro, analisar como determinadas iniciativas de regulação tratam o fenômeno; em segundo, refletir sobre as contradições destes posicionamentos e as suas consequências para o debate e ação política; por fim, cumprir o objetivo principal desta dissertação, seja este, analisar as iniciativas de organizações internacionais para a regulação global das apropriações de terra e discutir seus efeitos sobre o fenômeno land grabbing.

\section{1.}

\section{As iniciativas de governança dos investimentos em terra e itens relacionados}

Conforme visto no capítulo anterior, a governança global de land grabbing é expressão de mudanças ocorridas nos últimos anos na governança global, que contribuíram para o crescimento da sua complexidade, dada a proliferação de atores e instituições que participam desta. Destacou-se que, além das mudanças recentes no campo, que o tornaram mais complexo, a própria terra é um fator que se relaciona com diversos outros tópicos da agenda global. Os instrumentos de regulação dos investimentos em terra e recursos relacionados foram criados em um contexto mais amplo de criação de diversas outras iniciativas voluntárias para regulação de investimentos "responsáveis" em geral, promovidos tanto por governos quanto pelas próprias corporações transnacionais (CLAPP, 2016).

Apesar da complexidade e, por conseguinte, da pluralidade de diretrizes de governança que tocam por diferentes ângulos os investimentos em terra, identifica-se que há determinadas iniciativas de regulação que se relacionam mais diretamente ao fenômeno e que foram até mesmo elaboradas em reação ao 
fenômeno land grabbing. Dessa forma, este trabalho foca em duas principais iniciativas globais de regulação de land grabbing, elaboradas pelo Banco Mundial e a Organização das Nações Unidas para Agricultura e Alimentação (FAO, sigla em inglês), através de organizações ligadas a esta, aos quais este trabalho se dedicará nas próximas seções. Ambas as iniciativas são brevemente comparadas na tabela 1 .

Em primeiro, propõe-se analisar a iniciativa liderada pelo Banco Mundial, lançada em 2010 em parceria com a Organização das Nações Unidas para Agricultura e Alimentação (FAO), com a Conferência das Nações Unidas sobre Comércio e Desenvolvimento (UNCTAD, sigla em inglês) e com o Fundo Internacional de Desenvolvimento Agrícola (IFAD, sigla em inglês). Esta iniciativa chama-se Principles for Responsible Agricultural Investment that Respects, Livelihoods, and Resources (PRAI) e tem por objetivo propor diretrizes e melhores práticas para guiar investimentos em agricultura de forma responsável. Em seguida, pretende-se analisar o documento Voluntary Guidelines on the Responsible Governance of Tenure of Land, Fisheries and Forests in the Context of National Food Security (VG), elaborado pela FAO em 2012 com o objetivo de servir de referência e fornecer orientações para melhorar a governança de posse de terras, pescas e florestas. 
Tabela 1 - Principais iniciativas globais de regulação de investimentos em agricultura

\begin{tabular}{|c|c|c|}
\hline $\begin{array}{l}\text { Iniciativa de } \\
\text { regulação }\end{array}$ & $\begin{array}{l}\text { Principles for Responsible } \\
\text { Agricultural Investment that } \\
\text { Respects, Livelihoods, and } \\
\text { Resources (PRAI) }\end{array}$ & $\begin{array}{l}\text { Voluntary Guidelines on the } \\
\text { Responsible Governance of Tenure of } \\
\text { Land, Fisheries and Forests in the } \\
\text { Context of National Food Security (VG) }\end{array}$ \\
\hline Organizadores & $\begin{array}{c}\text { Banco Mundial, FAO, IFAD, } \\
\text { UNCTAD }\end{array}$ & $\begin{array}{l}\text { Comitê de Segurança Alimentar } \\
\text { Mundial da ONU/FAO }\end{array}$ \\
\hline Atores alvos & $\begin{array}{c}\text { Todos os investidores - públicos } \\
\text { ou privados }\end{array}$ & Estados e investidores privados \\
\hline $\begin{array}{l}\text { Natureza do } \\
\text { documento }\end{array}$ & $\begin{array}{l}\text { Documento de } 22 \text { páginas com } 7 \\
\text { princípios; voluntário. }\end{array}$ & $\begin{array}{l}\text { Documento de } 48 \text { páginas detalhadas; } \\
\text { voluntário. }\end{array}$ \\
\hline $\begin{array}{l}\text { Ano de } \\
\text { elaboração }\end{array}$ & 2010 & 2012 \\
\hline $\begin{array}{l}\text { Principais } \\
\text { temas }\end{array}$ & $\begin{array}{l}\text { Investimentos em agricultura, } \\
\text { respeito aos direitos sobre terra e } \\
\text { recursos, segurança alimentar, } \\
\text { boa governança, participação, } \\
\text { investimentos responsáveis (boas } \\
\text { práticas), sustentabilidade social } \\
\text { e ambiental. }\end{array}$ & $\begin{array}{l}\text { Governança da posse da terra, } \\
\text { recursos pesqueiros e floresta, } \\
\text { proteção dos vulneráveis e } \\
\text { marginalizados, como pequenos } \\
\text { agricultores, segurança alimentar, } \\
\text { desenvolvimento sustentável social e } \\
\text { economicamente. }\end{array}$ \\
\hline
\end{tabular}

Fonte: elaboração própria.

A iniciativa liderada pelo Banco Mundial é constituída por princípios que podem ser vistos como desdobramentos de estudos anteriores das instituições 
envolvidas na sua formulação, e foi elaborada em reação ao aumento dos investimentos em larga escala em terra no final da década de 2000, tendo como foco, portanto, os investimentos em elementos relacionados à agricultura. $\mathrm{O}$ documento elaborado no âmbito exclusivo da ONU não foi uma reação direta aos casos de land grabbing, e possui como prioridade diretrizes voltadas à pensar a posse da terra. Contudo, há um amplo reconhecimento quanto à sua importância para a governança da terra em geral, que passa pela regulação dos investimentos em terra, sobretudo por ter sido o primeiro a ser aprovado por todos os países signatários da ONU. Todos envolvem diferentes princípios, normas e discursos sobre como lidar com o fenômeno em análise, e, por isso, merecem atenção individual.

O foco em tais iniciativas é justificado pelo reconhecimento da importância de tais na então incipiente literatura sobre o tema e pela centralidade dos atores que os formularam para tratar de temas diversos, especialmente os relacionados à agricultura, no âmbito global. Apesar do foco em apenas duas iniciativas, cumpre ressaltar que é possível identificar outros diversos mecanismos que visam à regulação de investimentos transnacionais. A governança global associada a land grabbing, como visto, se relaciona a diversos outros tópicos da agenda de governança global, focados em aspectos como mudanças climáticas, meio ambiente, alimentos e outros, em um contexto mais amplo de crescente complexidade da governança global, em que regulações transnacionais tendem cada vez mais a interagir e se sobrepor. Por isso, torna-se difícil precisar as iniciativas que existem. Porém, identificam-se algumas que são voltadas diretamente ao investimento em agricultura, que devem ser destacadas. Tais iniciativas expressam certas mudanças recentes no campo da governança global frisadas no capítulo anterior, sendo todas regulações de caráter voluntário. Grande parte destas foi elaborada por investidores privados para regular investimentos privados, isto é, diretrizes elaboradas pelos próprios a quem se direcionam.

Destaca-se, assim: 1. O Principles for Responsible Investment in Agriculture and Food Systems (PRIAFS) é um dos documentos mais importantes para o tema e foi elaborado em 2014 pelo CFS, tomando-se como base o PRAI, que não foi 
endossado no âmbito deste comitê, afim de criar um novo documento com diretrizes elaboradas a partir de consultas à sociedade, conferindo maior legitimidade para as propostas, comparativamente; 2. O Principles for Responsible Investment in Farmland (PRI) é uma rede de investidores que elaboraram conjuntamente princípios voluntários, em 2011, que possuem por objetivo guiar a ação de grandes investidores institucionais, como os fundos de pensão, incluindo o TIAA-CREF'; 3. O The Responsible Investor's Guide to Commodities, por sua vez, foi lançado em $2011 \mathrm{em}$ uma iniciativa conjunta do Global Compact, o PRI, o governo suíço e a empresa de consultora OnValues; 4. O Guidelines for Responsible Investing in Food Commodities foi lançado em 2012 pela Interfaith Center on Corporate Responsibility, uma coalização de investidores e acionistas; 5. Finalmente, o Responding to 'land grabbing' and promoting responsible investment in agriculture foi lançado em 2011, pelo International Fund for Agricultural Development (IFAD), uma agência da ONU.

Após este panorama, faz-se necessário indicar algumas reflexões e eixos de discussão que permitem o aprofundamento em alguns dos objetivos desta pesquisa. Borras, Franco e Wang (2013), ao analisar diferentes iniciativas de regulação para os investimentos em terra, identificam a existência de tendências de posicionamentos diferentes quanto ao tratamento dos investimentos em terra oferecidos. Diante disto, os autores argumentam que há três principais posições sobre o assunto: parte das abordagens sobre o tema defende a regulação dos investimentos com vistas a facilitar as transações; outra parte defende a regulação para mitigar os impactos negativos e maximizar oportunidades resultantes dos investimentos; e outra, defende a regulação dos investimentos para parar e reverter land grabbing.

${ }^{9}$ O TIAA-CREF é uma sigla em inglês que se refere à Associação de Seguros e Rendas Vitalícias de Professores Americanos. Trata-se de um fundo de pensão dos EUA que tem chamado a atenção pelos seus grandes investimentos em terra, dados em um contexto mais amplo de criação de diversos novos instrumentos financeiros, cujo objetivo é reduzir riscos em seus investimentos (WHITE, BORRAS JR., et al., 2012). 
Os autores concordam que as principais diretrizes para regulação sobre investimentos em terra, como as do Banco Mundial e da FAO, tendem a defender que se deve mitigar os impactos dos investimentos e maximizar as oportunidades oferecidas por tais. Em contraposição, grupos transnacionais da sociedade civil organizada, como a La Via Campesina e determinadas ONGs, tendem a defender que os investimentos devem ser regulados para parar e reverter land grabbing. Ainda que estas posições não sejam fixas, são tendências encontradas pelos autores a partir de revisão de literatura, observação de políticas públicas e participação em discussões políticas. O modo de ver o fenômeno parece estar relacionado diretamente a diferentes concepções do que é desenvolvimento e sobre que modelo de desenvolvimento se defende. Os argumentos destes autores estão organizados na tabela 2. 
Tabela 2 - Tendência de posicionamento sobre como tratar os investimentos estrangeiros em terra

\begin{tabular}{|c|c|c|c|}
\hline $\begin{array}{c}\text { Tendências/ } \\
\text { Posições }\end{array}$ & $\begin{array}{l}\text { Regular para facilitar } \\
\text { investimentos }\end{array}$ & $\begin{array}{l}\text { Regular para mitigar impactos } \\
\text { negativos e maximizar } \\
\text { oportunidades }\end{array}$ & $\begin{array}{l}\text { Regular para parar } \\
\text { e reverter land } \\
\text { grabbing }\end{array}$ \\
\hline $\begin{array}{l}\text { Principais } \\
\text { ideias }\end{array}$ & $\begin{array}{c}\text { Entendem que } \\
\text { investimentos de } \\
\text { larga escala em terra } \\
\text { são desejáveis e } \\
\text { defendem o } \\
\text { fortalecimento dos } \\
\text { direitos à propriedade } \\
\text { privada, dos padrões } \\
\text { ambientais e } \\
\text { trabalhistas, a } \\
\text { consulta à } \\
\text { comunidades locais e } \\
\text { o uso de } \\
\text { instrumentos } \\
\text { internacionais de } \\
\text { governança como } \\
\text { forma de facilitar a } \\
\text { acumulação de } \\
\text { capital. }\end{array}$ & $\begin{array}{l}\text { Destacam a inevitabilidade } \\
\text { dos investimentos em larga } \\
\text { escala em terra e a } \\
\text { impossibilidade de haver } \\
\text { políticas de distribuição de } \\
\text { terra e desenvolvimento rural } \\
\text { para promoção do } \\
\text { desenvolvimento baseado na } \\
\text { agricultura de pequena escala. } \\
\text { É uma perspectiva “win-win” } \\
\text { (ganho-ganho). Defendem } \\
\text { que os investimentos podem } \\
\text { ser ótimas oportunidades de } \\
\text { desenvolvimento, ao passo } \\
\text { que se fortaleça direitos de } \\
\text { posse das populações, direitos } \\
\text { ambientais e trabalhistas, } \\
\text { maior consulta às }\end{array}$ & $\begin{array}{l}\text { Entendem que tais } \\
\text { investimentos } \\
\text { servem à ampliação } \\
\text { da acumulação de } \\
\text { capital e para trazer } \\
\text { lucro à } \\
\text { corporações. } \\
\text { Defendem os } \\
\text { direitos das } \\
\text { pessoas, do meio } \\
\text { ambiente, } \\
\text { consultas às } \\
\text { comunidades e } \\
\text { transparência. A } \\
\text { ideia é que a } \\
\text { governança } \\
\text { exponha e oponha, } \\
\text { pare e então } \\
\text { fenômenta o }\end{array}$ \\
\hline $\begin{array}{l}\text { Principais } \\
\text { atores }\end{array}$ & Banco Mundial & $\begin{array}{l}\text { Partes da FAO, ONGs (como a } \\
\text { Oxfam), provedores de ajuda, } \\
\text { agências de desenvolvimento, } \\
\text { organizações comunitárias e } \\
\text { alguns governos. }\end{array}$ & $\begin{array}{c}\text { La Via Campesina e } \\
\text { outros movimentos } \\
\text { campesinos }\end{array}$ \\
\hline
\end{tabular}

Fonte: elaboração própria a partir de dados de Borras, Franco e Wang (2013). 


\subsection{1.}

\section{A iniciativa 'Principles for Responsible Agricultural Investment that Respects Rights, Livelihoods and Resources' (PRAl)}

O Principles for Responsible Agricultural Investment that Respects Rights, Livelihoods and Resources (PRAI, sigla em inglês) é uma iniciativa global de regulação dos investimentos em terra, expressa em um documento constituído por 7 princípios. Os princípios recomendados neste documento se baseiam em estudos e experiências anteriores das instituições envolvidas na sua formulação, e, sobretudo, no estudo feito pelo Banco Mundial, iniciado em 2009 e lançado em 2011 pelo relatório Rising Global Interest in Farmland: can it yield sustainable and equitable benefits? Estes princípios são um misto de "melhores práticas", diretrizes, quadros de governança e códigos de conduta para diversos stakeholders, como corporações ou governos, que estimulam investimentos agrícolas responsáveis.

O ponto de partida do PRAI é a ideia de que investimentos, tanto de natureza pública quanto privada, são necessários para aumentar a produtividade da produção de pequenos agricultores e, dessa forma, contribuir para alcançar crescimento econômico e redução da pobreza dos locais que recebem estes investimentos, especialmente nos países com baixa renda. Os investimentos privados são vistos como complementos aos recursos públicos, que trazem benefícios significativos para os países que os recebem, como acesso a capital, tecnologia e conhecimento, geração de emprego e o aumento de produtividade.

Ao mesmo tempo, o PRAI reconhece a importância de que os investimentos respeitem os direitos dos presentes usuários de terras, água e outros recursos, protejam e melhorem as formas de vidas das famílias e comunidades próximas e não prejudiquem o meio ambiente. Dessa forma, admite-se que estes investimentos podem trazer riscos se, segundo o documento, implementados de 
forma a negligenciar as melhores práticas recomendadas. Sobretudo, argumentase que locais em que os direitos das populações não estão bem consolidados e definidos, em que a governança é fraca ou que os afetados pelos investimentos não tenham voz, os investimentos podem representar maiores riscos. O PRAI admite riscos relacionados a reassentamentos, enfraquecimento ou negação de direitos das comunidades, corrupção, redução da segurança alimentar, destruição ambiental, perda de acesso à terra, além de outros riscos políticos e sociais.

O objetivo deste documento parece ser, assim, maximizar os benefícios e oportunidades que, como se argumenta, seguem dos investimentos, e mitigar os riscos a estes associados. O primeiro princípio do PRAI refere-se ao respeito aos direitos à terra e aos recursos naturais existentes, sejam estes "estatutário ou consuetudinário, primário ou secundário, formal ou informal, grupal ou individual" (FAO, IFAD, UNCTAD, WORLD BANK GROUP, 2010, p. 2). Porém, para que haja o reconhecimento destes direitos, são necessárias algumas medidas, como, por exemplo, a identificação de todos portadores de direitos e o reconhecimento legal de todos os direitos e usos, assim como iniciativas de demarcação e registro destes, dentre outras medidas relacionadas. O segundo princípio prega que investimentos não prejudiquem a segurança alimentar (em termos de disponibilidade de alimentos, acesso, utilização e estabilidade) dos locais que recebem os investimentos, mas que esta seja fortalecida.

A garantia de que haja para os investimentos em terra e outros recursos, transparência, boa governança e um ambiente propício para negócios, é o foco do terceiro princípio. Tal garantia é fundamental para o aumento da produtividade dos negócios, aqui relacionados ao progresso econômico dos países. Estes elementos favorecem diversos envolvidos nestes processos, segundo o documento: comunidades e indivíduos serão mais capazes de entender seus direitos e obrigações; governos poderão atrair melhores investimentos para locais com potencial para desenvolvimento, e definir os melhores investimentos em termos de impactos sociais para os locais; e investidores poderão negociar direto com aqueles que possuem direitos, em vez de tratar com o governo. Cabe notar que o documento defende ainda uma série de práticas que podem ser adotadas e 
processos que devem ser melhorados como forma de atrair investimentos para os países, principalmente sob a forma de recomendações aos governos locais.

O quarto princípio, por sua vez, defende que todos aqueles que são materialmente afetados devem ser consultados e participar dos processos. Os acordos firmados devem ser documentados e assegurados. O documento recomenda que o investimento deva acontecer com a participação dos envolvidos, de maneira consistente com a visão sobre desenvolvimento da população local. O quinto princípio recomenda que os investidores garantam que os investimentos sejam feitos de maneira responsável. Isto significa que respeitem as leis vigentes no país que recebe os investimentos (idealmente, que considerem também o direito internacional), reflitam as melhores práticas da indústria (como transparência e responsabilidade), sejam viáveis economicamente e resultem em valores duráveis que possam ser compartilhados pelos envolvidos e afetados. Em sexto, está a recomendação de que os investimentos sejam sustentáveis socialmente, isto é, que gerem impactos sociais e distribucionais positivos e não aumentem a vulnerabilidade dos locais receptores. E em sétimo, recomenda-se que os investimentos sejam sustentáveis ambientalmente. Desta forma, defende-se que os impactos ambientais de um projeto sejam quantificados e que se use recursos de forma sustentável, minimizando riscos ou mitigando impactos negativos.

Estes princípios estão relacionados a diversos tópicos da economia política internacional, desenvolvimento rural e agricultura e investimentos, dentre outros, e se baseiam em certas premissas para desenvolver seus argumentos. No entanto, diversas destas premissas são controversas. Algumas destas configuram o que alguns autores têm tratado como mitos, que nem sempre aparecem de maneira explicita na elaboração do documento.

Por meio da leitura e exposição dos princípios elaborados pelo PRAI, identifica-se como elemento central neste documento o discurso da "necessidade" de haver investimentos em agricultura para aumentar a produtividade, melhorar o bem-estar das pessoas e reduzir a pobreza rural. Este discurso possui diversas 
implicações, que tornam essencial notar e problematizar as premissas sobre as quais estes se baseiam, relacionadas a diversos aspectos dos land grabs.

O discurso de que através dos investimentos se pode melhorar a renda rural e diminuir a insegurança alimentar global acentuada com a crise alimentar global, parte da premissa de que a pobreza e a fome seriam resultados da falta de investimentos em agricultura, e os investimentos recentes em terra devem, dessa forma, ser vistos como "soluções" para este "problema". Neste processo, não se questiona os tipos de desenvolvimento que cada comunidade afetada pelos investimentos defendidos deseja, mas parte-se do pressuposto que o desenvolvimento econômico capitalista é um sucesso a ser seguido pelos demais países (BORRAS JR e FRANCO, 2010). Diante disto, a pobreza do mundo rural é colocada como resultado da incapacidade dos Estados pobres de seguir este caminho e se desenvolver, que deve, por conseguinte, se comprometer com medidas que tanto melhorem as condições locais para os investidores, quanto assegurem os direitos de posse da terra a todos. Este discurso possui diversas implicações, que tornam essencial notar e problematizar as premissas sobre as quais estes se baseiam, relacionadas a diversos aspectos dos land grabs.

A agricultura precisa, nesta perspectiva, de investimentos, em especial, investimentos estrangeiros, feitos em larga escala e preferencialmente por corporações, para que haja maior competitividade na cadeia global de produção agrícola (TNI, 2013). Conforme Mcmichael (2012), a capitalização agroindustrial destas terras representa uma solução para estes problemas: o empenho em modernizar a agricultura e em transformar a produção de alimentos pelo modelo agroindustrial, em uma era de financeirização, se mostra uma oportunidade de investimento para o capital, para seguir acumulando capital, em concordância com Harvey.

Nota-se a existência de uma ideologia que unifica diversos discursos e iniciativas, que defendem a importância destes investimentos: a de que as terras ocupadas ou acessadas por estes capitais têm pouco rendimento e são subutilizadas ou vazias (MCMICHAEL, 2012). Esta ideia é fundamental para a 
defesa dos investimentos em terra, porém, é amplamente criticada pela academia e por movimentos sociais. A noção de terras disponíveis é vaga e abre espaço para ambiguidades e diferentes interpretações com relação, por exemplo, à importância social e ambiental destas terras. Usos da terra que não envolvem dinâmicas de mercado, por exemplo, tendem a ser desvalorizadas, apesar do valor destas atividades para a subsistência de determinados povos (BORRAS JR e FRANCO, 2010).

Tal discurso sobre "necessidade" de haver investimentos em agricultura para aumentar sua eficiência, ao defender investimentos em larga escala, capitais intensivos e controlados por corporações como as únicas soluções possíveis para a fome mundial e a pobreza rural, contribui significativamente para obscurecer os modelos alternativos de investimento e até de desenvolvimento que existem em diversas regiões. Em contraposição ao argumento de que faltam investimentos em agricultura, o relatório do TNI (2013) afirma a existência de uma pluralidade ${ }^{10} \mathrm{de}$ formas de investimentos alternativos que contrapõem esta visão estreita, como, por exemplo, a agroecologia, que tem crescido sobretudo na América Latina (TNI, 2013).

A maior parte dos investimentos hoje em agricultura são feitos pelos próprios agricultores, e os pequenos produtores são responsáveis por produzir a maior parte dos alimentos consumidos localmente em diversas regiões do mundo. Além disso, há um consenso científico, segundo Mcmichael (2012), de que produções de pequena escala produzem tanto quanto, se não mais que, produções de larga escala, industrializadas. Disto decorre que os argumentos em favor de investimentos de alto valor para integrar as produções às cadeias globais de produção são controversos: em defesa da segurança alimentar, se desestabiliza as bases da alimentação hoje em diversas regiões.

\footnotetext{
${ }^{10}$ Para outros exemplos, ver TNI. (2013). The Global Land Grab: a primer. TNI Agrarian Justice Programme.
} 
Olivier de Shutter (2011) afirma que a regulação de land grabbing proposta pelo Principles for Responsible Agricultural Investment resume o debate sobre a regulação do fenômeno somente aos prós e aos contras destes investimentos e à como lidar com tais. O que está por trás desta abordagem é a ideia de que tais investimentos são inevitáveis. Ao mesmo tempo, de acordo com Borras \& Franco (2010), esta abordagem pensa as implicações para as populações e para o meio ambiente como riscos possíveis, efeitos colaterais dos investimentos, mas que não são graves o suficiente para questionar os investimentos em terra como solução para a pobreza. Estes são riscos que podem ser administrados afim de se atingir um objetivo maior.

Esta perspectiva 'inevitabilista' impede de se pensar formas alternativas de desenvolvimento e utilização de terra, mais justas e sustentáveis. Diante disto, Shutter (2011) defende a necessidade de ampliação do debate para se pensar modelos alternativos de desenvolvimento. Para o autor, os objetivos colocados pelo PRAI, de reduzir a pobreza no mundo rural, poderiam ser alcançados de forma mais efetiva pelo acesso mais equitativo a terras, e, por isso, defende uma reforma agrária. É primordial notar a virada metodológica proposta pelo autor, que fomenta pensar não apenas em como produzir mais, como faz o PRAI, mas questionar como aumentar a produtividade com justiça social. Estes argumentos revelam a importância de se pensar os movimentos que se contrapõem a esta visão e tratamento defendidos por esta regulação, como os movimentos campesinos, como será visto adiante.

Outra premissa fundamental que baseia a defesa dos investimentos em agricultura pelo PRAI, e que está diretamente ligada ao exposto acima, é que estes investimentos devem ser feitos em nome do aumento da produtividade agrícola para alimentar o mundo. Isto é, a segurança alimentar é utilizada como justificativa para os land grabs. Esta observação está presente também no trabalho de Mcmichael (2012), que afirma que os processos que resultam em land grabbing vêm acompanhados pela ideologia dos "cercamentos em nome da humanidade", isto é, em nome da escassez de alimentos e da busca por fontes de energias alternativas. Ambos dependem do acesso a terras em todo o globo. Nesta 
abordagem, a crise de acumulação deste período impulsiona e justifica investimentos em terra, em nome, especialmente, da escassez de alimentos e de energias alternativas.

A defesa da "necessidade" de haver investimentos em agricultura está associada, por conseguinte, às dinâmicas da economia global, em que se liga os investimentos a uma dinâmica inevitável e irreversível da economia global e não se problematiza as contradições que originam as crises. A narrativa de crises é usada como justificativa para legitimar os investimentos em terras e recursos relacionados, pois representariam soluções para estas. A proposta neste trabalho é descortinar os conflitos por trás deste discurso e evidenciar que é o modelo de produção em que os land grabs são feitos que deve ser pensado como causa das crises, como desenvolvido no primeiro capítulo. Land grabbing se expressa, em grande parte, como resultado destas crises, e não "solução". A própria crise alimentar global e a convergência de múltiplas crises devem ser vistas como formas de questionar o paradigma de desenvolvimento predominante: as crises revelam que o livre mercado falhou em garantir segurança alimentar nos países em desenvolvimento, sobretudo naqueles que seguiam as recomendações do Banco Mundial, conforme afirma McKeon (2013).

Neste processo em que os investimentos são colocados como um "bem comum”, necessários para resolver a pobreza e a fome da humanidade, há outra consequência substancial a ser observada: o obscurecimento ou o disfarce dos prejuízos causados aos habitantes das terras que recebem os investimentos, que são frequentemente expulsos ou perdem o controle de suas terras. Conforme Mcmichael (2012), enquanto para investidores as terras são frequentemente vistas pelos seus valores monetários, para os seus habitantes, entretanto, estas possuem outros valores. Terras comuns ou ocupadas significam para muitos indivíduos a possibilidade de subsistência e de ter seus modos de vidas preservados, além do valor espiritual, cultural e o associado às suas famílias e às suas histórias que possuem.

Once the concept of a 'global commons' becomes the modus operandi, agency, government and investor acquisition of land devalues 
its local cultural and ecological functions. Eviction of 'unproductive' populations becomes the basis of 'rational planning' - driven by claims for increased productivity, debt-reduction, export enhancement and rural development (MCMICHAEL, 2012, p. 693).

Defender os investimentos em terra, quer dizer, os land grabs como práticas para o "bem comum", significa defender que estes representam um jogo de benefícios mútuos, com resultados positivos tanto para os investidores nacionais e internacionais, quanto para os produtores locais. O Banco Mundial já defendia a lógica "win-win" (ganho-ganho) em outros relatórios lançados anteriormente à sua parceria com as agências do sistema ONU para formulação do PRAI.

Por esta lógica, argumenta-se que os pequenos agricultores podem se beneficiar da sua integração às cadeias globais de agronegócio - globalização e agronegócio podem ser oportunidades para os pobres (OYA, 2009). Carlos Oya analisa o World Development Report, lançado em 2008 pelo Banco, o primeiro relatório exclusivamente dedicado a agricultura em 25 anos, e admite que certas oportunidades podem se abrir para o desenvolvimento de alguns pequenos agricultores. O maior problema de tal lógica presente neste relatório e na iniciativa de regulação em análise, é que ela negligencia e silencia lutas de poder e relações conflituosas entre os participantes das cadeias de valor global, intrínsecas às estruturas do modo de produção vigente (OYA, 2009).

O PRAI admite que há riscos associados a estes investimentos quando não observadas as melhores práticas recomendadas pelo documento. Quando bem administrados, os investimentos representam "oportunidades" para o desenvolvimento local. Dessa forma, o documento atua de forma discursiva na legitimação das práticas de land grab ao defender que estes podem sim ser feitos de forma responsável.

Neste argumento, ocorre a responsabilização de determinados atores, como governos e até as populações locais, pelos riscos ou efeitos negativos decorrentes das transações. A 'fragilidade' da governança de terras em determinados locais, a não consolidação ou definição dos direitos das populações ou a 'falta de 
conhecimento' das populações locais quanto aos seus direitos e obrigações, e a falta de voz de determinados grupos sociais afetados pelos investimentos, constituem razões para que os investimentos desencadeiem consequências negativas. Nesse sentido, o PRAI exterioriza as implicações negativas destes investimentos e responsabiliza a 'fragilidade' daqueles responsáveis pela administração da terra por tais.

Estes argumentos levam ainda a outro ponto central dos princípios elaborados pelo PRAI: a importância do papel desempenhado pelo Estado para a criação das condições necessárias para a expansão do capital. Tal iniciativa de regulação defende que transparência, boa governança e um ambiente propício para negócios devem ser objetivos perseguidos pelos Estados nacionais para que haja maior aproveitamento das oportunidades trazidas pelos investimentos.

As "melhores práticas" promovidas pelo PRAI estão associadas, nesse sentido, aos processos elucidados por Stephen Gill e seu conceito de novo constitucionalismo. Um dos objetivos centrais do novo constitucionalismo é fazer os Estados se adequarem à disciplina de mercado, sobretudo através da institucionalização ou da proteção da liberdade de movimento de entrada e saída do capital. Instituições internacionais, como o Banco Mundial, promovem a reformulação de alguns elementos dos Estados de modo a criar ambientes mais estáveis e favoráveis à entrada de capitais externos nos países, como defendido particularmente no terceiro princípio do PRAI. Os Estados são estimulados a agir como se pertencessem ao mercado, e a fazer reformas em nome de suas credibilidades e do estabelecimento de boas condições políticas para atrair investimentos. O novo constitucionalismo atua de modo a institucionalizar proteções às empresas e investidores, em detrimento de grande parte da população (GILL, 2014).

Cabe ressaltar que o relacionamento dos Estados com o capital ocorre de maneira complexa, não podendo ser aquele pensado somente como um instrumento em favor da classe dominante. As ideias gramscianas quanto à 
combinação de coerção e consenso são chaves para entender este relacionamento e a forma como Banco Mundial tem atuado historicamente (PEREIRA, 2009).

Em síntese, este trabalho defende que as implicações negativas destes investimentos devem ser pensadas em conexão com a assimetria de poder existente entre grandes investidores e as populações afetadas, isto é, as relações de poder e interesses que existem por trás dos investimentos, e não em termos de má governança. Estes tipos de medidas, que têm como propósito priorizar ações estatais que favoreçam a circulação de capital e ofereçam boas condições a estes, limitam a participação democrática das massas sobre aspectos centrais das economias, conforme afirma Gill.

O tema da posse de terras no PRAI para administração de riscos também deve ser sublinhado. Determinados princípios desta iniciativa de regulação afirmam a necessidade de haver respeito aos direitos de posse e uso de terras existentes hoje, para que os investimentos tenham resultados positivos para os locais e as populações a que se direcionam. Porém, admite-se que o reconhecimento destes direitos requer primeiramente a identificação, o registro e então o reconhecimento legal de todos estes.

Este documento parece concordar com a ideia de que as pessoas são expulsas de suas terras porque não possuem os direitos de propriedade formais sobre tais, e por isso são necessárias medidas para prover 'segurança de posse da terra' (land security) para estes indivíduos. Ademais, entende-se que a falta de títulos de propriedade representa insegurança ou riscos para os investidores que, desta forma, são desencorajados a investir nestes locais. Estes pressupostos justificam a defesa do PRAI quanto à necessidade de asseguração da 'segurança de posse da terra' nos locais alvos dos investimentos por meio dos direitos de propriedade.

Este tema constitui, todavia, um amplo e disputado debate nos estudos sobre desenvolvimento e mundo rural, posto que há diferentes perspectivas quanto aos direitos de propriedade. O TNI (2013) defende que esta questão deve ser vista em perspectiva histórica crítica, considerando o histórico dos assuntos relacionados à 
terra e às políticas agrárias. Na literatura sobre políticas de terras, o termo "segurança" significa fornecer, promover ou proteger os direitos de propriedade do dono ou do usuário exclusivo de determinada terra. Nesta perspectiva, dois aspectos se destacam. Em primeiro lugar, "segurança" implica no estabelecimento de direitos de propriedade privada e individual e reforça uma visão conservadora que reduz a terra a uma coisa, isto é, a uma mercadoria intercambiável. O processo de mercantilização da terra a reduz a algo com valor meramente econômico, em detrimento de seus outros valores. Em segundo lugar, a noção de "segurança" é ampla e pode sugerir seguranças tanto legítimas quanto ilegítimas e que sejam a favor dos pobres ou não. No contexto dos land grabs, segurança tende a servir para a garantir os direitos dos capitais transnacionais investidos em terra (TNI, 2013).

Apesar do PRAI defender que todos aqueles que são materialmente afetados pelos investimentos em terra e recursos relacionados devem ser consultados e participar das dinâmicas, e que os investimentos devam acontecer de maneira consistente com a visão sobre desenvolvimento da população local, este documento foi acusado de falta de participação da sociedade civil, de modo que intensas críticas conduziram ao seu não endossamento pelo Comitê de Segurança Alimentar Mundial (CFS). A participação foi incorporada a esta iniciativa e se faz presente em diversas passagens do documento, porém, esta parece não ter sido incorporada à sua prática. A participação como um discurso, como mencionado anteriormente, tem sido utilizada como uma forma de despolitizar a economia, ao evitar contestações e retirar de discussões democráticas as estratégias de política econômica.

O Banco Mundial, mais do que apenas um agente financeiro, é um ator político central no cenário internacional, que se projeta como uma agência comprometida com o compartilhamento de conhecimento, com legitimidade "como fonte de dados, disseminador de ideias, produtor de análises comparativas e guia em matéria de políticas de desenvolvimento" (PEREIRA, 2017). Esse Banco se destaca na produção de estudos sobre os investimentos estrangeiros em larga-escala em terras, que vão, inclusive, prover as bases para a elaboração do 
PRAI, em conjunto com a FAO, UNCTAD e IFAD. Diversos dos argumentos presentes neste documento, como a ideia de que há terras disponíveis para receber os investimentos, que estão vazias, subutilizadas ou que possuem pouca produtividade, já estavam presentes em estudos anteriores realizados pelo Banco Mundial, como este. Antes do lançamento do PRAI, o Banco já era um expoente da perspectiva "regular para facilitar", através dos seus estudos, que veem os land grabs como positivos. Em relação ao tema da agricultura, o Banco está fortemente associado à defesa de políticas fundiárias de cunho neoliberal, como mencionado no capítulo anterior, quanto à retomada, à elaboração e à implementação de uma agenda de políticas agrárias pelo BIRD.

Desse modo, entende-se que o reconhecimento nacional e internacional da legitimidade dos estudos produzidos por este ator, aponta para a importância da análise da iniciativa de regulação de land grabbing liderada por este. Isto indica ainda que não somente o PRAI em si é importante para esta análise, mas também outros estudos elaborados anteriormente sobre o tema, que já representam uma forma de ter influência sobre o assunto e apontam para uma forma de tratá-lo.

\subsection{2.}

\section{A iniciativa 'Voluntary Guidelines on the Responsible Governance of Tenure of Land, Fisheries and Forests in the Context of National Food Security' (VG)}

Os land grabs que têm crescido em todo o mundo nos últimos anos chamaram a atenção mundial para a governança da terra e os conflitos decorrentes dos investimentos neste recurso e em outros relacionados, como foi discutido. A terra começou a ganhar destaque em debates internacionais e, em particular, nas discussões das agências da ONU, sobretudo a partir da mobilização da sociedade civil para denunciar estas práticas. A crise alimentar global já mostrava a existência de um vácuo político neste âmbito, dada a ausência de um órgão para 
tratar com autoridade e de maneira inclusiva de assuntos relacionados a alimentos e terra globalmente. As decisões e iniciativas, no que tange a estas temas, estavam historicamente restritas ao âmbito da Organização Mundial para o Comércio (OMC), Banco Mundial e outros grupos de economias fortes, como o G8 e o G20, além de empresas transnacionais e atores financeiros (MCKEON, 2013), e, no período recente, diferentes abordagens emergiram disputando este vácuo.

A FAO destaca-se nesta disputa sobre a governança da terra, sobretudo após a reforma do seu Comitê de Segurança Alimentar Mundial (CFS), iniciada em 2009. A FAO é uma agência especializada da Organização das Nações Unidas (ONU), criada em 1945, responsável por diversas questões da agenda política internacional, constituindo-se como um espaço intergovernamental para negociações de políticas relativas a temas agrícolas, como segurança alimentar e nutricional. A reforma no seu comitê teve o intuito de transformá-lo em um fórum de política global inclusivo e com autoridade sobre segurança alimentar, com vistas a garantir alimentos à população mundial. O ideal inclusivo deste comitê foi buscado já em sua formulação, contando com forte participação da sociedade civil, que teve diversas de suas reivindicações ouvidas (MCKEON, 2013).

No período em que as práticas de land grab se intensificavam, a FAO já estava trabalhando na proposta de formulação de diretrizes para a governança da terra. O processo se deu inicialmente pela realização de consultas públicas para a elaboração da proposta, no período de 2009 a 2010. Após a reforma do CFS e forte pressão da sociedade civil, as diretrizes passaram a ser negociadas no âmbito deste comitê. Nora McKeon (2013) afirma que o formato renovado do comitê possibilitou que decisões políticas fossem tomadas em sessões em que a sociedade civil e movimentos sociais fossem participantes completos, o que contribuiu para que a discussão destas diretrizes, neste âmbito, resultasse em processos mais inclusivos.

O Voluntary Guidelines on the Responsible Governance of Tenure of Land, Fisheries and Forests in the Context of National Food Security (VG) foi aprovado em 2012, pelo CFS. Estas diretrizes de caráter voluntário afirmam o propósito de 
contribuir para erradicação da pobreza e da fome, e centram suas recomendações na defesa do desenvolvimento sustentável, na promoção dos direitos de posse e no acesso equitativo aos recursos terra, pesqueiros e florestas.

As diretrizes representam um avanço na governança da terra e recursos a ela relacionados, sobretudo pela consideração deste documento de certos aspectos que vem sendo historicamente reivindicados por lutas sociais, como o reconhecimento de diferentes valores atribuídos aos recursos naturais em questão e referência aos Direitos Humanos. O próprio documento enfatiza a sua conformidade com os Objetivos de Desenvolvimento do Milênio, em especial no que diz respeito aos Direitos Humanos e aos direitos de posse, e destaca que suas diretrizes foram formuladas a partir de um processo inclusivo de consultas públicas com a sociedade civil, academia, setores privados e públicos (FAO, 2012), que aumentam a percepção de legitimidade desta iniciativa (MARGULIS e PORTER, 2013). Antes de destacar alguns destes principais aspectos, cabe ressaltar o objetivo estabelecido pelas diretrizes:

"[...] to improve governance of tenure of land, fisheries and forests. They seek to do so for the benefit of all, with an emphasis on vulnerable and marginalized people, with the goals of food security and progressive realization of the right to adequate food, poverty eradication, sustainable livelihoods, social stability, housing security, rural development, environmental protection and sustainable social and economic development." (FAO, 2012, p. 1).

As diretrizes se declaram complementares às leis nacionais e internacionais, e se direcionam aos Estados e agências; autoridades judiciais; governos locais; usuários dos recursos naturais em questão e comunidades em geral; sociedade civil organizada; academia; setores privados; e outros indivíduos (FAO, 2012).

Os princípios do documento informam sobre os deveres do Estado e atores não estatais no que tange aos direitos de posse de terra. Estes são postulados em textos direcionados significativamente aos Estados, a quem cabe, em particular: reconhecer e respeitar todos os titulares legítimos e seus direitos de posse; salvaguardar os direitos legítimos de posse diante de ameaças e infrações; 
promover e facilitar o gozo dos direitos legítimos de posse; proporcionar o acesso à justiça para lidar com violações dos direitos legítimos de posse; prevenir as disputas relacionadas com a posse, os conflitos violentos e a corrupção. Estes devem ser acompanhados dos seguintes princípios: dignidade humana; não discriminação; equidade e justiça; igualdade de gênero; enfoque holístico e sustentável; consulta e participação; Estado de Direito; transparência; prestação de contas; e melhoria contínua (FAO, 2012).

De maneira em parte semelhante à iniciativa de regulação vista anteriormente, estas diretrizes entendem que a governança fraca é uma das principais fontes de problemas com a posse de terras. Falhas na proteção de direitos de posse e práticas de corrupção, por exemplo, são sintomas de fraca governança que contribuem para a pobreza e a fome de diversas populações. Por isto, este documento volta-se à defesa de medidas que protejam os direitos de posse da terra e outros recursos associados, porém, em termos diferentes do PRAI. As diretrizes entendem que a forma com que os indivíduos têm acesso a estes recursos e os controlam são pontos chaves para pensar perspectivas de desenvolvimento e evitar deficiências, que são fontes de conflito e degradação ambiental.

O Voluntary Guidelines sugere a necessidade de os Estados garantirem políticas de reconhecimento e respeito às posses de terra costumeiras, que não estão no momento protegidas pelas leis, como posses de populações indígenas e outras posses e controles sobre os recursos que ocorrem de modo informais. De acordo com as diretrizes, os Estados devem garantir que os direitos de posses destes povos sejam protegidos, respeitando-se os significados sociais, culturais, espirituais, econômicos, políticos e ambientais que a terra, recursos pesqueiros e florestas possuem para diversas populações, grupos e indivíduos. O respeito a estas posses e significados deve ocorrer também em casos em que os Estados são os donos ou controlam a terra, recursos de pesca ou floresta, em conformidade com os objetivos sociais, econômicos e ambientais. 
Comunidades e povos indígenas ocupam, desse modo, lugar central nas diretrizes, que reconhecem os diferentes valores que as terras possuem para diferentes povos. Nesse sentido, esta abordagem vai além daquela analisada anteriormente, que vê apenas o valor econômico destes recursos e requer que as terras sejam transformadas em propriedade privada, reconhecidas legalmente, para que os direitos de posse sejam reconhecidos. A sociedade civil organizada sublinha ainda, através de um relatório, a importância deste documento adotar uma visão holística da posse da terra, que reconhece que os recursos naturais e os seus usos são interconectados (CSM4CFS, 2016).

As diretrizes enfatizam a necessidade de consulta e participação efetiva de todos aqueles envolvidos e afetados por políticas, leis e processos que estejam sendo desenvolvidos e implementados sobre estes recursos. Estas reforçam, em particular, a participação de tais comunidades e povos indígenas e mulheres, e especificam formas de consultas às comunidades. Destaca-se, ainda, a preocupação do documento com questões de gênero na elaboração de políticas públicas. As recomendações sugerem que a equidade de gênero seja respeitada. Isto é, tanto homens quanto mulheres devem ser incluídos nos processos de desenvolvimento e implementação de tais elementos e possuir os mesmos direitos. Os Estados devem desenvolver políticas que visem o uso e controle de tais recursos naturais, que são públicos, e ainda promover distribuição equitativa dos benefícios dos recursos que pertencem aos Estados.

Interessa especialmente ao desenvolvimento deste trabalho uma parte específica deste documento, elaborada para tratar da governança destes recursos em transferências ou realocação de direitos existentes, sejam estas por vias voluntárias ou involuntárias, como mercados, investimentos, reajustes, reformas redistributivas ou expropriação. Esta seção se conecta desta forma diretamente à recente corrida global por terras, ainda que, conforme mencionado, este documento não tenha sido criado em reação direta ao fenômeno.

Esta abordagem argumenta em favor da promoção dos mercados de direitos de uso e propriedade da terra, recursos pesqueiros e florestas. Recomenda-se que 
os Estados ajam como facilitadores destas transações de mercado, sobretudo reconhecendo e facilitando aquelas 'justas', 'transparentes' e 'eficientes', de modo a promover condições iguais e oportunidades para benefício mútuo destas transações, que diminuem conflito e instabilidade. Defende-se que estes investimentos contribuem para a expansão das oportunidades econômicas e que são os Estados os responsáveis por tomar medidas para prevenir impactos negativos para comunidades locais ou outros grupos, por eles ocasionados, tais como concentração de terra, especulação com terra e abusos sobre posses costumeiras. Neste ponto, o VG se aproxima da crítica feita ao PRAI quanto à responsabilização dos Estados, visto que também exterioriza as implicações negativas destes investimentos e responsabiliza a 'fragilidade' daqueles responsáveis pela administração da terra por tais.

Os investimentos de origem pública ou privado são vistos como essenciais para melhorar a segurança alimentar, em um discurso que enfatiza a "necessidade" dos investimentos para o desenvolvimento. Assim como no PRAI, a ideia de "necessidade" dos mercados está relacionada a formas de disciplinamento pelo qual se faz parecer que isto é necessário para o bem de todos, ainda que não o seja e represente os interesses apenas de determinado grupo da sociedade. Ademais, esta perspectiva defende que uma governança responsável dos recursos deve encorajar estes investimentos responsáveis, visto que contribuem para a erradicação da pobreza, a segurança alimentar, usos sustentáveis dos recursos naturais em questão, o desenvolvimento rural, a criação de empregos, dentre outros benefícios. O documento produz, assim, uma narrativa que afirma que os investimentos nestes recursos podem sim ser feitos de forma responsável, que não cause prejuízos e despossessões de terras legitimas, que não degrade o meio ambiente e respeite os direitos humanos, e que, nesse sentido, legitimam estes investimentos. Deve-se ressaltar, entretanto, que na prática, tais investimentos têm tido efeitos negativos para populações expulsas de suas terras, e degradações ambientais. Quando se admite a apropriação de terras em larga escala, o controle sobre os grandes territórios continua nas mãos de poucos e grandes. 
Os pequenos produtores ocupam espaço especial nas recomendações deste documento, pois contribuem significativamente para a segurança alimentar, nutrição, erradicação da pobreza e resiliência ambiental. Nesta narrativa, os investimentos encorajados pelos Estados devem ser aqueles que reconheçam a importância dos pequenos produtores, diferenciando-o do PRAI, cujos princípios defendiam a modernização e incorporação dos pequenos agricultores às cadeias globais de produção de alimentos.

Além disso, o documento chama a atenção para reformas distributivas de terras, vistas como meio de facilitar o acesso equitativo à terra e desenvolvimento rural inclusivo. Reformas são encorajadas por motivações sociais, econômicos e ambientais, em que há alta concentração de terras combinada a alto nível de pobreza rural por falta de acesso à terra, e devem ser feitas respeitando-se os princípios do documento e leis nacionais. Expropriações, por sua vez, devem ser consideradas somente onde os direitos de posse são necessários para objetivos públicos.

Há um amplo reconhecimento que o Voluntary Guidelines é o principal documento internacional sobre a governança da terra existente, sobretudo por ter sido o primeiro a ser aprovado por todos os países signatários da ONU. Ainda que represente certos avanços para a governança da terra em direção a uma governança mais inclusiva, com participação de diversos atores envolvidos e afetados pelas dinâmicas do capital, fazendo referência aos Direitos Humanos e o reconhecimento de diferentes valores da terra para diferentes grupos, como ressaltado ao longo do capítulo, argumenta-se que este documento apresenta certas controvérsias, especialmente por não representar desafios à lógica do capital, como será visto nas próximas seções.

A análise deste documento suscita questionamentos que possuem como pano de fundo o debate sobre a capacidade desta e outras iniciativas de regulação voluntária dos investimentos em terra e elementos a ela relacionados de transformarem as ações dos atores a quem se direcionam. Alguns fatores e características das próprias iniciativas representam desafios às suas capacidades 
transformadoras. Mais que isso, a partir da análise destes documentos e das análises conjunturais e teóricas dos capítulos anteriores, este trabalho argumenta que tais iniciativas possuem um efeito produtivo de uma narrativa com consequências para o debate sobre desenvolvimento rural. Estes pontos serão retomados nas próximas seções deste trabalho.

\section{2.}

\section{Limitações das iniciativas de regulação voluntárias}

O capítulo anterior deste trabalho mostrou que governança global nos últimos anos foi marcada por mudanças nos atores envolvidos na governança global e mudanças nos mecanismos de governança utilizados, ligadas sobretudo à emergência de mecanismos mais flexíveis de governança, que focam em aumentar a habilidade e a disponibilidade dos atores envolvidos em agir em conformidade com tais regras.

As iniciativas voluntárias de governança dos investimentos em terra surgiram em um contexto mais amplo de criação de diversas outras iniciativas voluntárias para regulação de investimentos "responsáveis" em geral, promovidos tanto por governos quanto pelas próprias corporações transnacionais, e em um contexto de emergência de políticas neoliberais, que contribuíram para o fortalecimento destes novos mecanismos mais flexíveis (CLAPP, 2016). A elaboração daquelas foi motivada por preocupações quanto às potenciais consequências negativas destes investimentos. Em geral, as iniciativas vistas aqui buscam, através da regulação destes investimentos, maneiras de possibilitar que estes investimentos tenham efeitos positivos para seus investidores e os locais em que ocorrem, e, ao mesmo tempo, evitar suas consequências negativas.

Iniciativas de regulação voluntárias de investimentos de maneira geral, como o PRAI ou o VG, apresentam características que dificultam o vislumbre de mudanças reais no comportamento dos investidores. Visto que estas iniciativas 
foram adotadas recentemente, não se pode fazer uma avaliação completa dos seus desempenhos e impactos sobre aquilo que propõem. O intuito neste momento é refletir sobre a possibilidade de implementação destas iniciativas e suas capacidades reais de transformação das ações dos atores que alvejam. Quanto a isto, três aspectos, em especial, devem ser observados: a vagueza das proposições formuladas, a proliferação de iniciativas que competem entre si e as baixas taxas de participação que possuem. A vagueza diz respeito à formulação de princípios amplos e vagos quanto ao que exigem das partes a quem se direcionam, como faz o PRAI. Ainda que esta característica possa incentivar investidores a aderir às iniciativas, esta dificulta a sua implementação e o seu monitoramento (CLAPP, 2016).

A competição de diversas iniciativas de regulação de investimentos ocorre em um contexto mais amplo de crescente complexidade da governança global, em que regulações transnacionais tendem cada vez mais a interagir e se sobrepor sobre uma ampla gama de regimes internacionais e aglomerados de instituições (MARGULIS e PORTER, 2013). Esta complexidade pode, por vezes, gerar confusões. Conforme Margulis \& Porter (2013), o PRAI e o VG expressam algumas características desta complexidade. Em primeiro lugar, com relação à priorização de áreas diferentes pelos documentos - investimentos e posse da terra - que terminam por aproximar diferentes atores e regras. Em segundo lugar, estes documentos interagem também com outros amplos conjuntos de regulações regionais e internacionais, como os Direitos Humanos, códigos de condutas, acordos, entre outros, das leis domésticas dos países, que tornam o debate ainda mais intricado. Em terceiro, a complexidade destas iniciativas está relacionada à interação entre atores públicos, privados, sociedade civil e outros que participam de suas formulações e a quem se dirigem, como visto na Tabela 1 - Principais iniciativas globais de regulação de investimentos em agricultura. Enquanto o Voluntary Guidelines foca em posse da terra como uma responsabilidade dos Estados nacionais, e sua elaboração envolveu fortemente a sociedade civil e menos o setor privado, o PRAI foca em diretrizes para atores privados, os investidores, e foi formulado maiormente por organizações internacionais. 
Além disso, para Clapp, as iniciativas de regulação voluntária sobre terra e elementos a ela relacionados tendem a ter baixíssimas taxas de participação e adesão, assim como outras iniciativas de regulação de investimentos em geral. Porém, a não exigência por parte de tais iniciativas de assinatura ou adesão formal dos investidores dificulta saber ou medir exatamente a quantidade de investidores que os consideram em suas negociações (CLAPP, 2016). Quanto à adesão e implementação destas diretrizes, cabe pensar sobre o caso do Brasil. Segundo o VG, os Estados têm a responsabilidade de implementação, monitoramento e avaliação destas diretrizes a nível nacional, e o Brasil tem promovido, nos anos recentes, espaços para discussões internas sobre a implementação e monitoramento do VG domesticamente. França \& Marques (2017) apontam para a convergências de temas e prioridades entre as políticas públicas do Brasil, inclusive a política externa, e este documento. A correspondência entre as diretrizes e as ações do governo brasileiro dizem respeito ao acesso à terra, programas de redistribuição de terras e reordenamento agrário. Apesar deste e outros esforços particulares, as iniciativas de regulação dos investimentos em terra sofrem com baixas taxas de adesão e conformidade.

Em geral, as iniciativas de regulação voluntária se direcionam aos mais diversos participantes das transações, e buscam, de certa forma, convencê-los de que é proveitoso para os próprios agir de forma responsável, em respeito ao meio ambiente e questões sociais (CLAPP, 2016). Os investidores costumam aderir mais frequentemente a iniciativas voluntárias em casos em que estes vislumbram possibilidades de retornos da adesão, sejam estes financeiros ou ainda de outras naturezas; a título de exemplo, empresas que possuem como ponto forte de seus negócios a sustentabilidade social e ambiental, ou empresas preocupadas com as suas reputações, tendem a participar mais (CLAPP, 2016).

Conforme Jennifer Clapp (2016), isto pode ser observado nos casos de investimentos em agricultura, em que empresas mais preocupadas com as reputações de suas marcas, como grandes companhias já reconhecidas, se engajam mais em participar de iniciativas que promovem a sustentabilidade. Por outro 
lado, empresas com menos visibilidade e atores financeiros que não estão preocupados com suas reputações tendem a engajar-se menos com tais.

A participação de atores financeiros nos investimentos em elementos relacionados à terra tem crescido, conforme visto ao longo deste trabalho, como no mercado de futuro de commodities, produção de commodities, fundos de investimento, dentre outros. A complexidade dos mercados hoje, como os de terra e agricultura, e a pluralidade de atores ativos que apresentam, torna cada vez mais difícil atribuir determinados resultados de ações àqueles que os causaram. Tal complexidade aponta para a dificuldade de responsabilização dos investidores por suas ações no campo, que, por sua vez, contribui para que os investidores não estejam dispostos a mudar seus comportamentos de maneira voluntária (CLAPP, 2016).

O que Clapp (2014) chamou de "distanciamento" entre os investimentos e seus efeitos práticos explica como este aspecto representa um grande desafio para as iniciativas voluntárias. Este distanciamento possui ainda consequências para a ação política de resistência a estes investimentos, sobretudo para os movimentos do campo. O distanciamento dificulta a vinculação das consequências sociais e ecológicas às atividades de investimentos financeiros que os originaram e torna a ação política mais desafiadora. Esse processo está intrinsecamente associado ao papel da especulação financeira na apropriação de terras, à medida que o capital financeiro é cada vez mais atraído pelo ativo fixo da terra. Uma vez que não se pode identificar os responsáveis por determinadas consequências, como e a quem reclamar?

A adesão a estas iniciativas, que se colocam a favor dos investimentos "responsáveis", legitima discursivamente a ação de empresas que muitas vezes as adotam apenas formalmente, enquanto suas ações na prática seguem sendo feitas da mesma forma. A dificuldade de responsabilização de diversos atores envolvidos nestas dinâmicas, como visto, contribui ainda mais para que estas adesões se restrinjam somente aos discursos. 
Tais observações e argumentos são importantes para notar que estas iniciativas possuem pouca capacidade de reduzir os problemas sociais e ecológicos associados aos investimentos em terra e outros recursos, por limitações relacionadas às suas próprias naturezas e possibilidade de implementação. As regulações de natureza voluntária são simbólicas, mas não vinculantes e, em conclusão a estes argumentos, tendem a possibilitar poucas mudanças na prática. A insatisfação com o caráter voluntário dos instrumentos internacionais existentes para que empresas se comprometam a respeitar direitos humanos e direitos ambientais tem crescido no período recente. Observa-se que diversos movimentos têm se dedicado a demandar o estabelecimento de marcos legais alternativos para a regulação de investimentos e, quanto a isso, cabe destacar os esforços de certos grupos em auxiliar a negociação para a criação de um tratado vinculante no âmbito da ONU, para que tais direitos sejam respeitados ${ }^{11}$.

Esta dissertação, porém, mais que refletir sobre $\mathrm{o}$ potencial de transformação da prática destes documentos, busca aprofundar a crítica e, a partir dos referenciais teóricos desenvolvidos, evidenciar contradições mais profundas destas iniciativas. Defende-se que as iniciativas de regulação aqui analisadas, apesar de possuírem diferenças consideráveis, apresentam também semelhanças. Um ponto em comum fundamental é o tratamento dos investimentos em terra como inevitáveis e como essenciais para o desenvolvimento. De um lado, a ideia de inevitabilidade dos investimentos em terra e em agricultura indica que deve-se viver com tais, e implica o não questionamento dos processos históricos que os tornaram possíveis e os interesses que os movem. De outro lado, a defesa da importância dos investimentos baseia-se na ideia de que os investimentos - que resultam em land grabs - são práticas essenciais para a segurança alimentar mundial, e uma governança responsável dos recursos deve encorajar investimentos responsáveis. Pretende-se, na seção que segue, refletir sobre tais

${ }^{11}$ Para mais informações sobre as negociações para a criação de um tratado vinculante, ver $<$ https://fase.org.br/pt/informe-se/noticias/os-bastidores-das-negociacoes-na-onu-para-criar-umtratado-que-puna-empresas-que-violem-direitos-humanos/> Acesso em: 15 mai 2018. 
semelhanças entre as iniciativas e sobre as implicações desta forma de tratamento. A partir destas reflexões, busca-se refletir sobre a pergunta de partida desta dissertação.

\section{3.}

\section{A legitimação das apropriações de terras e a despolitização do debate}

As análises das iniciativas de regulação realizadas acima permitem afirmar que determinados elementos da formação discursiva da globalização neoliberal, que reificam o sistema econômico global dominado por grandes investidores e empresas transnacionais, estão presentes também nas iniciativas das organizações internacionais para tratar de land grabbing. As narrativas construídas por estas iniciativas associam os land grabs a uma dinâmica inevitável e irreversível da economia global. Apesar de apresentarem diferenças no tratamento de certos aspectos, este trabalho defende que tais iniciativas possuem semelhanças. Em comum entre elas está o tratamento dos investimentos em terras e outros recursos relacionados, tanto como inevitáveis, dentro de um contexto maior de globalização, com crescentes fluxos de capitais transnacionais, quanto como essenciais para o desenvolvimento.

As ideias de inevitabilidade e a defesa da importância dos investimentos para o desenvolvimento, porém, possuem implicações para o debate sobre o fenômeno, que são fundamentais para responder à pergunta de partida desta dissertação, às quais esta seção se dedica. Argumenta-se, sobretudo a partir destas ideias, que estas iniciativas legitimam as apropriações de terra que têm ocorrido em todo o mundo e contribuem para uma despolitização do debate sobre o fenômeno.

É importante ressaltar que, de maneira geral, entende-se que o tratamento oferecido por estas iniciativas aos land grabs é positiva e os investimentos são 
vistos como 'oportunidades' para o desenvolvimento, que devem ser aproveitadas. Esta formação discursiva da governança global dos investimentos em terra está presente em ambos os documentos analisados e ainda em vários outros, sobretudo os elaborados por atores do setor privado, como mencionado, ainda que haja diferença entre as abordagens. No PRAI, a 'necessidade dos investimentos' em terra e agricultura é justificada especialmente pela necessidade de se aumentar a produtividade da produção de pequenos agricultores, afim de alcançar crescimento econômico e redução da pobreza nos locais que recebem estes investimentos. Os investimentos "em nome da humanidade", como expresso anteriormente, passam pela modernização da agricultura para aumentar a eficiência das produções, em processos que "superem" as produções pequenas e as tradicionais, legitimando um modelo de desenvolvimento baseado no capital.

$\mathrm{O}$ VG, por sua vez, parece, em um primeiro momento, uma abordagem contraditória. Ao mesmo tempo que este documento ressalta a importância de elementos de visões de mundo dos camponeses e que reconhece diferentes significados da terra, direitos humanos, reformas redistributivas, dentre outros aspectos, também reforça a ideia de que os investimentos de larga escala em terra são importantes para a segurança alimentar mundial. Esta abordagem enfatiza que tanto os investimentos de origem pública quanto de origem privado são essenciais para melhorar a segurança alimentar, assim, ressalta a "necessidade" dos investimentos para o desenvolvimento. Nesse sentido, o VG se diferencia, em certa medida, do PRAI, porém, tampouco representa desafios às apropriações de terra em larga escala.

Em ambos os documentos, os investimentos que resultam em land grabs são práticas essenciais para melhorar a segurança alimentar, e identifica-se um discurso que enfatiza a "necessidade" dos investimentos para o desenvolvimento. A ideia de "necessidade" dos mercados está relacionada a formas de disciplinamento pelo qual se faz parecer que isto é necessário para o bem de todos, ainda que não o seja. Entende-se que, quando se admite a apropriação de terras em larga escala, o controle sobre os grandes territórios continua nas mãos de poucos e grandes. Ademais, cabe ressaltar que não basta reconhecer e proteger 
os interesses e preocupações dos pequenos produtores, mas priorizá-los e promovê-los (MCMICHAEL, 2016).

O aspecto inevitabilista, por sua vez, presente em tais iniciativas está relacionado a duas ideias interconectadas: em primeiro, à ideia de que não há alternativa para os investimentos, e, assim, que devemos viver com estes; em segundo, ao não questionamento dos processos históricos que tornaram tais investimentos possíveis e os interesses que os movem. $\mathrm{O}$ primeiro e segundo capítulos desta dissertação mostraram que os investimentos são, ao menos em parte, resultados de lutas, processos e estruturas históricas específicas, e, por isso, defende-se aqui que não devem ser pensados como inevitáveis ou irreversíveis. A corrida global por terras contemporânea foi possibilitada, em um primeiro momento, por processos históricos contraditórios, e tem sido marcada por disputas, relações de interesses e assimetria de poderes.

Diante disso, defende-se que, ao tratar os investimentos como dinâmicas inevitáveis, as iniciativas de regulação analisadas apresentam propostas de regulação e "transformação" que não questionam o contexto em que tais investimentos surgem, e oferecem respostas pontuais aos "problemas" que identificam. Tais propostas de "transformação", ao não questionarem a ordem vigente, podem ser compreendidas como úteis aos interesses dos que estão confortáveis com tal configuração. Trata-se de iniciativas que servem aos interesses do capital transnacional, cujo livre movimento e investimentos em recursos naturais mercantilizados é defendido.

Além disso, este trabalho argumenta que as narrativas construídas por estas organizações internacionais contribuem para uma despolitização do debate sobre land grabbing. $\mathrm{O}$ não questionamento dos contextos e processos históricos por trás dos investimentos, assim como a representação dos investimentos responsáveis como desejáveis, ideias que se combinam, estão ligados à forma como as narrativas contribuem para essa despolitização. A despolitização ocorre de diversas maneiras, como pela apresentação de problemas e respostas que colocam questões econômicas como questões técnicas que não podem ser 
contestadas politicamente. Identifica-se como representativo desta tentativa, o alarme quanto à necessidade de que hajam investimentos para aumentar a eficiência da produção de alimentos, afim de alimentar a humanidade, sobretudo por meio da divulgação de estudos realizados pela instituição e dados quantitativos. Estes estudos e dados apontam para a importância econômica destes investimentos, como faz o Banco Mundial em determinados relatórios recentes, que abordam estes investimentos, e até o PRAI.

A despolitização ocorre ainda pela forma com que tais narrativas contribuem para o processo identificado por Stephen Gill, em que se torna legitima a retirada do caráter democrático de determinadas políticas econômicas, sobretudo através do discurso da "participação" em áreas devidamente controladas e que não interfiram na política macroeconômica. A despolitização por meio das estratégias mencionadas faz parte de um conjunto maior de constrangimentos produtivos do novo constitucionalismo, que moldam a governança neoliberal da economia política e que dão bases para o poder do capital. A despolitização age de modo a conter contestações contra a ordem vigente, retirando de discussões democráticas as estratégias de política econômica, e representa uma tentativa de conferir legitimidade aos documentos.

A despolitização do debate é feita especialmente pelo PRAI, mas também em certa medida pelo VG. O VG considera políticas e ações que estão em conformidade com valores compartilhados pela sociedade civil, que respeite a agricultura de pequena escala, direitos de terras costumeiros e outros, desde que se mantenham as condições de reprodução do capital e a ordem permaneça estruturalmente idêntica. As iniciativas de regulação reconhecem que não deve haver prejuízos sociais associados aos investimentos, porém, as respostas oferecidas aos problemas pontuais encontrados por estas iniciativas funcionam dentro da mesma lógica capitalista de acumulação, que passa pela ressignificação da natureza, isto é, não representam desafios ou desvios a esta lógica.

Os documentos analisados identificam como problemas que levam a estes riscos, e que devem ser resolvidos, questões, como, por exemplo, a má 
governança dos Estados, e não as contradições inerentes ao sistema de produção no qual estão inseridos. A 'narrativa de crises' utilizada por estas regulações, em que se defende os investimentos como soluções para as múltiplas crises dos anos recentes, para a segurança alimentar mundial e para o combate à pobreza mundial, obscurecem a percepção de que estes problemas devem ser pensados enquanto resultados de contradições inerentes ao sistema capitalista e que land grabbing se expressa, em grande parte, como resultado destas crises, e não "solução".

Em vista do exposto, argumenta-se que os posicionamentos adotados por tais organizações internacionais terminam por legitimar os land grabs, apesar de toda a controvérsia e conflitos que os acompanham. Os investimentos são vistos com otimismo por ambas as iniciativas, desde que minimizados os 'riscos' em potencial e reais decorrentes destes. Cabe problematizar a quem este modelo de desenvolvimento serve e quem é afetado por ele.

A governança global dos investimentos em terra e em agricultura legitimam um modelo de desenvolvimento consistente com a civilização de mercado, que emerge com a expansão espacial e social do liberalismo, isto é, a globalização neoliberal. Este é, segundo Gill (2008), um movimento contraditório e um conjunto de práticas que envolvem, como visto, tanto ideologia, cultura e mitos, que são entendidos como uma ideologia ou mito do progresso capitalista, quanto um projeto de sociedade com visão de mundo 'ahistórica', economicista, materialista, individualista, imediatista e ecologicamente míope. As iniciativas de regulação dos land grabs podem ser compreendidas como parte deste processo, visto que, em tais, as terras, assim como outras diversas esferas da vida social, são submetidas à lógica de mercado, e nota-se um discurso neoliberal globalizante, consistente com a visão de mundo e com as prioridades do capital.

A análise anterior dos documentos evidenciou a existência de conflitos e contradições existentes por trás da tentativa de construção de consenso quanto à determinado modelo de desenvolvimento defendido em tais, e, ademais, evidenciou as estratégias utilizadas por tais organizações para defender seus posicionamentos. De maneira explícita ou implícita, os documentos são 
elaborados a partir de premissas ou mitos sobre desenvolvimento rural e agricultura, sobre globalização, sobre os próprios investimentos, que foram colocados em questão. As contradições destas diretrizes estão relacionadas também à própria estrutura histórica da ordem mundial vigente, em que predomina uma política de supremacia de um bloco histórico neoliberal, cujas ideias, que se fortalecem com a globalização neoliberal, se entrelaçam à governança global. A governança global da terra tem sido feita por instituições que têm agido de modo a possibilitar novos lugares para acumulação de capital e cujos discursos legitimam um modelo de desenvolvimento que privilegia os interesses do capital, prioriza produções de larga-escala, industriais, monoculturas e a base de combustíveis fósseis, que expulsa pessoas de suas terras e degrada o meio ambiente.

Outro efeito das iniciativas voluntárias de regulação de investimentos é que, tais, de modo geral, tendem a invisibilizar perspectivas alternativas para o desenvolvimento. Dentre as perspectivas analisadas, o PRAI se destaca pela narrativa de inevitabilidade e irreversibilidade dos investimentos presente em suas diretrizes, que tratam, por conseguinte, os investimentos como algo para o qual não há alternativa, em um movimento de despolitização do debate. Conforme visto, contudo, as perspectivas para o desenvolvimento rural informadas pelo neoliberalismo são envolvidas por conflitos e respondidas por movimentos de resistência. Posições que se contrapõem a estas abordagens dominantes se localizam em geral em movimentos sociais vindos do campo.

Organizações da sociedade civil têm atuado fortemente nos debates e negociações para o estabelecimento de instrumentos de governança global para os land grabs e alguns têm buscado espaços políticos de organizações internacionais, como a FAO, como forma de explicitar conflitos ligados ao modelo de desenvolvimento dominante. Os movimentos sociais de causas diversas, como a Via Campesina, ligadas a causas do mundo rural, têm desempenhado papel importante na política internacional de crítica ao neoliberalismo e na construção de propostas alternativas de desenvolvimento. A participação ativa destas organizações foi crucial para que diversos dos seus valores fossem incorporados 
ao VG. Todavia, é preciso assinalar que a incorporação de valores e reinvindicações destas visões de mundo parecem ocorrer sem se questionar o contexto histórico em que surgiu a atual configuração de forças e lógica dominante, que favorece a determinados grupos da sociedade. A sociedade civil global, entretanto, aponta o VG como um documento importante na luta contra o land grabbing (MARGULIS e PORTER, 2013).

Seguindo os pressupostos da teoria crítica, entende-se que a sociedade civil constitui não só o lugar em que as hegemonias são construídas, mas representam também atores com capacidade de transformação da ordem vigente. A partir destes pressupostos, esta dissertação sugere para a agenda de pesquisas futuras a análise do potencial de transformação de movimentos ligados ao campo como modelo alternativo à governança neoliberal de land grabbing. A Via Campesina, acadêmicos e ativistas têm defendido uma agenda de pesquisa sobre o conceito de soberania alimentar, potencial modelo alternativo para o desenvolvimento rural, formulado a partir de concepções de mundo dos camponeses. Além de representarem alternativas, portanto, os movimentos sociais ajudam a repolitizar o debate sobre land grabbing, mostrando que por trás do aparente consenso quanto à importância dos investimentos para a humanidade e a inevitabilidade destes, estes investimentos são marcados por conflitos, contradições sociais e ambientais. Conforme pressupostos da teoria crítica, é a partir dos conflitos e da contestação da ordem social que se vislumbra possibilidades de transformações. 


\section{5.}

\section{Considerações finais}

A presente dissertação nasceu do desejo de aprofundar a compreensão sobre o tratamento dado por organizações internacionais aos investimentos em terra e recursos relacionados, assim, ao fenômeno land grabbing, por meio de suas inciativas de regulação globais, e discutir os efeitos desta governança para as apropriações de terra. A teoria de influência marxista de David Harvey e a teoria crítica da disciplina de Relações Internacionais proveram as bases para este estudo.

Nesse sentido, cada um dos capítulos buscou cumprir com objetivos específicos que contribuíssem para a compreensão do tema desta dissertação. O segundo capítulo desta dissertação buscou introduzir os debates em torno de land grabbing e definir o fenômeno. Este é compreendido como apropriação de terras, que está diretamente ligada aos processos paralelos de acumulação por espoliação e reprodução ampliada do capital, conforme conceituação de David Harvey. O capítulo mostrou que a apropriação de terras, em particular a apropriação de terras por estrangeiros, é parte da história da humanidade e não representa um fenômeno completamente novo. Porém, a fase contemporânea da corrida por terras, associada às dinâmicas de expansão do capital, assim como as relações políticas e sociais deste novo período, possui particularidades. Transformações na ordem mundial, relacionadas à globalização neoliberal e outros processos como a financeirização da economia, contribuíram para um aumento nos casos de land grabs em todas as formas pelas quais se expressa. Além disso, o capítulo defendeu que a corrida foi possibilitada, em grande parte, por programas de reestruturação implementados pelo FMI e o Banco Mundial nos anos 1980 e 1990, e, nesse sentido, argumentou-se que land grabbing foi possibilitado por processos e contextos históricos específicos e que suas dinâmicas estão intimamente relacionadas a tais mudanças. 
O terceiro capítulo, por sua vez, buscou construir o marco teórico desta dissertação, para compreensão do que transformações do ponto de vista do capitalismo neoliberal representam para a governança global do fenômeno em consideração. Como base, foram adotadas as contribuições da chamada teoria crítica neogramsciana das Relações Internacionais, em particular determinados conceitos de Stephen Gill. Seguindo seus principais conceitos, ressaltou-se que a globalização neoliberal é marcada pela emergência de um bloco histórico neoliberal, que tem exercido uma política de supremacia pelos processos de neoliberalismo disciplinar, novo constitucionalismo, que são acompanhados pela civilização de mercado. Estes dois últimos conceitos permitem compreender como diversas esferas da vida têm sido ressignificadas e submetidas à lógica de mercado, como ocorre com a terra, transformada em mercadorias intercambiáveis, como parte de um projeto que visa dar as bases para o poder do capital. A governança global deste período de uma civilização de mercado é expressão das ideias neoliberais - mecanismos de governança, como de organizações e instituições internacionais, neste período expressam tais ideias neoliberais e possuem poder produtivo sobre os Estados, mercados e para conter movimentos de contestação. $\mathrm{O}$ acesso a uma natureza ressignificada tem sido garantido por um projeto político-jurídico que favorece o poder do capital. A governança global da terra se mostra ainda alinhada a tendências recentes da governança global, inclusive em seu formato, marcado por mecanismos flexíveis, baseados no automonitoramento e na adesão voluntária, características que tem favorecido o capital.

No quarto capítulo foram analisadas as iniciativas globais de governança dos investimentos em terra e itens relacionados, e, particularmente, a forma como os documentos PRAI e o VG tratam tais investimentos. De modo geral, as iniciativas de governança de investimentos os tratam como oportunidades de desenvolvimento que devem ser aproveitadas pelos locais que os recebem, mas sublinham, ao mesmo tempo, que se deve evitar externalidades negativas decorrentes destas práticas. Ambos os documentos analisados adotam posicionamentos favoráveis aos investimentos, justificados acima de tudo pela necessidade de acesso à terra para garantir a segurança alimentar do mundo. 
Enquanto o PRAI se mostra especialmente consistente com os interesses e visões de mundo dos detentores de capital, o VG considera determinados valores e significados das visões de mundo camponesas. Apesar disso, argumenta-se que ambos não oferecem desafios à lógica do capital, que mercantiliza diversas esferas da vida social. Buscou-se, assim, problematizar o tratamento oferecido por estas organizações às apropriações de terras, por meio de iniciativas que são expressões de ideias sobre um modelo de desenvolvimento, consistente com as ideias que favorecem aos interesses do capital. Mais que isso, este capítulo mostrou que as ideias de inevitabilidade e a defesa da importância dos investimentos para o desenvolvimento presentes nestes documentos são fundamentais para compreender as implicações destes posicionamentos para o fenômeno, isto é, os efeitos que estas iniciativas possuem.

A construção dos capítulos foi feita com vistas a responder à questão central para esta dissertação, seja esta "quais os efeitos das iniciativas para a regulação das apropriações de terra, elaboradas pelas organizações internacionais analisadas, sobre o fenômeno land grabbing?". A resposta a esta pergunta, em síntese, é que as organizações internacionais, por meio de suas iniciativas de governança da terra, legitimam os investimentos em larga escala em terras e outros itens associados a este recurso, como alimentos, água e florestas, isto é, legitimam as apropriações de terra, e contribuem para uma despolitização do debate sobre as apropriações.

As iniciativas de regulação de land grabbing analisadas, como discutido, apesar de suas sublinhadas diferenças, possuem em comum o tratamento dos investimentos em terras e outros recursos relacionados como inevitáveis e essenciais para o desenvolvimento. Estas abordagens legitimam um modelo de desenvolvimento informado por ideias neoliberais, apesar de toda a controvérsia e conflitos que os acompanham, vistos como oportunidades, desde que minimizados os 'riscos' em potencial e reais decorrentes destes. Os investimentos são tratados como fundamentais para alimentar a humanidade e os investimentos do setor privado são aliados essenciais para as agendas sociais e de desenvolvimento rural. Na governança global dos land grabs, predomina uma visão de mundo em que a 
terra é submetida à lógica mercadológica, assim, à lógica da civilização de mercado, centrada no capital, voltada aos interesses do grupo dominante e ecologicamente míope.

Além disso, argumenta-se que as iniciativas analisadas contribuem para uma despolitização do debate, associada às ideias quanto à importância dos investimentos e ao tratamento de tais, como se não houvesse alternativas a este modelo, ideias que se combinam. A despolitização do debate sobre land grabbing ocorre: pela colocação dos investimentos como uma solução para um problema técnico de falta de eficiência na produção de alimentos; pela proposição de soluções para amenizar problemas pontuais, que não problematizam as origens históricas e contradições que tornaram possíveis e intensificaram a corrida por terras nas últimas décadas. A forma como os investimentos em terra e outros recursos são tratados por estas organizações, nesse sentido, contribui para uma invisibilização de modelos alternativos de desenvolvimento. A despolitização ocorre ainda pelas medidas para contenção de contestações por meio do discurso da participação da sociedade civil na formulação de regulações, que reconhece determinados elementos de suas visões de mundo, sem que haja mudanças mais profundas.

Diante disso, cabe ressaltar que o percurso analítico desta dissertação mostrou que a corrida por terras é produto de contextos e processos históricos específicos, marcada por contradições e conflitos, portanto, por política. Os processos políticos, econômicos e sociais desenvolvidos no segundo e no terceiro capítulos desta dissertação correspondem à parte do contexto histórico em que as apropriações de terra surgiram e ao modo como estas práticas estão associadas a dinâmicas do sistema capitalista e transformações na ordem mundial. Apesar de não ser um fenômeno novo, defende-se que sua fase recente foi possibilitada por mudanças, inclusive estruturais, nas últimas décadas. Esta dissertação, dessa forma, contribuiu para repolitizar o debate sobre land grabbing, por meio de reflexões em perspectiva histórica e teóricas, pelas lentes de autores da Economia Política Internacional, como Harvey e Sassen, e pelas lentes da teoria crítica, para 
pensar a governança da terra a nível global, à luz de processos mais amplos de transformação da ordem mundial.

A análise, com vistas a compreender o fenômeno e a sua governança, não ocorreu entretanto, sem desafios. As múltiplas faces pelas quais se pode olhar para as apropriações de terra corresponderam a um dos maiores desafios encontrados por esta pesquisa. As apropriações de terra são compreendidas como uma necessidade do sistema capitalista de apresentar inovações para seguir acumulando capital, em dinâmicas que envolvem os simultâneos processos de acumulação por espoliação e reprodução ampliada. A corrida global atual por terras, que representa uma intensificação nas apropriações de terra, foi, em grande parte, viabilizada por reajustes estruturais do final do século XX e impulsionada por conjunturas específicas, como a de múltiplas crises, dentre outros fatores. Notou-se que a análise desta corrida pode ocorrer por múltiplos ângulos, que vão resultar em ênfases em fatores diferentes. A presente dissertação buscou, assim, pensar land grabbing em sua complexidade, a partir da Economia Política Internacional, e avançou no entendimento sobre o fenômeno e sua governança, mas a complexidade do tema aponta ainda para outras reflexões que se fazem necessárias e configuram temas para pesquisas futuras. Nesse sentido, foram identificadas como questões específicas, que merecem maior atenção, a atuação transnacional da sociedade civil e questões relacionadas à prática de desenvolvimento, em particular o debate sobre a participação na elaboração de políticas públicas como inclusão ou despolitização.

Deve-se reconhecer ainda que, neste trabalho, optou-se pela análise de iniciativas de regulação elaboradas por organizações internacionais formais, enquanto grande parte das regulações sobre investimentos em itens relacionados a agricultura e recursos naturais são elaborados por atores privados. A autoridade de atores privados em processos da economia e política globais constitui um ponto importante que este trabalho aponta para pesquisas futuras, por exemplo, como forma de entender as implicações da emergência de regulações direcionadas às atividades de atores privados, que são elaboradas pelos próprios atores, isto é, 
autorregulação, sobre diversos temas, como agricultura ou direitos humanos, frequentemente apoiados por organizações como a ONU.

As discussões presentes nesta dissertação tiveram como pano de fundo estudos de desenvolvimento. Cabe notar que este é um tema de pesquisa essencial para pensar países como o Brasil, onde a questão agrária é amplamente debatida por diversos autores há décadas, onde este também é um tema atual, visto que se encontram atualmente em debate e tramitação projetos de leis e outras medidas jurídicas que propõem mudanças no tratamento dos investimentos estrangeiros no país. Land grabbing representa um ponto importante para compreensão de dinâmicas e transformações que dizem respeito à relação entre o capital e a produção, transformações agrárias nos últimos anos, como mudanças no uso e no significado da terra, dentre outros aspectos que permearam esta dissertação. 
6.

\section{Referências bibliográficas}

AMOORE, L. et al. Overturning 'Globalisation': Resisting the teleological, reclaiming the 'political'. New Political Economy, vol. 2, n. 1, p. 179-195, 1997.

ARAGÃO, D. M. C. D. Responsabilidade como Legitimação: Capital Transnacional e Governança Global na Organização das Nações Unidas. Tese de Doutorado, Rio de Janeiro, 2010.

ARAGÃO, D. M. D.; SANTOS, T. M. D. A governança global do desenvolvimento e a despolitização do land grabbing: "there is no alternative"? Estudos Internacionais, vol. 5, n.2, p. 57-73, 2017.

ARENDT, H. Origens do totalitarismo. São Paulo: Schwarcz, 1998.

BM\&FBOVESPA - CVM. Mercado de Derivativos no Brasil: Conceitos, Produtos e Operações. Rio de Janeiro: Comissão de Valores Mobiliários, 2015. Disponivel em: <http://www.portaldoinvestidor.gov.br/portaldoinvestidor/export/sites/portaldoinv estidor/publicacao/Livro/Livro-TOPDerivativos.pdf>. Acesso em: 23 mar. 2018.

BORRAS JR, S. M.; MCMICHAEL, P.; SCOONES, I. The politics of biofuels, land and agrarian change: editors' introduction. Journal of Peasant Studies, vol. 37, n. 4, p. 575-592, 2010.

BORRAS JR, S.; FRANCO, J. From Threat to Opportunity? Problems with the Idea of a "Code of Conduct" for Land- Grabbing. Yale Human Rights and Development Journal, vol. 13, n. 2, p. 507-523, 2010.

BORRAS JR., S. et al. Land grabbing and global capitalist accumulation: key features in Latin America. Canadian Journal of Development Studies/Revue canadienne d'études du développement, vol. 33, n. 4, p. 402-216, 2012. 
BORRAS, S. M. et al. The rise of flex crops and commodities: implications for research. The Journal of Peasant Studies, vol. 43, n.1, p. 93-115, 2015.

BORRAS, S. M.; FRANCO, J. C.; WANG, C. The Challenge of Global Governance of Land Grabbing: Changing International Agricultural Context and Competing Political Views and Strategies. Globalizations, vol. 10, n.1, 161-179, 2013.

BOTELHO, M. L. Teoria da Crise em David Harvey. Revista Continentes, p. 66111, 2014. Disponível em: http://www.revistacontinentes.com.br/continentes/index.php/continentes/article/vi ew/40/40 [Acesso em: 03 ago. 2018]

CAMARGO, A. D. S. Globalização e Hegemonia nas Relações Internacionais: O caso da Via Campesina por uma perspectiva gramsciana. Dissertação de Mestrado, São Paulo, 2013.

CLAPP, J. Distant agricultural landscapes. Sustainability Science, vol. 10, p. 305-216, 2015.

CLAPP, J. Financialization, Distance and Global Food Politics. The Journal of Peasant Studies, vol. 41, n.5, p. 797-814, 2014.

CLAPP, J. Responsibility to the rescue? Governing private financial investment in global agriculture. Agriculture and Human Values, 2016.

CLAPP, J.; HELLEINER, E. Troubled futures? The global food crisis and the politics of agricultural derivatives regulation. Review of International Political Economy, vol. 19, n. 2, p. 181-207, 2012.

COX, R. Social Forces, States and World Orders: Beyond International Relations Theory. Revista Millenium: Journal of International Studies, vol. 10, n. 2, p. 126-151, 1981. 
COX, R. Gramsci, Hegemonia e Relações Internacionais: Um ensaio sobre o método. In: GILL, S. Gramsci, materialismo histórico e relações internacionais. Rio de Janeiro: UFRJ, p. 101-123, 2007.

CSM4CFS. Synthesis Report on Civil Society experiences regarding use and implementation of the Tenure Guidelines and the challenge of monitoring CFS decisions. Rome. 2016. Disponível em: <http://www.csm4cfs.org/wpcontent/uploads/2016/09/CSM-Monitoring-Report-VGGT-final1_EN-1.pdf>. Acesso em: 26 abr. 2018.

CUTLER, A. C. New constitutionalism and the commodity form of global capitalism. In: GILL, S.; CUTLER, A. C. New Constitutionalism and World Order. Cambridge: Cambridge University Press, 2014.

EDELMAN, M.; OYA, C.; BORRAS JR., S. Global Land Grabs: historical processes, theoretical and methodological implications and current trajectories. Third World Quarterly, vol. 34, n. 9, p. 1517-1531, 2013.

EPSTEIN, G. A. Introduction: Financialization and the World Economy. In: (ED.), G. A. E. Financialization and the World Economy. Cheltenham: Edward Elgar Publishing, 2005.

FAIRBAIRN, M. Like gold with yield': evolving intersections between farmland and finance. The Journal of Peasant Studies, vol. 41, n.5, p. 777-795, 2014.

FAIRHEAD, J.; LEACH, M.; SCOONES, I. Green Grabbing: a new appropriation of nature? The Journal of Peasant Studies, vol. 39, n. 2, p. 237$261,2012$.

FAO. Voluntary Guidelines on the Responsible Governance of Tenure of Land, Fisheries and Forests in the Context of National Food Security. Roma. 2012. Disponível em: <http://www.fao.org/docrep/016/i2801e/i2801e.pdf>. Acesso em: 10 nov. 2017. 
FAO, IFAD, UNCTAD, WORLD BANK GROUP. Principles for Responsible Agricultural Investment that Respects Rights, Livelihoods and Resources. 2010. Disponível em: <http://siteresources.worldbank.org/INTARD/2145741111138388661/22453321/Principles_Extended.pdf>. Acesso em: 10 nov. 2017.

FRANÇA, C. G. D.; MARQUES, V. P. M. D. A. O Brasil e a implementação das Diretrizes Voluntárias da Governança da Terra, da Pesca e dos Recursos Florestais: aspectos da experiência recente. In: MALUF, R. S.; FLEXOR, G.; (ORGS.) Questões agrárias, agrícolas e rurais: conjunturas e políticas públicas. Rio de Janeiro: E-papers Serviços Editoriais, 2017.

GILL, S. Power and Resistance in the New World Order. New York: Palgrave Macmillan, 2008.

GILL, S. Market civilization, new constitutionalism and world order. In: GILL, S.; CUTLER, A. C. New Constitutionalism and World Order. Cambridge: Cambridge University Press, p. 29-44, 2014.

GRAIN. The global farmland grab in 2016: how big? how bad? 2016. Disponível em: <https://www.grain.org/article/entries/5492-the-global-farmlandgrab-in-2016-how-big-how-bad>. Acesso em: 07 dez. 2017.

HALE, T.; HELD, D. Handbook of Transnational Governance: Institutions and Innovations. Cambridge: Polity Press, 2011.

HALL, D. Primitive Accumulation, Accumulation by Dispossession and the Global Land Grab. Third World Quarterly, vol. 34, n. 9, p. 1582-1604, 2013.

HARVEY, D. O Enigma do Capital e as Crises do Capitalismo. São Paulo: Boitempo, 2011.

HARVEY, D. O Novo Imperialismo. São Paulo: Edições Loyola, 2004a.

HARVEY, D. O "Novo" Imperialismo: acumulação por espoliação. Socialist Register, p. 95-126, 2004 b. 
HARVEY, D. Seventeen Contradictions and the End of Capitalism. Nova Iorque: Oxford University Press, 2014.

LAND MATRIX. The Land Matrix Global Observatory. The Land Matrix Global Observatory, 2018. Disponivel em: <http://www.landmatrix.org/en>. Acesso em: 26 mar 2018.

LUXEMBURGO, R. A Acumulação do Capital: Estudo sobre a Interpretação Econômica do Imperialismo. Rio de Janeiro: Zahar Editores, 1970.

MARGULIS, M. Emergent Global Land Governance. In: SETO, K. C.; REENBERG, A. Rethinking Global Land Use in an Urban Era. Cambridge: MIT University Press, p. 183-200, 2014.

MARGULIS, M. E.; MCKEON, N.; BORRAS JR., S. M. Land Grabbing and Global Governance: Critical Perspectives. Globalizations, vol. 10, n. 1, p. 1-23, 2013.

MARGULIS, M. E.; PORTER, T. Governing the Global Land Grab: Multipolarity, Ideas, and Complexity in Transnational Governance. Globalizations, vol. 10, n. 1, p. 65-86, 2013.

MCKEON, N. 'One Does Not Sell the Land Upon Which the People Walk': Land Grabbing, Transnational Rural Social Movements, and Global Governance. Globalizations, vol. 10, n. 1, p. 105-122, 2013.

MCMICHAEL, P. A food regime analysis of the 'world food crisis'. Agriculture Human Values, Springer, vol. 26, p. 281-295, 2009.

MCMICHAEL, P. Food Security, Land, and Development. In: GRUGEL, J.; HAMMETT, D.; (EDS) The Palgrave Handbook of International Development. Londres: Palgrave Mcmillan: Springer Nature, p. 671-694, 2016. MCMICHAEL, P. Global Food Politics. In: MAGDOFF, F., et al. Hungry for Profit. Nova Iorque: Monthly Review Press, p. 125-143, 2000. 
MCMICHAEL, P. The land grab and corporate food regime restructuring. Journal of Peasant Studies, vol. 39, n. 3-4, p. 681-701, 2012.

MCMICHAEL, P. The Land Question in the Food Sovereignty Project. Globalizations, vol. 12, n. 4, p. 434-451, 2015.

NOLTE, K.; CHAMBERLAIN, W.; GIGER, M. International Land Deals for Agriculture: Fresh insights from the Land Matrix: Analytical Report II. 2016. Disponível em: https://landmatrix.org/media/filer_public/ab/c8/abc8b5639d74-4a47-9548-cb59e4809b4e/land_matrix_2016_analytical_report_draft_ii.pdf [Acesso em: 03 mar. 2018].

OYA, C. Methodological reflections on 'land grab' databases and the 'land grab' literature 'rush'. The Journal of Peasants Studies, vol. 40, n. 3, p. 503-520, 2013.

OYA, C. The World Development Report 2008: inconsistencies, silences, and the myth of 'win-win' scenarios. The Journal of Peasant Studies, vol. 36, n. 3, p. 593-601, 2009.

PEREIRA, J. M. M. Neoliberalismo, políticas de terra e reforma agrária de mercado na América Latina. In: PEREIRA, J. M. M.; SAUER, S. Capturando a Terra: Banco Mundial, políticas fundiárias neoliberais e reforma agrária de mercado. São Paulo: Expressão Popular, p. 13-48, 2006.

PEREIRA, J. M. M. O Banco Mundial como ator político, intelectual e financeiro (1944-2008). Tese de Doutorado, Niterói, 2009.

PEREIRA, J. M. M. Saber, poder e indução política: Banco Mundial, ator intelectual. jornalggn.com.br, Rio de Janeiro, 05 dez. 2017. Disponivel em: <http://www.vermelho.org.br/noticia/305125-1>. Acesso em: 10 abr. 2018.

ROSENAU, J. N. Governance, Order, and Change in World Politics. In: ROSENAU, J. N. Governance Without Government: Order and Change in 
World Politics. Cambridge: The Press Syndicate of the University of Cambridge, p. 1-29, 1992.

SASSEN, S. A Savage Sorting of Winners and Losers: Contemporary Versions of Primitive Accumulation. Globalizations, vol. 7, n. 1, p. 23-50, 2010.

SASSEN, S. Expulsões: Brutalidade e Complexidade na Economia Global. Rio de Janeiro: Paz e Terra, 2016.

SASSEN, S. Land Grabs Today: Feeding the Disassembling of National Territory. Globalizations, vol. 10, n. 1, p. 25-46, 2013.

SAUER, S.; BORRAS JR., S. 'LAND GRABBING' E 'GREEN GRABBING': Uma leitura da 'corrida na produção acadêmica' sobre a apropriação global de terras. CAMPO-TERRITÓRIO: revista de geografia agrária, n. Especial, p. 642, 2016.

SAUER, S.; LEITE, S. Expansão Agrícola, Preços e Apropriação de Terra Por Estrangeiros no Brasil. Revista de Economia e Sociologia Rural - RESR, p. 503-524, 2012.

SHUTTER, O. D. How not to think of land-grabbing: three critiques of largescale investments in farmland. The Journal of Peasant Studies, vol. 38, n. 2, p. 249-279, 2011.

SPARKE, M. Introducing globalization: ties, tensions, and uneven integration. Chichester: John Wiley \& Sons, 2013.

TNI. The Global Land Grab: a primer. TNI Agrarian Justice Programme, 2013. Disponível em: <https://www.tni.org/files/download/landgrabbingprimerfeb2013.pdf>. Acesso em: 15 nov. 2017.

WEISS, T. G.; WILKINSON, R. International Organization and Global Governance: What Matter and Why. In: WEISS, T. G.; WILKINSON, R. International Organization and Global Governance. London \& New York: Routledge, p. 3-18, 2014. 
WHITE, B. et al. The new enclosures: critical perspectives on corporate land deals. The Journal of Peasant Studies, vol. 39, n. 3-4, p. 619-647, 2012.

WHITE, B.; DASGUPTA, A. Agrofuels capitalism: a view from political economy. The Journal of Peasant Studies, vol. 37, n.4, p. 593-607, 2010.

WILKINSON, J.; REYDON, B.; SABBATO, A. D. Concentration and foreign ownership of land in Brazil in the context of global land grabbing. Canadian Journal of Development Studies, vol. 33, n. 4, p. 417-438, 2012. 